\author{
UNIVERSIDADE DE SÃO PAULO \\ FACULDADE DE MEDICINA DE RIBEIRÃO PRETO \\ DEPARTAMENTO DE FARMACOLOGIA
}

JESSICA ROSA

Os efeitos sustentados do estresse agudo sobre o processo de extinção da memória de medo condicionado contextual:

participação dos receptores glicocorticoides no córtex pré-frontal

Ribeirão Preto 


\section{JESSICA ROSA}

Os efeitos sustentados do estresse agudo sobre o processo de extinção da memória de medo condicionado contextual:

participação dos receptores glicocorticoides no córtex pré-frontal

Versão corrigida. A versão original encontra-se disponível tanto na Biblioteca da Unidade que aloja o Programa, quanto na Biblioteca Digital de Teses e Dissertações da USP (BDTD)

Tese apresentada à Faculdade de Medicina de Ribeirão Preto da Universidade de São Paulo como requisito parcial para obtenção de grau de Doutor.

Área de Concentração: Farmacologia.

Orientador: Professor Doutor Leonardo Resstel Barbosa de Moraes

Ribeirão Preto 
Autorizo a reprodução e divulgação total ou parcial deste trabalho, por qualquer meio convencional ou eletrônico, para fins de estudo e pesquisa, desde que citada a fonte.

\section{DADOS DE CATALOGAÇÃO}

Rosa, Jessica

Os efeitos sustentados do estresse agudo sobre o processo de extinção da memória de medo condicionado contextual: participação dos receptores glicocorticoides no córtex pré-frontal. Ribeirão Preto, 2019.

148 p.: il.;30 cm

Tese de Doutorado apresentada à Faculdade de Medicina de Ribeirão Preto/USP. Área de Concentração: Farmacologia.

Orientador: Professor Doutor Leonardo Resstel Barbosa de Moraes.

1. Extinção da memória de medo condicionado contextual. 2. Estresse agudo. 3. PTSD. 4. Córtex pré-frontal. 5. Receptores glicocorticoides. 6. Receptores mineralocorticoides. 
FOLHA DE AVALIAÇÃO

JESSICA ROSA

Os efeitos sustentados do estresse agudo sobre o processo de extinção da memória de medo condicionado contextual:

Participação dos receptores glicocorticoides no córtex pré-frontal

Tese apresentada à faculdade de Medicina de Ribeirão Preto da Universidade de São Paulo como requisito parcial para obtenção de grau de Doutor.

Área de Concentração: Farmacologia.

Orientador: Professor Doutor Leonardo Resstel Barbosa de Moraes

Aprovada em 07 de março de 2019.

\section{COMISSÃO EXAMINADORA:}

Prof. Dr. Leonardo Resstel Barbosa Moraes

(Presidente - FMRP - USP)

Prof. Dr. Francisco Silveira Guimarães

(Titular FMRP - USP)

Prof. Dr. Antonio de Pádua Carobrez (Titular UFSC - Externo)

Prof. Dr. Norberto Garcia Cairasco

(Titular FMRP - USP)

Prof. Dr. Leandro José Bertoglio (Titular UFSC - Externo)
Parecer: Aprovada

Parecer: Aprovada

Parecer: Aprovada

Parecer: Aprovada

Parecer: Aprovada 
A presente Tese de Doutorado é resultado de um projeto de investigação científica realizado no Laboratório de Neurofarmacologia do Departamento de Farmacologia da Faculdade de Medicina de Ribeirão Preto - Universidade de São Paulo com auxílio financeiro da Fundação de Amparo à Pesquisa do Estado de São Paulo (FAPESP Processos 2015/11800-3 e 2017/24025-3), Coordenação de Aperfeiçoamento de Pessoal de Nível Superior (CAPES), Concelho Nacional de Desenvolvimento Científico e Tecnológico (CNPq), e Fundação de Apoio ao Ensino, Pesquisa e Assistência do Hospital das Clínicas da Faculdade de Medicina de Ribeirão Preto da Universidade de São Paulo (FAEPA). 
A Maria Leofrísio Urbano Francisco (in memoriam), Dona Maria pipoqueira, escritora, poetisa. 


\section{AGRADECIMENTOS}

Ao Professor Dr. Leonardo B. M. Resstel, por confiar em mim e no meu trabalho.

Aos colegas do laboratório de Neurofarmacologia da USP Ribeirão Preto, em especial a Laura Camargo, Daniela Lescano e Leandro Antero, Teophanes Barbosa Moraes Neto, Egidi Mayara Firmino Silva, Ana Luiza Terzian, Anna Bárbara Borges de Assis, Luana Domingos Barreto, Luciana Bärg Kuntze, Davi Campos La Gatta, Gabriela B. Luiz.

A Fundação de Amparo à Pesquisa do Estado de São Paulo FAPESP - Processos 2015/11800-3 e 2017/24025-3 - pelo financiamento do projeto de pesquisa, por ser uma agência de excelência, que respeita e apoia o pós-graduando. Ser comtemplada com a Bolsa de Doutorado pela FAPESP fez toda a diferença em minha formação. Obrigada!

A Coordenação de Aperfeiçoamento de Pessoal de Nível Superior (CAPES) pelo financiamento inicial de minha pesquisa, no começo de meu doutorado.

A Fundação de Apoio ao Ensino, Pesquisa e Assistência (FAEPA).

A Universidade de São Paulo e a todos os seus Professores e funcionários, em especial aos do Departamento de Farmacologia da Faculdade de Medicina.

Aos membros da banca examinadora deste Tese, pela paciência, disponibilidade e contribuições.

A todos que de alguma maneira contribuíram para o desenvolvimento desta Tese, em especial ao Carlos Alberto Aguiar da Silva.

A minha família, em especial a minha mãe e melhor amiga, Eduvirges Goreti da Rosa. E ao meu irmão Felipe Rosa Frota.

Ao meu noivo e melhor amigo Izaque de Sousa Maciel. 
Aquele que é infinitamente superior a tudo!

Gratidão, por todo o aprendizado que este Doutorado me proporcionou.

Gratidão pela dádiva da vida, por fazer de mim uma eterna aprendiza. 
"Nada somos além daquilo que recordamos." Iván Izquierdo 


\section{RESUMO}

Rosa J. Os efeitos sustentados do estresse agudo sobre o processo de extinção da memória de medo condicionado contextual: participação dos receptores glicocorticoides no córtex pré-frontal [Tese]. São Paulo: Faculdade de Medicina de Ribeirão Preto, Departamento de Farmacologia, Universidade de São Paulo; 2019.

O estresse pode ser um fator de predisposição para o desenvolvimento de transtornos psiquiátricos, como o transtorno de estresse pós-traumático (do inglês posttraumatic stress disorder; PTSD). E tem sido demonstrado que o processo de extinção da memória de medo parece estar prejudicado em alguns pacientes que apresentam este transtorno. A porção ventromedial do córtex pré-frontal (CPFvm) tem sido considerado como um importante sítio envolvido nas respostas cardiovasculares, neuroendócrinas e comportamentais frente a eventos aversivos, e onde há uma rica expressão de receptores glicocorticoides e mineralocorticoides, sugerindo que a regulação das respostas ao estresse pelo CPFvm pode ser mediada pelo feedback do cortisol em humanos, ou da corticosterona em roedores. Contudo, as consequências do estresse agudo ou do papel desempenhado pelos receptores de glicocorticoides e mineralocorticoides no CPFvm, para o aprendizado da extinção, ainda são pouco conhecidos. Esta pesquisa científica teve como objetivo investigar o papel do estresse agudo e dos receptores mineralocorticoides e glicocorticoides presentes no CPFvm, no processo de extinção de memória aversiva. Para desenvolver este estudo, ratos Wistar foram submetidos à cirurgia estereotáxica para implante de cânulas-guia nas regiões pré-límbica (PL) ou infralímbica (IL) do CPFvm, com o propósito de viabilizar a administração intra-cérebro dos compostos farmacológicos, ou de seus veículos, nas regiões alvo deste estudo. Após 4 dias de recuperação os animais foram divididos em 2 grupos: 1) animais expostos a uma única sessão de estresse por restrição, em tubos de inox ventilados, por um período de 1 hora e 2) animais que permaneceram no biotério em condições habituais (animais não estressados). No sétimo dia após o procedimento de estresse por restrição, ambos os grupos de animais, estressados e não estressados foram submetidos à uma sessão de treino na tarefa comportamental de medo condicionado ao contexto (MCC; 4 estímulos elétricos de 0,85 mA/1s). Após $24 \mathrm{~h}$ os animais foram expostos ao mesmo aparato, na ausência do estímulo elétrico, durante 20 min (sessão de extinção). Para retenção da memória de extinção (sessão 
de teste; 24 h após a sessão de extinção) os animais foram novamente expostos à caixa de condicionamento, durante $5 \mathrm{~min}$, na ausência de estímulo elétrico. Nas sessões de treino, extinção e teste foi mensurada a resposta de Freezing do animal (imobilidade total do animal, exceto os movimentos respiratórios) como medida de memória. Nossos resultados demonstraram que os animais submetidos ao estresse agudo apresentaram um aumento na expressão do medo condicionado ao contexto, contudo, assim como os animais não estressados, estes foram capazes de adquirir a memória de extinção ao longo da sessão. Porém, 24h após, quando ambos os grupos foram reexpostos ao contexto aversivo para a sessão de teste da retenção da memória de extinção, o grupo estressado apresentou uma recuperação da memória de extinção significativamente menor do que o grupo não estressado. Isto sugere que o estresse agudo não prejudica a aquisição, mas promove um déficit na consolidação da memória de extinção do medo condicionado contextual. Além disso, o antagonista do receptor para glicocorticoides (Mifeprostone ou RU486; 10 ng/lado) microinjetado nas porções PL ou IL do CPFvm, imediatamente após a sessão de extinção da memória aversiva, atenuou o déficit na consolidação da extinção apresentado pelos animais estressados, sem apresentar efeito sobre os animais não estressados. Contudo, o antagonista de receptores para mineralocorticoides (Oxprenoato de potássio ou RU 28318; na dose de 150 ng/lado), microinjetado na região IL do CPFvm não mostrou efeito sobre o déficit de extinção promovido pelo estresse agudo. Deste modo, nossos resultados revelam que uma breve e única exposição a um evento estressor resulta em déficit na consolidação da extinção da memória de medo contextual, por meio da ativação de receptores para glicocorticoides presentes no CPFvm.

Palavras-chave: extinção da memória de medo condicionado contextual, estresse agudo, PTSD, córtex pré-frontal, receptores glicocorticoides, receptores mineralocorticoides 


\begin{abstract}
Rosa J. The long-lasting effects of acute stress on the contextual extinction memory: Participation of glucocorticoid receptors in the prefrontal cortex [Tese]. São Paulo: Faculdade de Medicina de Ribeirão Preto, Departamento de Farmacologia, Universidade de São Paulo; 2019.
\end{abstract}

It has been proposed that a brief exposure to stress leads to deficits in fear memory extinction. Interestingly, extinction learning can be used as treatment for phobia or posttraumatic stress disorder (PTSD). However, further evidence is still necessary to completely understand the memory extinction process. One brain region highly involved in memory formation and extinction is the prefrontal cortex (PFC). Its ventromedial portion (VMPFC) is widely associated with neuroendocrine and behavior responses during stressful situations. Additionally, there is a high expression of glucocorticoid receptors in this area. Thus, the current study investigated the effects of acute stress, along with the role of glucocorticoid receptors present in the VmPFC in the memory extinction learning. To this aim male Wistar rats with infusion cannulae stereotaxically implanted in the prelimbic (PL) or infralimbic (IL) regions of the vmPFC were divided in two independent groups: 1) Stressed group (1h restraint stress); 2) Control group (no stress). On the seventy day, both groups were exposed to extinction of contextual fear conditioning protocol. Our results demonstrated that the both groups were able to extinct fear responses over the time during extinction session, but only the stressed group showed an increase of contextual fear conditioning expression. Interestingly, on the next day, the stressed group demonstrated significantly less extinction retrieval than not-stressed group. This suggests that acute stress do not impaired acquisition but promotes a deficit in extinction fear memory consolidation. Moreover, the glucocorticoid receptor antagonist (RU 486; 10ng/side) microinjected into the PL or IL, immediately after the extinction session, attenuated such deficit in stressed animals. On the other hand, the MRs antagonist (RU 28318) at a dose of 150ng/100nl/side microinject to the IL immediately after the extinction session didn't attenuate such deficit in stressed animals. Our results unveiled that a brief and single stress episode prior to contextual fear conditioning leads to extinction deficit. Furthermore, our data suggests that glucocorticoid receptors in vmPFC are necessary for the impairing extinction memory promoted by acute stress. This study is important 
to characterizing how stress affects memory extinction and could offer new insights about the extinction-based exposure therapy.

Keywords: contextual fear conditioning extinction, acute stress, PTSD, prefrontal cortex, glucocorticoid receptor, mineralocorticoid receptor. 


\section{LISTA DE ABREVIATURAS}

$\mu \mathrm{l}:$ microlitros

ACTH: do inglês adrenocorticotrofic hormone; hormônio adrenocorticotrópico.

AP: antero-posterior

CPF: córtex pré-frontal

CPFvm: córtex pré-frontal ventromedial

DV: dorso-ventral

EPM: erro padrão da média

ER: Estresse por restrição.

FC: frequência cardíaca

FDA: Food and drug administration

G: gouge

g: gramas

GAPDH: (Glyceraldehyde 3-phosphate dehydrogenase) mA: miliampère

GR: do inglês glicocortioid receptor; receptor glicocorticoide

h: horas

HLC: hormônio liberador de corticotrofina

HPA: hipotálamo-hipófise-adrenal

i.m.: intramuscular

i.p.: intraperitoneal

IL: infra-límbica (região do córtex pré-frontal ventromedial)

kg: kilograma

LL: latero-lateral

MCC: medo condicionado ao contexto ou medo condicionado contextual mg: miligramas

min: minutos

ml: mililitros

MR: do inglês mineralocorticoid receptor; Receptor mineralocorticoide

ng: nanogramas

nl: nanolitros

${ }^{\circ} \mathrm{C}$ : graus célsius

P: nível descritivo ou probabilidade de significância 
PAM: pressão arterial média

PL: pré-limbica (região do córtex pré-frontal ventromedial)

PTSD: do inglês post-traumatic stress disorder; trastorno de estresse pós-traumático REC: resposta emocional condicionada

rpm: rotações por minuto

s: segundos

TC: temperatura cutânea

USP: universidade de São Paulo

WB: Western Blotting 


\section{LISTA DE FIGURAS}

Figura 1. Efeito sustentado do estresse agudo sobre o perfil de extinção da memória de medo condicionado ao contexto.

Figura 2. Efeito da administração do antagonista de receptores para glicocorticoides na porção IL do CPFvm sobre a consolidação da extinção de memória aversiva em animais estressados e não estressados.

Figura 3. Efeito da administração do antagonista de receptores para glicocorticoides na porção PL do CPFvm sobre a consolidação da extinção de memória aversiva em animais estressados e não estressados.

Figura 4. Efeito da administração do antagonista de receptores para mineralocortioides na porção IL do CPFvm sobre a consolidação da extinção de memória aversiva em animais estressados e não estressados 60

Figura 5. Perfil de extinção da memória de medo condicionado ao contexto e da retenção da memória de extinção em animais estressados e não estressados submetidos ao protocolo experimental 4, sendo a sessão de extinção realizada durante o pico do ciclo circadiano de corticosterona dos animais (período vespertino)

Figura 6. Perfil de extinção da memória de medo condicionado em animais estressados e não estressados (estudo piloto).

Figura 7. Protocolo experimental para aferição das respostas comportamentais e autonômicas. .78

Figura 8. Perfil de extinção da memória de medo condicionado ao contexto e da retenção da memória de extinção em animais estressados e não estressados submetidos ao protocolo experimental 1 (descrito no item 3.14.1, materiais e métodos) 
Figura 9. Perfil de extinção da memória de medo condicionado ao contexto em animais estressados e não estressados (estudo piloto- ensaio 1). 103

Figura 10. Perfil de extinção da memória de medo condicionado em animais estressados e não estressados (estudo piloto - ensaio 2) 105

Figura 11. Perfil de extinção da memória de medo condicionado ao contexto em animais estressados e não estressados mantidos em regime de isolamento (estudo piloto - ensaio 3). 107

Figura 12. Perfil de extinção da memória de medo condicionado ao contexto e da retenção da memória de extinção em animais estressados e não estressados (estudo piloto - ensaio 4) 109 


\section{SUMÁRIO}

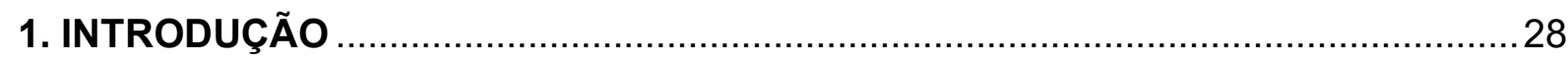

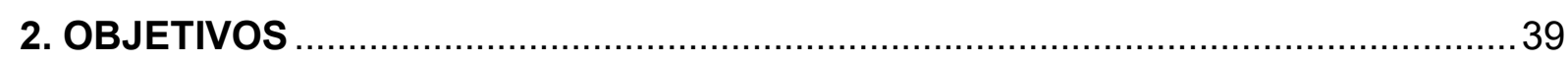

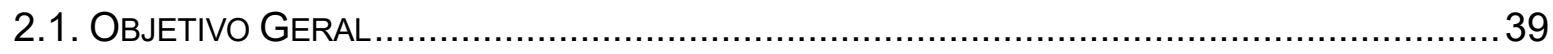

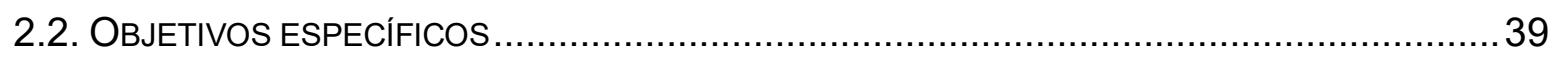

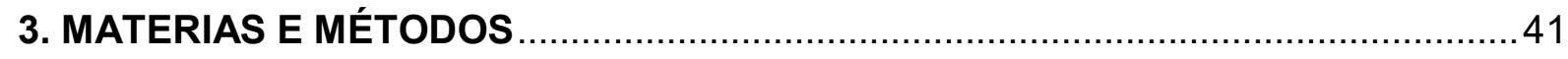

3.8. ANÁLISE HISTOLÓGICA DO POSICIONAMENTO DAS CÂNULAS-GUIA ...............................45

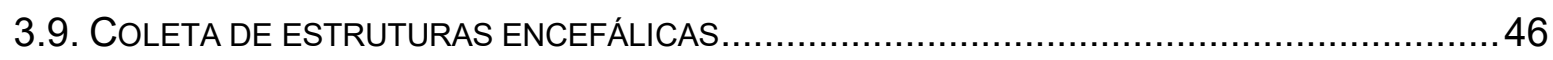

3.10. Coleta de AMOSTRAS DE SANGUE PARA DOSAGEM DE CONCENTRAÇÕES SÉRICAS DE

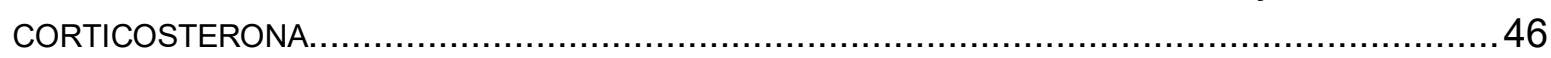

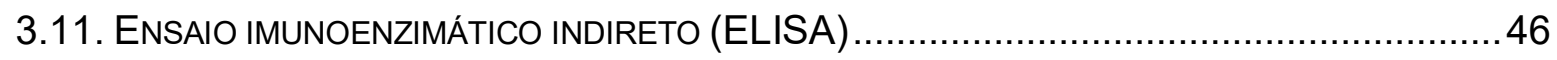

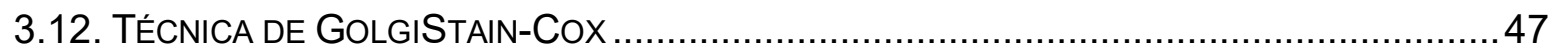

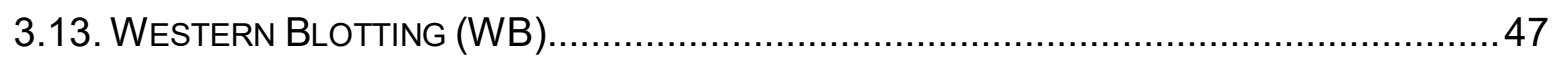

3.14. PROTOCOLOS EXPERIMENTAIS....................................................................... 48

3.14.1. Protocolo experimental 1: O papel do estresse agudo no processo de extinção da memória de condicionamento aversivo: Perfil de extinção da memória de medo condicionado ao contexto em animais estressados e não estressados, submetidos a um estresse agudo inescapável prévio ao MCC em um protocolo de 9 dias com treino de 4 choques de $0,85 \mathrm{~mA} / 1 \mathrm{~s}$ e sessão de extinção de $20 \mathrm{~min}$.................................. 48 3.14.2. Protocolo experimental 2: Participação dos receptores glicocorticoides, presentes na porção IL ou PL do CPFvm no processo de consolidação da extinção de memória aversiva, em animais estressados e não estressados ......................... 49 3.14.3. Protocolo experimental 3: Participação dos receptores mineralocorticoides, presentes na porção IL ou PL do CPFvm no processo de consolidação da extinção de memória aversiva, em animais estressados e não estressados .......................... 49 3.14.4. Protocolo experimental 4: Investigação do perfil de extinção da memória aversiva quando da realização da sessão de extinção durante o pico do ciclo circadiano de corticosterona dos animais ..........................................................5 50

3.14.5. Protocolo experimental 5: Ensaio experimental para a coleta de amostras de sangue para aferição dos níveis plasmáticos de corticosterona ..............................50 3.14.6. Protocolo experimental 6: Ensaio experimental para coleta do encéfalo dos animais para a análise de GolgiStain, ou retirada específica de amostras do córtex pré-frontal ventromedial para análise de WB ......................................................5 50

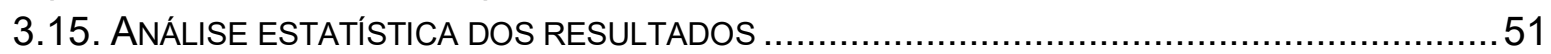

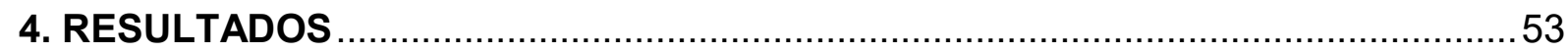

4.1. O PAPEL DO ESTRESSE AGUdO NO PROCESSO DE EXTINÇÃO DA MEMÓRIA DE

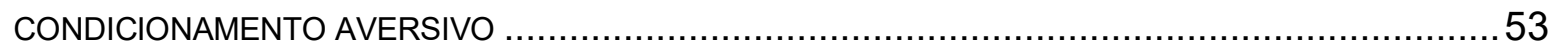

4.2. PARTICIPAÇÃO DOS RECEPTORES PARA GLICOCORTICOIDES, PRESENTES NA PORÇÃO IL DO CPFVM, SOBRE A CONSOLIDAÇÃO DA EXTINÇÃO DE MEMÓRIA AVERSIVA EM ANIMAIS ESTRESSADOS E NÃO ESTRESSADOS 
4.3. PARTICIPAÇÃO DOS RECEPTORES PARA GLICOCORTICOIDES, PRESENTES NA PORÇÃO PL DO CPFVM, SOBRE A CONSOLIDAÇÃO DA EXTINÇÃO DE MEMÓRIA AVERSIVA EM ANIMAIS ESTRESSADOS E NÃO ESTRESSADOS

4.4. PARTICIPAÇÃO DOS RECEPTORES PARA MINERALOCORTICOIDES, PRESENTES NA PORÇÃO IL DO CPFVM, SOBRE A CONSOLIDAÇÃO DA EXTINÇÃO DE MEMÓRIA AVERSIVA EM ANIMAIS ESTRESSADOS E NÃO ESTRESSADOS.

4.5. INVESTIGAÇÃO DO PERFIL DE EXTINÇÃO DA MEMÓRIA AVERSIVA QUANDO DA REALIZAÇÃO DA SESSÃO DE EXTINÇÃO DURANTE O PICO DO CICLO CIRCADIANO DE CORTICOSTERONA DOS ANIMAIS

4.6. ANÁLISE DOS NÍVEIS PLASMÁTICOS DE CORTICOSTERONA APÓS O ESTRESSE POR RESTRIÇÃO E APÓS AS SESSÕES DE CONDICIONAMENTO, EXTINÇÃO E TESTE DA RETENÇÃO DA MEMÓRIA DE EXTINÇÃO.

4.7. ANÁLISE DA DENSIDADE DE ESPINHOS DENDRÍTICOS NO CPFVM, APÓS O TÉRMINO DA SESSÃO DE EXTINÇÃO NA TAREFA DE MCC.

4.8. ANÁLISE DA EXPRESSÃO DOS RECEPTORES MINERALOCORTICOIDE E GLICOCORTICOIDE NO CPFVM, APÓS O TÉRMINO DA SESSÃO DE EXTINÇÃO NA TAREFA DE MCC 63

5. DISCUSSÃO 66

6. CONCLUSÃO .74

7. CONSIDERAÇÕES FINAIS 76

REFERÊNCIAS BIBLIOGRÁFICAS 83

APÊNDICE A - ESTUDO PILOTO. 102

ANEXO I - CARTA DE APROVAÇÃO PELO CONSELHO NACIONAL DE CONTROLE DE EXPERIMENTAÇÃO ANIMAL (CONSEA) DO PROJETO QUE DEU ORIGEM A ESTA TESE (N069/2015).

ANEXO II - FICHA DO ALUNO - SISTEMA JANUS (SISTEMA ADMINISTRATIVO DA PÓS-GRADUAÇÃO) DA USP

ANEXO III - NÚMERO DO PROCESSO DE BOLSA DE DOUTORADO NO PAÍS, CONCEDIDA PELA FAPESP

ANEXO IV - NÚMERO DO PROCESSO DE BOLSA DE ESTÁGIO DE PESQUISA NO EXTERIOR (BEPE), CONCEDIDA PELA FAPESP 119

ANEXO VI - FORMULÁRIO DE SOLICITAÇÃO DE ALUNO PARA PRORROGAÇÃO DO PRAZO PARA A DEFESA

ANEXO VII - PARECER AS SECRETÁRIA DE PÓS-GRADUAÇÃO DA FMRP-USP.. 130

ANEXO VIII - CANCELAMENTO DA BOLSA FAPESP (BOLSA NO PAÍS) 132

ANEXO IX - CARTA DE ACEITE DO SUPERVISOR NO EXTERIOR DURANTE O PERÍODO DA BEPE FAPESP.

ANEXO $\mathbf{X}$ - PROJETO BEPE FAPESP. 136

ANEXO XI - ATA DE DEFESA 


\section{INTRODUÇÃO}

"I've learned that people will forget what you said, people will forget what you did, but people will never forget how you made them feel."

Carl W. Buehner

As emoções exercem forte influência sobre os processos de memória. É possível afirmar que as memórias adquiridas sob a presença de intensos componentes emocionais dificilmente serão esquecidas. Geralmente são as que mais persistem (Mueller and Cahill 2010; Izquierdo et al. 2016; LaLumiere et al. 2017). A memória, sob a luz da ciência, é a faculdade que permite a humanidade lembrar de seu passado e projetar o seu futuro (Araujo et al., 2014; Izquierdo, 2015; McGaugh, 2015). Nosso conhecimento sobre a nossa história, sobre a matemática ou a geografia e tantos outros saberes acerca de nosso mundo externo, chamamos de memórias semânticas (Burianova, McIntosh e Grady, 2010; Dickerson e Eichenbaum, 2009; Izquierdo, 2002; Kompus et al., 2009; Renoult et al., 2012). Por outro lado, as memórias para eventos autobiográficos, aqueles em que estamos diretamente envolvidos, presentes, como a recordação da comemoração de um evento familiar, chamamos de memórias episódicas (Burianova, Mclntosh e Grady, 2010; Conway, 2009; Izquierdo, 2002; Kompus et al., 2009; Renoult et al., 2012). Ambas, semânticas e episódicas, são memórias consideradas declarativas. Em outras palavras, podemos relatar como aprendemos e detalhes da experiência. $E$ há memórias que nos permite a execução de tarefas ou reações comportamentais, e são chamadas de não declarativas. Trata-se de memórias que não precisam ser verbalizadas, e nos permite a recordação de procedimentos para executarmos habilidades motoras, como dirigir ou andar de bicicleta (Bear, 2002; Izquierdo, 2002; Schuchard e Thompson, 2013). Todos estes tipos de memórias passam por alguns processos para a sua formação. Processos estes que envolvem a participação de neurotransmissores e receptores em diversas regiões do cérebro, resultando em modificações a nível de sinalizações bioquímicas e formação de novas conexões sinápticas (Akirav e Maroun, 2012; Alberini e LeDoux, 2013; De la Cruz et al., 2008; McGaugh, J L e Izquierdo, 2000).

O aprendizado, ou fase de aquisição de uma nova informação ou experiência, é o primeiro processo para a formação de uma memória (Johansen et al., 2011; Squire, 2009; Szapiro et al., 2002). Mas só é possível saber se um aprendizado gerou 
a formação de uma memória, se posteriormente é possível recordar, ou evocar, tal aprendizado (Garelick e Storm, 2005; Izquierdo, I. et al., 2002; Lopez et al., 2015; Szapiro et al., 2002). E a evocação de um aprendizado só é possível quando ocorre um processo chamado consolidação (LaLumiere, McGaugh e Mclntyre, 2017; McGaugh, 2015). Este processo em que ocorrem a síntese de novas proteínas e alterações plásticas nos neurônios, permite o armazenamento de uma informação no cérebro (Schafe e LeDoux, 2000; Vianna et al., 2001). Os processos de aquisição, consolidação e evocação ocorrem em memórias de longa duração. Esta se refere a informações e aprendizados que persistem por vários dias, ou muitos anos, neste último caso também chamadas de memórias remotas (Giese e Mizuno, 2013; LaLumiere, McGaugh e McIntyre, 2017; Lamprecht e LeDoux, 2004). Já para a formação de memórias de curta duração, não ocorre alterações plásticas permanentes como na memória de longa de duração: as alterações sinápticas são transitórias, de modo que permitem o armazenamento de pouco conteúdo por algumas horas (Baddeley, 2012; Izquierdo et al., 1999). Importante salientar que as memórias de curta duração diferem da memória de trabalho, que é efêmera, e ocorrem basicamente pela atividade neuronial do córtex pré-frontal (CPF). Esta possui unicamente papel gerenciador, permitindo por exemplo, que saibamos distinguir uma experiência ou informação como sendo uma novidade ou não (Baddeley 1992, 2012; D’Esposito et al. 1995; Zanto et al. 2011).

Estes processos de memória são estudados mediante ensaios clínicos, bem como em ensaios experimentais em laboratório, por meio da aplicação de alguns paradigmas comportamentais em roedores. O medo condicionado ao contexto (MCC) é um ensaio experimental amplamente utilizado em estudos acerca dos processos de memória (Domingos et al., 2017; Fiorenza et al., 2012; Fitzgerald, Seemann e Maren, 2013; Schiller et al., 2013), pois, nos proporciona uma interface entre memória e emoção (Bentz et al., 2013; LeDoux, 2000). Trata-se do condicionamento clássico, considerado um tipo de memória não declarativa ou implícita em relação ao seu conteúdo: $O$ animal aprende que com estímulos ambientais pode prever um estímulo aversivo, ou seja, aprende a associar o ambiente em que é exposto (estímulo neutro/condicionado) ao estímulo elétrico (estímulo aversivo/incondicionado). Uma vez exposto ao contexto em que foi realizado o pareamento, o animal não tem a possibilidade de fuga, e então emite uma resposta emocional condicionada (REC), que envolve o parâmetro comportamental inato denominado Freezing (imobilidade 
total do animal, exceto os movimentos respiratórios) (Bolles e Collier, 1976; Garelick e Storm, 2005; Izquierdo, Furini e Myskiw, 2016; VanElzakker et al., 2014), bem como alterações autonômicas, tais como o aumento da pressão arterial média (PAM) e frequência cardíaca (FC), e diminuição da temperatura cutânea (TC) (Resstel et al., 2006; Uliana et al., 2016). A posterior exposição, muito brevemente do animal ao contexto na ausência do estímulo aversivo/incondicionado, produz um fortalecimento do traço mnemônico, ou até mesmo o acréscimo de uma nova informação a memória aversiva de longa duração inicialmente formada, o que chamamos de reconsolidação (Bermúdez-Rattoni e McGaugh, 2017; Lee, Nader e Schiller, 2017; Nader, 2015). Mas a exposição prolongada ao contexto na ausência do estímulo aversivo/incondicionado produz um gradual decréscimo na REC decorrente da memória aversiva previamente consolidada, onde se observa o aprendizado de uma nova memória: a memória de extinção (Furini et al., 2013; Mueller e Cahill, 2010; Orsini e Maren, 2012; Rescorla, Robert A, 2004; Singewald, Schmuckermair, Whittle, Holmes e Ressler, K. J., 2014; VanElzakker et al., 2014). E este processo este é conhecido como sessão de extinção (Kaplan e Moore, 2011; Mueller e Cahill, 2010; Quirk, Garcia e González-Lima, 2006). Este ensaio comportamental permite o estudo dos processos de memória aversiva em sua totalidade, ou seja, pode-se obter informações acerca da capacidade de lembrança (evocação) da experiência aversiva previamente adquirida (aprendida) e armazenada (consolidada), bem como a sua reconsolidação (Rodriguez-Ortiz et al., 2012; Sachser et al., 2015; Schwabe, Nader e Pruessner, 2014) ou a sua extinção (Fiorenza et al., 2012; Lisboa et al., 2015; Santini, 2004). Ainda é possível aferir, após a fase de aprendizado/consolidação desta tarefa, informações sobre a memória de curta duração, e a memória de longa duração do aprendizado do medo condicionado. Para isso, uma janela de tempo é aplicada. Usualmente uma reexposição a caixa de condicionamento na ausência de estímulo entre $30 \mathrm{~min}$ e $3 \mathrm{~h}$ pode-se obter informações sobre a memória aversiva de curta duração (Chen et al., 2010; Izquierdo et al., 1998), e após 24h sobre a memória de longa duração. (Fiorenza et al., 2012; Sachser et al., 2015). Também é possível, utilizando o MCC, realizar a administração central ou periférica de drogas nos animais, durante as diferentes etapas dos processos de memória, para se conhecer sistemas e receptores envolvidos na aquisição e armazenamento e expressão da memória de condicionamento em seus diferentes tempos e seus processos de formação (Barros et al., 2002; Fitzgerald, Seemann e Maren, 2013; McGaugh, 2015; McGaugh, J. L. e Izquierdo, 2000; Myskiw, 
Izquierdo e Furini, 2014; Roesler e Schröder, 2011; Rosa et al., 2014). Particularmente no caso do estudo farmacológico do aprendizado da extinção de uma memória aversiva, podemos aferir a participação de determinados receptores, ou efeito de possíveis fármacos sobre este processo mnemônico, mediante a administração de drogas ou fármacos em momentos distintos: antes da sessão extinção, obtendo informações acerca da aquisição e/ou consolidação da extinção (dependendo do tempo de meia vida da droga ou fármaco); ou após a sessão de extinção, obtendo informações acerca do processo de consolidação da memória de extinção. $E$ tais efeitos são testados $24 \mathrm{~h}$ após ou mais, para verificação da retenção da memória extinção (Domingos et al., 2017; Fiorenza et al., 2012). Compreender como estes processos de memória funcionam, submetendo-os a óptica da farmacologia, fisiologia, neurociência e biologia molecular, impactam em muitos aspectos da vida humana. Isto inclui a saúde mental, considerando que muitas memórias aversivas podem desencadear transtornos afetivos (LaLumiere, McGaugh e Mclntyre, 2017; Maren e Holmes, 2016; Parsons e Ressler, 2013).

Como citado anteriormente, as memórias são influenciadas pelos estados emocionais, especialmente pelo medo (McGaugh, 2015; Mueller e Cahill, 2010). O medo é um sentimento, um estado emocional que surge de respostas comportamentais e fisiológicas frente a situações aversivas (Izquierdo, Furini e Myskiw, 2016; Johansen et al., 2011). Por exemplo, pode desencadear o processo de generalização de uma memória aversiva, processo em que o medo sentido em uma determinada situação, seja transferido para outras situações que possuam semelhanças com a situação atemorizante vivida anteriormente (Asok, Kandel e Rayman, 2018; Lopresto, Schipper e Homberg, 2016). A extinção, portanto, principalmente em casos de exposição a uma memória de medo extremo ou traumática, possui uma enorme importância fisiológica e/ou adaptativa, visto que evocar excessivos detalhes de memórias com conteúdo doloroso ou aterrorizante, em momentos inapropriados e de forma recorrente, pode ocasionar estragos em nossa saúde emocional (Izquierdo, Furini e Myskiw, 2016; Morrison e Ressler, 2014; Quirk, 2017), propiciando o desenvolvimento de transtornos psiquiátricos, como o transtorno de estresse pós-traumático (do inglês post-traumatic stress disorder; PTSD) (Brewin e Holmes, 2003; Furini et al., 2013; Morrison e Ressler, 2014; VanElzakker et al., 2014). 
O PTSD uma doença crônica, debilitante que surge de uma resposta anormal do indivíduo mediante a exposição a um evento traumático, afetando $3,5 \%$ da população adulta nos Estados Unidos, segundo a Sociedade Americana de Psiquiatria (American Psychiatric Association, [s.d.]). Os pacientes acometidos por este transtorno passam a sofrer com a ocorrência de memórias intrusas, persistentes e muito vívidas ("flashbacks"), se esquivam de pessoas, ambientes e situações que favorecem o surgimento das memórias angustiantes, possuem crenças persistentes e distorcidas sobre si mesmo e mostram persistente hiperexitação autonômica (American Psychiatric Association, [s.d.]; Maren, Phan e Liberzon, 2013; Quevedo et al., 2003; Singewald, Schmuckermair, Whittle, Holmes e Ressler, K. J., 2014; VanElzakker et al., 2014). Uma maneira de tratar este transtorno psiquiátrico e devolver aos pacientes a estabilidade emocional, tão necessária à qualidade de vida, adaptação e sobrevivência humana, é através da terapia de exposição (Fitzgerald, Seemann e Maren, 2013), técnica muito utilizada na clínica e baseada na extinção (Abramowitz, 2013; American Psychiatric Association, [s.d.]; Bremner, 2006; Brewin e Holmes, 2003; Carvalho Myskiw, de, Benetti e Izquierdo, 2012; Fiorenza et al., 2012; Miyashita e Williams, 2004; Rauch et al., 2009; Thorp et al., 2012). Ambas consistem em expor o sujeito ao estímulo aversivo, sem as suas consequências perigosas ou assustadoras, resultando em um gradual decréscimo do comportamento de medo (Kaplan e Moore, 2011; Orsini e Maren, 2012). Não se trata do esquecimento da memória de medo, mas de um novo aprendizado que a inibe a evocação de uma memória previamente consolidada (Izquierdo et al. 2002, 2016). Isto porque a memória de extinção pode sofrer recuperação espontânea, onde passa a ser evocada novamente em sua totalidade com o passar do tempo (Kindt, 2018; Rescorla, R. A., 2004; Singewald, Schmuckermair, Whittle, Holmes e Ressler, K.J., 2014; Stockhorst e Antov, 2016). Conduto, existem vários efeitos secundários desta terapia, sendo o mais notável, a angústia às vezes causada pela evocação do episódio traumático no processo. Os custos decorrentes do tratamento são altos e as terapias farmacológicas aprovadas pelo FDA (Food and drug administration - órgão americano que regulamenta os medicamentos nos Estados Unidos) são escassas e em alguns casos ineficientes (George et al., 2015; Singewald, Schmuckermair, Whittle, Holmes e Ressler, K. J., 2014). Além disso, estudos apontam que estes pacientes apresentam déficit no aprendizado da extinção das respostas de medo adquiridas (Asukai, 2013; Gourley et al., 2009; Kolber, Wieczorek e Muglia, 2008). 
Por tratar-se de um novo aprendizado, a memória de extinção necessita ser adquirida e consolidada (Izquierdo, I. et al., 2002; Stockhorst e Antov, 2016; Vianna et al., 2001), e requer a participação de diversas estruturas encefálicas para o seu processamento, incluindo o córtex pré-frontal (CPF) (Berlau e Mcgaugh, 2006; Fiorenza et al., 2012; Kaplan e Moore, 2011; Orsini e Maren, 2012). O CPF é uma estrutura límbica que desempenha funções executivas e de regulação das emoções e do comportamento (Lu e Richardson, 2014; McKlveen et al., 2013; Popoli et al., 2012). E possui um papel importante na modulação das respostas autonômicas (Fassini et al., 2015; Ferreira-Junior et al., 2013; Lisboa, S.F. et al., 2010; Resstel e Corrêa, 2006). Em humanos e roedores, a porção ventromedial do CPF (CPFvm) tem sido considerada como um importante sítio para o controle da extinção do medo condicionado (Fiorenza et al., 2012; Lonsdorf, Haaker e Kalisch, 2014; Popoli et al., 2012; Raio et al., 2014). Em roedores esta estrutura é subdivida em duas regiões: prélimbica $(P L)$, que é essencial para o armazenamento e expressão do medo condicionado (Fukushima et al., 2014); e a região infralímbica (IL) que desempenha um papel importante na aquisição e consolidação da extinção e sua evocação (Knox et al., 2012; Maren, Phan e Liberzon, 2013). É observado um déficit na evocação da memória de extinção e uma diminuição na densidade de espinhos dendríticos no CPFvm, quando em decorrência da exposição de indivíduos ao estresse crônico, ou da ativação patológica desta estrutura encefálica (McKlveen et al., 2013; Moench e Wellman, 2014), evidenciando o papel desta estrutura encefálica na modulação das respostas de estresse. Porém, quanto aos efeitos do estresse agudo sobre a performance da extinção e da densidade de espinhos dendríticos no CPFvm, mais estudos se fazem necessário. O CPF faz conexões com outras estruturas encefálicas. Projeções do PL parecem estabelecer conexão com o Núcleo basal e central da amígdala, enquanto o IL mantém conexões com grande parte do complexo amigdaloide. Contudo, PL e IL recebem projeções da amígdala basolateral (Hübner et al., 2014; Milad e Quirk, 2012; Singewald, Schmuckermair, Whittle, Holmes e Ressler, K. J., 2014), e ambas as regiões processam memórias para eventos negativos e controlam a magnitude das respostas fisiológicas as adversidades, incluindo a liberação de hormônios do estresse, como os glicocorticoides (McKlveen et al., 2013; Moench e Wellman, 2014).

Experiências estressantes fazem parte de nosso cotidiano e possuem um papel crítico em nossa capacidade de adaptação às adversidades, em nossa competência 
em distinguir situação seguras de situações perigosas (Izquierdo, Furini e Myskiw, 2016; Morrison e Ressler, 2014; Quirk, 2017). O estresse, que pode ser definido como uma ameaça real ou imaginaria a homeostase, tem efeito dual sobre a cognição: pode promover a melhora da capacidade cognitiva, tendo consequências pró-adaptativas; ou ter efeitos deletérios sobre esta, resultando em respostas mal-adaptativas (Quervain, de, Wolf e Roozendaal, 2019; Quervain, de, Schwabe e Roozendaal, 2017; Cordero et al., 2003; Treccani et al., 2014; Tsigos e Chrousos, 2002; Oitzl et al., 2010; Sapolsky, 2015; Szabo, Tache e Somogyi, 2012; Selye, 1976). Este efeito dual do estresse sobre a cognição e comportamento depende de fatores intrínsecos e extrínsecos ao indivíduo. Características como genética, estilo de vida, ambiente social, são determinantes para causar a susceptibilidade aos efeitos deletérios do estresse. Há também duas características importantes: a intensidade e frequência do estímulo estressor (Crestani, 2016; Sandi, 2013; Selye, 1976; Wu e Yan, 2017). Em conjunto, estes fatores geram resultados bastantes controversos na literatura científica (Bentz et al., 2013; Bremner, 2006; Clay et al., 2011; Kaouane et al., 2012; Kinner et al., 2016; Merz et al., 2014; Raio et al., 2014; Solomon et al., 2014; Wolf et al., 2016). Em estudos em que o estresse foi empregado cronicamente, observa-se um prejuízo das funções executivas, (memória de trabalho), da memória de curta duração e atenção, ao mesmo tempo que parece haver uma facilitação do processo de consolidação da memória de medo condicionado contextual (Brand, Hanson e Godaert, 2000; Cordero et al., 2003; Izquierdo, L. A. et al., 2002; Mika et al., 2012; Quervain, de, Wolf e Roozendaal, 2019; Wolf et al., 2016). Enquanto que a exposição aguda ao estresse pode ocasionar a retração dendrítica nos terminais apicais de neurônios piramidais da porção IL do CPFvm e prejuízo na extinção de memória aversiva (Izquierdo, Wellman e Holmes, 2006). Outro estudo aponta que o estresse agudo é capaz de provocar mudanças na morfologia de neurônios piramidais das camadas II e III da porção PL do CPFvm, e que tal efeito pode ser sustentado por até 14 dias, influenciando a liberação de neurotransmissores (Musazzi et al., 2017; Nava et al., 2015). Estas evidências nos colocam diante da questão de que o estresse agudo pode ter efeitos crônicos, e estes efeitos precisam ser melhor investigados.

Dentre os sistemas que estão envolvidos nas respostas de estresse em mamíferos, um dos mais importantes e intensamente estudado é o sistema endócrino, compreendendo o eixo hipotálamo-hipófise-adrenal (HPA) (Atsak et al., 2012; Cahill e McGaugh, 1996; Ghosal et al., 2014; Kaouane et al., 2012; Knox et al., 2012; McEown 
e Treit, 2011; Oliveira, de, Reimer e Brandão, 2014; Quervain, de, Wolf e Roozendaal, 2019; Raio et al., 2014; Roozendaal e McGaugh, 1997). O estresse fisiológico, ou psicológico, ativa o eixo hipotálamo-hipófise-adrenal (HPA), onde o hipotálamo secreta o hormônio liberador de corticotrofina (HLC) na circulação hipotálamohipofisária, estimulando a liberação do hormônio adrenocorticotrópico (adrenocorticotropic Hormone - ACTH) pela hipófise anterior (ou adeno-hipófise) para a circulação geral, e este por sua vez, estimula a liberação sistêmica de glicocorticoides pelo córtex da glândula supra-renal (Bear, 2002; Kolber, Wieczorek e Muglia, 2008; Myers, McKlveen e Herman, 2014). O cortisol, hormônio glicocorticoide em humanos, e a corticosterona, hormônio glicocorticoide em roedores (Myers, McKlveen e Herman, 2014), após liberados na circulação sistêmica, atravessam a barreira hematoencefálica, e exercem seus efeitos biológicos ao se ligarem aos receptores do tipo mineralocorticoide, em condições basais, e receptores glicocorticoide, durante o pico do ciclo circadiano deste hormônio, ou em condições de estresse (Kolber, Wieczorek e Muglia, 2008; Myers, McKlveen e Herman, 2014; Roesler e Schröder, 2011; Sapolsky, 2015; Solomon et al., 2014). Os receptores para glicocorticoides são cruciais para a manutenção da homeostasia após condições de estresse psicológico ou fisiológico. Os hormônios glicocorticoides exercem seus efeitos por meio de dois mecanismos distintos: mecanismos genômicos e nãogenômicos. O mecanismo clássico é por ação genômica. Ligam-se a receptores intracelulares que, após dimerização, migram para o núcleo interagindo com o DNA por mecanismos de transativação ou transrepressão. Ou seja, ativando ou suprimindo a síntese de determinadas proteínas, respectivamente. O mecanismo de ação nãogenômico é o meio pelo qual se observam os efeitos rápidos da ação dos hormônios glicocorticoides. Ocorre pela interação com receptores citosólicos. A sinalização e expressão apropriadas destes receptores em diferentes regiões encefálicas é crítica para a regulação do eixo HPA, controle das respostas emocionais e performance cognitiva (Kloet, de et al., 2018; Kolber, Wieczorek e Muglia, 2008; Makara e Haller, 2001; Oitzl et al., 2010; Stahn e Buttgereit, 2008; Treccani et al., 2014; Wolf et al., 2016). E tem sido proposto que alterações na expressão e atividade dos receptores mineralocorticoide e glicocorticoide pode contribuir para o desenvolvimento de doenças psiquiátricas (Haarst, van, Oitzl e Kloet, de, 1997; Han, Ding e Shi, 2014; Kloet, de, 2000, 2014; Klok et al., 2011; Kolber, Wieczorek e Muglia, 2008; Qi et al., 2013; Xing et al., 2004). Alguns autores têm considerado o papel dual dos hormônios 
glicocorticoides sobre a cognição, e seus possíveis efeitos positivos, com o intuito de desenvolver estudos que possam maximizar a efetividade da terapia de exposição. Deste modo, estudos clínicos e experimentais têm sugerido que o cortisol pode ser um agente capaz de melhorar o processo de extinção de memória, facilitando este processo mnemônico. Alguns autores sugerem a administração de glicocorticoides como uma ferramenta farmacológica para reduzir o sentimento de medo e fobias em pacientes, bem como facilitar as respostas positivas da terapia de exposição (Kinner et al., 2016; Merz et al., 2014; Quervain, de, Schwabe e Roozendaal, 2017; Quervain, de, Wolf e Roozendaal, 2019; Quervain, de e Margraf, 2008; Wolf et al., 2016). Da mesma forma os níveis de cortisol endógeno parecem influenciar o processo de extinção (Meuret et al., 2015, 2016). Lass-Hannemann e Michael demonstraram que a terapia de exposição é mais efetiva quando realizada no período matutino, durante o pico do ciclo circadiano do cortisol em humanos (Lass-Hennemann e Michael, 2014). Estes achados parecem promissores, porém seus mecanismos permanecem obscuros.

Em razão de sua relevância clínica, os mecanismos que envolvem o processo extinção tem sido foco de intensos estudos (Berlau e Mcgaugh, 2006; Carvalho Myskiw, de, Benetti e Izquierdo, 2012; Fiorenza et al., 2012; Fitzgerald, Seemann e Maren, 2013; Ganon-Elazar e Akirav, 2013; Maren, Phan e Liberzon, 2013). E tem sido proposto que a exposição ao estresse pode ser um fator de predisposição para o desenvolvimento do PTSD em indivíduos susceptíveis após serem submetidos a um evento traumático, e a extinção da memória aversiva parece estar prejudicada neste transtorno psiquiátrico (Asukai, 2013; Cordero et al., 2003; Gourley et al., 2009; Kolber, Wieczorek e Muglia, 2008; Musazzi et al., 2017; Wicking et al., 2016). Um modelo experimental bastante empregado para se compreender os efeitos do estresse é o estresse por restrição (ER). Trata-se de um ensaio que quando aplicado de maneira aguda em roedores, gera um estado de estresse de maneira incontrolável e imprevisível. O experimento consiste em submeter roedores a um tubo cilíndrico ou semi-cilíndrico ventilados, onde permanecem com seus movimentos contidos por um período de tempo a depender do protocolo empregado e da pretensão da intensidade do estresse gerado. Após este estresse físico e psicológico, podem ser mensuradas experimentalmente, as alterações fisiológicas como as de ordem autonômicas, comportamentais e aumento dos níveis de hormônios glicocorticoides (Borghans, 2015; Campos et al., 2013; Crestani, 2016; Resstel et al., 2009). Contudo, as 
consequências do estresse agudo e seus possíveis efeitos sustentados, ou do papel desempenhado pelos receptores de glicocorticoides e mineralocorticoides para o aprendizado da extinção, ainda são pouco conhecidos.

Estudos clínicos apontam que pacientes com diagnóstico de PTSD podem apresentar alteração do ciclo circadiano de glicocorticoides e alterações neurofuncionais do CPFvm (Daskalakis, Lehrner e Yehuda, 2013; Maren, Phan e Liberzon, 2013; Moench e Wellman, 2014; Rougemont-Bücking et al., 2011; Singewald, Schmuckermair, Whittle, Holmes e Ressler, K. J., 2014). A porção ventromedial do córtex pré-frontal, compreendendo as regiões PL e IL [a região IL é comparável ao CPFvm em humanos; (Milad e Quirk, 2012; Singewald, Schmuckermair, Whittle, Holmes e Ressler, K. J., 2014)] tem sido considerado como um importante sítio envolvido nas respostas cardiovasculares, neuroendócrinas e comportamentais (Cahill e McGaugh, 1996; Ferreira-Junior et al., 2013; Lemos, Resstel e Guimarães, 2010; Mueller, Porter e Quirk, 2008; Pizzorusso, 2009; Resstel e Corrêa, 2006; Santini, 2004), e onde há uma rica expressão de receptores glicocorticoides. Isto sugere que a regulação das respostas ao estresse pelo CPFvm pode ser mediada pelo feedback deste hormônio (McKlveen et al., 2013; Mizoguchi et al., 2009). Deste modo, a hipótese desta presente Tese é que os receptores mineralocorticoide e glicocorticoide presentes no CPFvm participem do processo de extinção da memória aversiva, e que o estresse agudo seja capaz, por meio de seus efeitos sustentados, produzir um déficit no processo de extinção do medo condicionado contextual por meio de alterações na expressão dos receptores para glicocorticoides no CPFvm, bem como remodelamento dendrítico em neurônios piramidais das camadas II e III desta estrutura encefálica. 


\section{OBJETIVOS}

\subsection{Objetivo Geral}

Investigar a participação dos receptores glicocorticoides e mineralocorticoides presentes no CPFvm, no processo de extinção de memória aversiva em animais submetidos ao estresse agudo imprevisível e inescapável.

\subsection{Objetivos específicos}

- Verificar o perfil de extinção de memória aversiva em animais previamente submetidos ao estresse agudo imprevisível e inescapável.

- Verificar a participação dos receptores mineralocorticoide e/ou glicocorticoide, presentes nas porções PL e/ou IL do CPFvm, no processo de consolidação da extinção de memória aversiva em animais submetidos previamente ao estresse agudo imprevisível e inescapável.

- Verificar o perfil de extinção de memória aversiva, durante as diferentes fases do ciclo circadiano de corticosterona, em animais submetidos ao estresse agudo imprevisível e inescapável.

- Verificar o registro da resposta emocional condicionada (REC) dos animais, durante as sessões de condicionamento, extinção e teste da retenção da memória de extinção no paradigma de $\mathrm{MCC}$, em animais previamente submetidos ao estresse agudo imprevisível e inescapável.

- Verificar a concentração plasmática de corticosterona durante a performance de treino, extinção e durante o teste da retenção da memória de extinção na tarefa comportamental de MCC em animais submetidos ao estresse agudo imprevisível e inescapável.

- Verificar a densidade de espinhos dendríticos de neurônios piramidais das camadas II e III das porções PL e IL do CPFvm, em animais submetidos a um estresse agudo imprevisível e inescapável prévio ao MCC.

- Verificar a expressão dos receptores glicocorticoide e mineralocorticoide presentes no CPFvm, em animais submetidos a um estresse agudo imprevisível e inescapável prévio ao MCC. 


\section{MATERIAS E MÉTODOS}

\subsection{Animais}

Foram utilizados ratos (Rattus norvegicus) da linhagem Wistar machos (de 4555 dias de idade; pesando entre 290-360g), fornecidos pelo biotério central da Universidade de São Paulo (USP), Ribeirão Preto. Durante toda a fase experimental os animais foram mantidos na sala de alojamento do laboratório de Neurofarmacologia, da Faculdade de Medicina, Departamento de Farmacologia da USP. Estes foram acomodados em caixas plásticas especiais forradas com maravalha, com capacidade para 4 animais, e após os procedimentos cirúrgicos de canulação da aorta abdominal ou inserção da sonda radio-telemétrica, transferidos para caixas individuais para recuperação. Permaneceram durante todo o tempo em condições controladas de luz (ciclo 12 horas claro/escuro - luz a partir das 6:30 horas) e temperatura $\left(23-25^{\circ} \mathrm{C}\right)$, recebendo água e ração ad libitum. As caixas de alojamento foram trocadas e limpas a cada dois dias, e as tarefas comportamentais realizadas durante a fase clara do ciclo dos animais, no período matutino, evitando o período vespertino onde há elevação dos níveis de glicocorticoides em roedores (pico circadiano) (Kolber et al 2008), exceto quando em cumprimento do terceiro objetivo específico apresentado nesta Tese, que previa verificar o perfil de extinção de memória aversiva, nos dois ensaios comportamentais propostos, durante as diferentes fases do ciclo circadiano de corticosterona. Os procedimentos experimentais foram conduzidos de acordo com as diretrizes da Sociedade Brasileira de Neurociências e Comportamento sobre os cuidados com animais de laboratório, que estão de acordo com as normas do Conselho Nacional de Controle de Experimentação Animal (CONCEA) dispostas na lei Arouca (11.794/08). Este projeto foi submetido à análise junto a Comissão de Ética no Uso de Animais da Faculdade de Medicina desta Instituição, obtendo parecer favorável (69/2015 CEUA-FMRP).

\subsection{Cirurgia estereotáxica}

Após a aclimatação dos animais ao nosso biotério, foi realizada a cirurgia estereotáxica, com o propósito de viabilizar a administração das drogas, ou de seus 
veículos nas regiões encefálicas alvos de estudo. Para tal fim, os animais foram previamente anestesiados por meio de administração intraperitoneal (i.p.) de ketamina (Dopalen; Sespo Industria e Comércio Ltda, Brasil) 75 mg/Kg e xilazina (Dopaser; Laboratório Calier S.A, Espanha) $10 \mathrm{mg} / \mathrm{Kg}$ (Benetti et al., 2014), e, por meio de um aparelho estereotáxico foi conduzida a implantação bilateral de cânulas-guia, de 26 gouge $(G)$, na calota craniana dos animais, de modo que permaneceram fixadas a 1 $\mathrm{mm}$ acima da regiões PL ou IL do CPFvm. As coordenadas utilizadas foram: CPFvm PL: Antero-posterior (AP) +3,4, Latero-lateral (LL) +2,5, Dorso-ventral (DV) -3,3 mm, com incisivo em -3,2 e inclinação de ambas as torres em 24우 CPFvm IL: AP +3,4, LL $+2,5$, DV -3,2 mm, com incisivo em -3,2 e inclinação de ambas as torres em $24^{\circ}$. A execução desta técnica cirurgia foi conforme descrita por Granjeiro e colaboradores (Granjeiro et al., 2011).

\subsection{Sessão única de estresse por restrição}

Após 4 dias de recuperação da cirurgia estereotáxica, um grupo de animais foi submetido, individualmente, à uma única sessão de estresse por restrição, em que permaneceram com seus movimentos restritos em tubos de aço inox, semi-cilíndricos com $6,5 \mathrm{~cm}$ de largura e $20,5 \mathrm{~cm}$ de comprimento, de forma ininterrupta durante um período de $1 \mathrm{~h}$. O outro grupo de animais permaneceu no biotério em condições habituais. Adaptado de Rodrigues e colaboradores (Rodrigues et al., 2015).

\subsection{Cirurgia para canulação da aorta abdominal}

Após $24 \mathrm{~h}$ da sessão de estresse por restrição, com a finalidade de coletar amostras de sangue em diferentes momentos do protocolo experimental, para aferir os níveis plasmáticos de corticosterona, um cateter de polietileno flexível (PE-10: .011" x .024" x 10', conectado a um PE-50: .023 x .038 x 100'; Intramedic, Clay Adams Brand, New Jersey, USA), previamente preenchido com solução salina 0,9\% e obstruído com um pino de metal, foi implantado na aorta descendente (Faria-Silva, Duarte e Santos, 2005; Santos et al., 2015) de um grupo de animais. Este procedimento foi realizado após completa indução de anestesia nos animais por meio da administração i.p. de ketamina e xilazina 75 e $10 \mathrm{mg} / \mathrm{Kg}$, respectivamente. $O$ animal 
anestesiado foi colocado em uma prancha operatória, onde após a tricotomia e assepsia de seu abdômen, foi realizada uma incisão de cerca de $3 \mathrm{~cm}$, expondo a aorta descendente. Isolando-se adequadamente a aorta e erguendo-a com auxílio de uma linha de algodão para interromper rapidamente seu fluxo, foi realizada uma pequena incisão na artéria com auxílio da ponta de uma agulha de 27,5 G (BD Bioscences), por onde o cateter flexível de polietileno foi cuidadosamente inserido no lúmen do vaso (Oliveira et al., 2015). O local da incisão foi então selado com um adesivo tecidual. Normalizado o fluxo sanguíneo, e com a cânula de polietileno gentilmente acomodado na cavidade abdominal, foi realizada a sutura da incisão e exteriorização da cânula pelo dorso do animal. Para minimizar o sofrimento e evitar possíveis infecções, após o término procedimento cirúrgico, os animais receberam 0,4 ml Pentabiótico veterinário (Fontoura-Wyeth, BR) via i.m., e Banamine (ScheringPlough S/A, Brasil), um analgésico profilático via s.c. na dose de $2,5 \mathrm{mg} / \mathrm{Kg} / \mathrm{ml}$ (Hicks et al., 2014).

\subsection{A tarefa comportamental de medo condicionado ao contexto (MCC)}

Após a recuperação da cirurgia de canulação da aorta abdominal, estando no sétimo dia do experimento (a contar o dia da sessão de estresse por restrição como dia 1), ambos os grupos de animas, estressados e não estressados, foram submetidos ao MCC. Para a execução deste paradigma comportamental, foi utilizada uma caixa de $23 \times 20 \times 26 \mathrm{~cm}$ (largura x profundidade x altura, respectivamente) formada por 3 paredes de alumínio e a parte frontal em acrílico, cujo assoalho é constituído por barras metálicas, $23 \times 20 \times 2 \mathrm{~cm}$ cada que conduzem corrente elétrica (Insight Instruments Ribeirão Preto, São Paulo, Brasil). O protocolo experimental consistiu em 3 sessões, com 24 horas de intervalo entre cada sessão: Dia 1: sessão de condicionamento (ou treino), onde os animais foram expostos, individualmente, à caixa de condicionamento para um período de habituação de 120 segundos, e após, foram emitidos 4 choques nas patas em intervalos randômicos (30, 60 e 130 segundos), mantendo o animal na caixa, por um período de 120 segundos, sem a emissão estímulo elétrico antes de devolvê-lo para sua caixa moradia (Lisboa, Sabrina F. et al., 2010). Dia 2: foi realizada a sessão de extinção, que consiste em expor, individualmente, os animais à mesma caixa onde foram previamente condicionados, de forma ininterrupta, na ausência de estímulos elétricos (estímulo condicionado) 
durante o período de 20 min (Suzuki et al., 2004). Dia 3: foi avaliado a retenção da memória de extinção, que consiste na exposição dos animais, individualmente, à mesma caixa utilizada nas sessões do dia 1 e dia 2 , durante um período de 5 min. 0 tempo total de freezing (imobilidade do animal exceto os movimentos respiratórios) foi mensurado em todas as sessões do protocolo experimental como medida comportamental (medida de memória) (Fiorenza et al., 2012). A sessão de teste foi realizada em uma sala de experimento diferente da que será utilizada para o procedimento de condicionamento (Hott et al., 2012), e o aparato experimental foi limpo com o auxílio de papel toalha e álcool $70 \%$, antes e após o uso, com o propósito de que não permanecessem no local pistas olfativas para o próximo animal que será exposto a caixa (Lisboa, Sabrina F. et al., 2010).

\subsection{Drogas}

As drogas utilizadas para aferir a participação dos receptores glicocorticoides e mineralocorticoides no processo de consolidação da extinção da memória de medo contextual foram: Mifepristone (RU 486; antagonista de receptores glicocorticoide) na dose de 10 ng o (Atsak et al., 2012, 2014; Ganon-Elazar e Akirav, 2013; Oliveira, de, Reimer e Brandão, 2014) e Oxprenoato de potássio (RU 28318; antagonista de receptores mineralocorticoide), na dose inicial de 150 ng/lado (McEown e Treit, 2011), ambas administradas em um volume de $100 \mathrm{nl} /$ lado/estrutura. As drogas foram adquiridas da empresa Tocris (Alemanha), e dissolvidos inicialmente em DMSO 100\% para solução de estocagem (armazenadas a $-20^{\circ} \mathrm{C}$ ), e somente antes do experimento serão diluídos em salina $0.9 \%$ nas concentrações final para estudo (com concentração final de DMSO na solução de 1\%). Como controle será administrado o veículo (Salina + DMSO 1\%) (Granjeiro et al., 2011; Oliveira, de, Reimer e Brandão, 2014). A dose inicial das drogas utilizadas foi baseada nos estudos científicos da área. As drogas ou veículo foram administradas em um volume de $100 \mathrm{~nL} /$ lado/estrutura (Lemos, Resstel e Guimarães, 2010; Lisboa, Sabrina F. et al., 2010). 


\subsection{Técnica para a microinjeção intra-cérebro das drogas}

Para a execução da administração das drogas, ou de seus veículos nas regiões encefálicas alvos de estudo, uma guia microinjetora de 33 G (SmallParts, EUA) foi acoplada a um tubo de polietileno PE-10 (.011" x .024" x 10') e este sistema foi conectado a uma microseringa (Hemilton Company, Estados Unidos, modelo KH7001). Durante a execução do procedimento, a guia microinjetora (1 $\mathrm{mm}$ mais longa do que a cânula guia) foi cuidadosamente introduzida na cânula guia de 26 G, implantadas na calota craniana dos animais anteriormente mediante cirurgia estereotáxica, e então a droga ou o veículo (controle) foram dispensados (Granjeiro et al., 2011; Terzian et al., 2014), obedecendo a uma média de velocidade de 0,5 $\mu \mathrm{L} / 30 \mathrm{~s}$ com auxílio de uma bomba de infusão. A guia microinjetora foi mantida por mais $60 \mathrm{~s}$ dentro das cânulas guia, após o término da microinjeção, para evitar o refluxo de líquido, e após, cuidadosamente retirada. Após a verificação de que não houve entupimento na microinjetora, esta foi colocada na outra cânula e o processo foi repetido (infusões bilaterais) (Rosa et al., 2014).

\subsection{Análise histológica do posicionamento das cânulas-guia}

A verificação do posicionamento anatômico das cânulas-guia implantadas nas porções PL e IL do CPFvm dos animais por meio da cirurgia estereotáxica, foi realizada post mortem: 2-4 dias após o término dos procedimentos experimentais, 100 $\mathrm{nL}$ de uma solução de azul de metileno a 4 \% (marcador do sítio da microinjeção) foi administrado aos animais através das mesmas cânulas em que foram microinjetados os compostos farmacológicos ou o veículo nas regiões encefálicas alvo deste estudo. Após 15 min, os animais foram sacrificados pela administração i.p. de uma overdose de anestésico (Uretana $1.25 \mathrm{~g} / \mathrm{Kg}$ ) e decapitados. O cérebro de cada animal foi removido e pós-fixado em formol a $10 \%$ por $24 \mathrm{~h}$ a $4^{\circ} \mathrm{C}$. Após 48 horas, as estruturas cerebrais foram analisadas com auxílio do atlas de Paxinos e Watson (1986) e de um microscópio óptico. Somente os animais onde a localização da mancha de azul de metileno encontrou-se dentro de um raio de $1 \mathrm{~mm}$ do local desejado foram considerados na análise estatística dos dados (Fiorenza et al., 2012; Rosa et al., 2014). 


\subsection{Coleta de estruturas encefálicas}

Alguns experimentos foram executamos até o término da sessão de extinção do ensaio comportamental proposto, 60 ou 90 min após, dependendo da análise, foi realizada a decapitação dos animais por meio de guilhotina, para remoção do cérebro. Os cérebros foram colocados sob uma placa de petri disposta em gelo seco, e banhado com solução fisiológica. Desta forma, amostras de tecido do CPFvm, foram dissecadas, tratadas, e armazenadas em freezer a $-80^{\circ}$ para posterior análise por WB, ou seguida a as instruções do FD Rapid GolgiStain kit, para a análise de neuromorfologia, ambos as técnicas explicadas em maiores detalhes a seguir nesta sessão de materiais e métodos.

\subsection{Coleta de amostras de sangue para dosagem de concentrações séricas de corticosterona}

Foram coletadas amostras de sangue (aproximadamente $300 \mu \mathrm{L}$, em microtubos, através da cânula inserida na aorta abdominal e exteriorizada pelo dorso do animal, mediante a cirurgia de canulação da aorta abdominal. A coleta foi realizada em diferentes tempos: iniciando pelo tempo zero (medida basal), e, após 15, 30, 60 e 120 min do término dos procedimentos comportamentais. As amostras (a serem analisadas em duplicata) foram centrifugadas (5000 rpm/20 min) e o plasma foi então isolado e estocado à $-20^{\circ} \mathrm{C}$ para posterior análise (Ghosal et al., 2014; McKlveen et al., 2013), utilizando o kit de ELISA (Enzo Life Sciences, Inc., Estados Unidos) (Acharjee et al., 2013; Souza et al., 2014).

\subsection{Ensaio imunoenzimático indireto (ELISA)}

Foram coletadas amostras de sangue (aproximadamente $300 \mu \mathrm{l}$, em microtubos, através da canulação da aorta abdominal (metodologia descrita nesta sessão no item 3.5.). A coleta foi realizada em diferentes tempos: Iniciando pelo tempo zero (medida basal), e, após 15, 30, 60 e 120 min do término dos procedimentos comportamentais. As amostras (analisadas em duplicatas) (Mandela et al., 2014), foram centrifugadas (5000 rpm/15 min) e o plasma então isolado e estocado à $-20^{\circ} \mathrm{C}$ até o momento da análise (Ghosal et al., 2014; McKlveen et al., 2013). A aferição da 
concentração plasmática de corticosterona foi realizada utilizando-se um kit de ELISA (Enzo Life Sciences, Inc., Estados Unidos) (Acharjee et al., 2013; Souza et al., 2014).

\subsection{Técnica de GolgiStain-Cox}

Para a análise da densidade de espinhos dendríticos nas camadas II e III do CPFvm, foi empregada a técnica de Golgi. Após 1 hora do término da sessão de teste da tarefa de MCC, animais sob as condições estressados e não estressados foram submetidos a eutanásia por guilhotina. O cérebro de cada animal foi removido e preservado, fora do alcance da luz, em soluções sequentes do kit FD Rapid GolgiStain, totalizando 13 dias. Após este período, os hemisférios de cada animal foram enviados para Milão, Itália, e realizados, com auxílio de um micrótomo (Gibb e Kolb, 1998), cortes histológicos de $200 \mu \mathrm{m}$, que foram dispostos em laminas de microscopias revestidos de gelatina. A seguir, neurônios piramidais das camadas II e III do CPFvm foram identificados, e espinhos dendríticos dos domínios basal e apical destes neurônios foram fotografados, para posterior análise em software específico Imaris (Risher et al., 2014).

\subsection{Western Blotting (WB)}

Para verificar a expressão dos receptores mineralocorticoide e glicocorticoide no CPFvm, 90 min após o término da sessão de extinção na tarefa de MCC, uma amostra de animais sob as condições estressados, não estressados e naive, foram decapitados, e o cérebro rapidamente removido e colocado sob uma placa de petri disposta em gelo seco, e banhado com solução fisiológica, para que então a área do CPFvm fosse dissecada e imediatamente estocada em freezer $-80^{\circ} \mathrm{C}$ até o momento da análise. A técnica de Western Blotting foi planejada para ser executada conforme descrito em Han e colaboradores (Han, Ding e Shi, 2014) e Navarro-Zaragoza e colaboradores (Navarro-Zaragoza et al., 2012). A expressão de GAPDH (Glyceraldehyde 3-phosphate dehydrogenase) foi a medida determinada como normalizador (controle), em todas as amostras. Foi determinado para a análise do ensaio a utilização do software ImageJ (NIH). 


\subsection{Protocolos experimentais}

As tarefas comportamentais foram realizadas durante a fase clara do ciclo dos animais, no período matutino, evitando o período vespertino onde há elevação dos níveis de corticosterona em roedores (pico circadiano) (Kolber, Wieczorek e Muglia, 2008), exceto quando em cumprimento do objetivo específico que pretendia verificar o perfil de extinção de memória aversiva durante o pico circadiano de corticosterona, em animais estressados e não estressados. Todos os protocolos comportamentais descritos a seguir foram conduzidos em salas específicas que permitam o registro da REC durante a execução dos ensaios. Antes de cada procedimento os animais foram transportados da sala de alojamento à sala reservada ao experimento e permaneceram neste ambiente por um período de 30 minutos para aclimatação e, após o término, foram submetidos aos protocolos experimentais de maneira randômica, e após, devolvidos à sua caixa moradia e novamente transportados à sala de alojamento.

3.14.1. Protocolo experimental 1: 0 papel do estresse agudo no processo de extinção da memória de condicionamento aversivo: Perfil de extinção da memória de medo condicionado ao contexto em animais estressados e não estressados, submetidos a um estresse agudo inescapável prévio ao MCC em um protocolo de 9 dias com treino de 4 choques de $0,85 \mathrm{~mA} / 1$ s e sessão de extinção de $20 \mathrm{~min}$

No dia 1, um grupo de animais foi submetido a uma sessão única de estresse por restrição durante 1 hora e um outro grupo de animais permaneceu no biotério em condições habituais. Após este procedimento, os animas permaneceram em suas caixas moradias durante 5 dias sem qualquer estímulo. No dia 7, ambos os grupos (animais estressados e não estressados) foram submetidos ao paradigma comportamental de MCC: Dia 7: Para a sessão de condicionamento (ou treino), os animais foram expostos, individualmente, à caixa de condicionamento por 120s para habituação, seguidos de 4 choques nas patas de $0,85 \mathrm{~mA}$ com duração de $1 \mathrm{~s}$ e intervalos variando de 30s à 90s (randomizado), mantendo-se o animal na caixa, após a emissão do último estímulo elétrico, durante 120s. Dia 8: foi realizada a sessão de extinção, que consistiu em expor, individualmente, os animais à mesma caixa onde 
foram previamente condicionados, durante 20 min (Fiorenza et al., 2012; Rosa et al., 2014), de forma ininterrupta, na ausência de estímulos elétricos (estímulo condicionado). Dia 9: foi avaliado a retenção da memória de extinção, que consistiu em expor os animais, individualmente, à mesma caixa utilizada nas sessões do dia 1 e dia 2, durante $5 \mathrm{~min}$. Este ensaio foi realizado com a ocultação dos grupos experimentais ao examinador.

\subsubsection{Protocolo experimental 2: Participação dos receptores glicocorticoides,} presentes na porção IL ou PL do CPFvm no processo de consolidação da extinção de memória aversiva, em animais estressados e não estressados

Foi executado o protocolo de MCC conforme descrito acima (item 3.14.1.), contudo, imediatamente após o término da sessão de extinção os animais, estressados e não estressados, receberam uma administração bilateral, na porção PL e/ou IL do CPFvm, do antagonista de receptores para glicocorticoides na concentração de 10ng (Atsak et al., 2014; Ganon-Elazar e Akirav, 2013; Oliveira, de, Reimer e Brandão, 2014), ou veículo, ambos administrados em um volume de 100 nl/lado (Lemos, Resstel e Guimarães, 2010; Lisboa, Sabrina F. et al., 2010).

\subsubsection{Protocolo experimental 3: Participação dos receptores mineralocorticoides, presentes na porção IL ou PL do CPFvm no processo de consolidação da extinção de memória aversiva, em animais estressados e não estressados}

Foi executado o protocolo de MCC conforme descrito no item 3.14.1. desta sessão de protocolos, contudo, imediatamente após o término da sessão de extinção os animais, estressados e não estressados, receberam uma administração bilateral, na porção PL e/ou IL do CPFvm, do antagonista de receptores para mineralocorticoides na concentração de $150 \mathrm{ng}$, ou veículo, ambos administrados em um volume de $100 \mathrm{nl} /$ lado (Lemos, Resstel e Guimarães, 2010; Lisboa, Sabrina F. et al., 2010). 
3.14.4. Protocolo experimental 4: Investigação do perfil de extinção da memória aversiva quando da realização da sessão de extinção durante o pico do ciclo circadiano de corticosterona dos animais

Foi executado o protocolo de MCC conforme descrito no item 3.14.1. desta sessão de protocolos. Contudo, a sessão de extinção foi realizada no período vespertino, quando há um aumento nos níveis plasmáticos de corticosterona em roedores.

3.14.5. Protocolo experimental 5: Ensaio experimental para a coleta de amostras de sangue para aferição dos níveis plasmáticos de corticosterona

Foi executado o protocolo de MCC conforme descrito item 3.14.1. desta sessão de protocolos. Imediatamente após a sessão de estresse por restrição ou 0, 15, 30, 60 e 120 após as sessões de condicionamento, extinção e teste da retenção da memória de extinção, foram realizadas coletas de amostras de sangue dos animais para aferir os níveis de corticosterona plasmática dos mesmos. A coleta e o processamento das amostras foram executados conforme os itens 3.10 e 3.11 descritos na sessão de materiais e métodos desta Tese.

\subsubsection{Protocolo experimental 6: Ensaio experimental para coleta do encéfalo} dos animais para a análise de GolgiStain, ou retirada específica de amostras do córtex pré-frontal ventromedial para análise de WB

Foi executado o protocolo de MCC conforme descrito no protocolo 1 desta sessão de protocolos. Contudo, o ensaio comportamental foi conduzido somente até o término da sessão de extinção, quando após 90 min um grupo experimental foi submetido a eutanásia para remoção do cérebro e coleta específica da região ventromedial do córtex pré-frontal para a análise de WB. Outro grupo foi submetido a eutanásia 60 min após o término da sessão de extinção para a coleta do cérebro para a análise de GolgiStain. As amostras foram processadas conforme descrição no item 3.9 da sessão de materiais e métodos desta Tese. 


\subsection{Análise estatística dos resultados}

A análise dos dados foi realizada com o auxílio dos programas Excel para Windows e GraphPad Software ${ }^{\circ}$. O comportamento de imobilidade (freezing) dos animais foi expresso como percentual do tempo total de imobilidade em relação ao tempo total de exposição dos animais a caixa (contexto aversivo), sendo analisado por meio de testes de estatística paramétrica, análise de variância (ANOVA) de uma ou duas vias, seguido do contraste adequado (Callegari-Jacques, 2007). Para análise dos dados verificados na sessão de condicionamento e na sessão de extinção, foi empregado ANOVA de duas vias, tendo como fatores a condição (animais estressados e não estressados) e o tempo, e em caso de interação significativa entre os fatores aplica-se o pós-teste de Bonferroni, para comparar a variação em cada condição. Já os dados obtidos ao teste da retenção da memória de extinção, ou análise bioquímicas e neuromorfológicas foram analisados pelo teste $\mathrm{t}$ de Student, não pareado, quando da comparação entre dois grupos, ou quando da comparação entre mais de dois grupos foi aplicado ANOVA de uma via, seguido do pós-teste de Newman-Keuls. Os dados foram expressos em média \pm erro padrão da média ( $\pm E P M)$, e os valores de $p<0,05$ foram considerados estatisticamente significantes. 


\section{RESULTADOS}

\subsection{O papel do estresse agudo no processo de extinção da memória de condicionamento aversivo}

Durante a aquisição da memória de condicionamento os animais estressados $(n=10)$ e não estressados $(n=10)$ apresentam um progressivo aumento na resposta de freezing ao longo do tempo $\left(\mathrm{F}_{(4,90)}=79.66, \mathrm{p}<, 00001\right)$, não havendo interação entre os grupos $\left(F_{(4,90)}=0.55, p=0.6981\right)$ ou efeito do fator condição $\left(F_{(1,90)}=2.98, p=0,0875\right)$. Os animais submetidos ao estresse por restrição durante $1 \mathrm{~h}$ apresentaram aumento na expressão da memória de condicionamento aversivo durante a sessão de extinção $\left(F_{(1,72)}=14.78, p<, 001\right)$, mas ambos os grupos adquirirem a memória de extinção ao longo da sessão $\left(F_{(3,72)}=14.02, p<0,001\right)$ e não há interação entre os grupos $\left(F_{(3,72)}=0.23, p=0,8784\right)$. Já na sessão de teste de retenção da memória de extinção, os animais expostos ao estresse por restrição durante 1 hora apresentaram déficit na consolidação da memória de extinção $\left(F_{(5,59)}=15.76, p<0,001\right.$ - Figura $\left.1 D\right)$. No gráfico 1D podemos ver em detalhe, pela representação em colunas dos dados, que ocorre a aquisição da memória de extinção de ambos os grupos (estressados e não estressados), bem como o aumento na expressão da resposta ao MCC. 


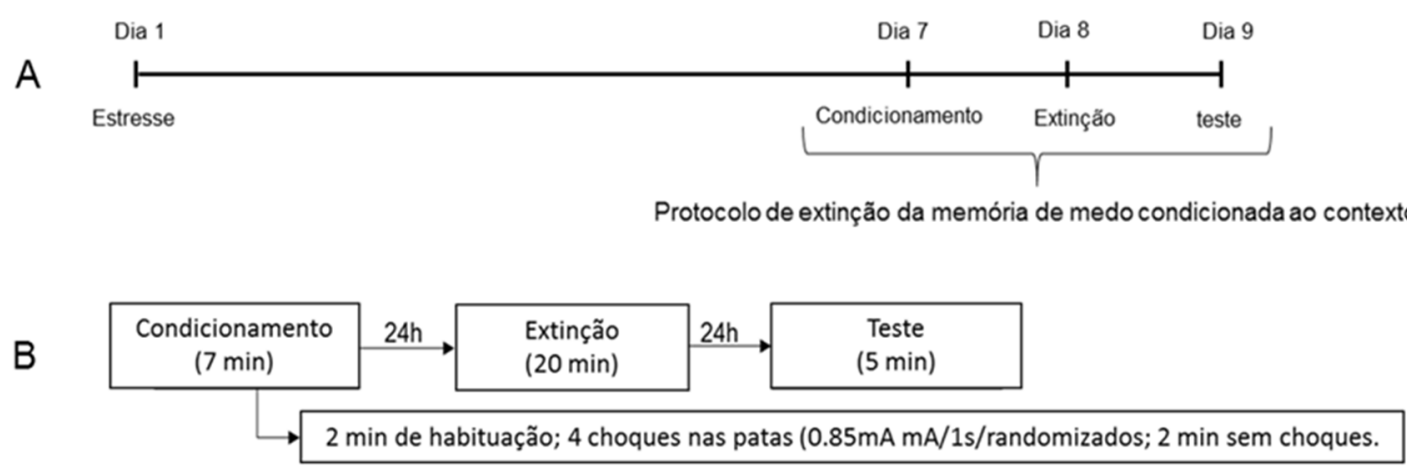

$-0-$ A nimais não submetidos ao estresse por restrição
C $\square-$ A nimais submetidos ao estresse por restrição durante $1 \mathrm{~h}$

Condicionamento

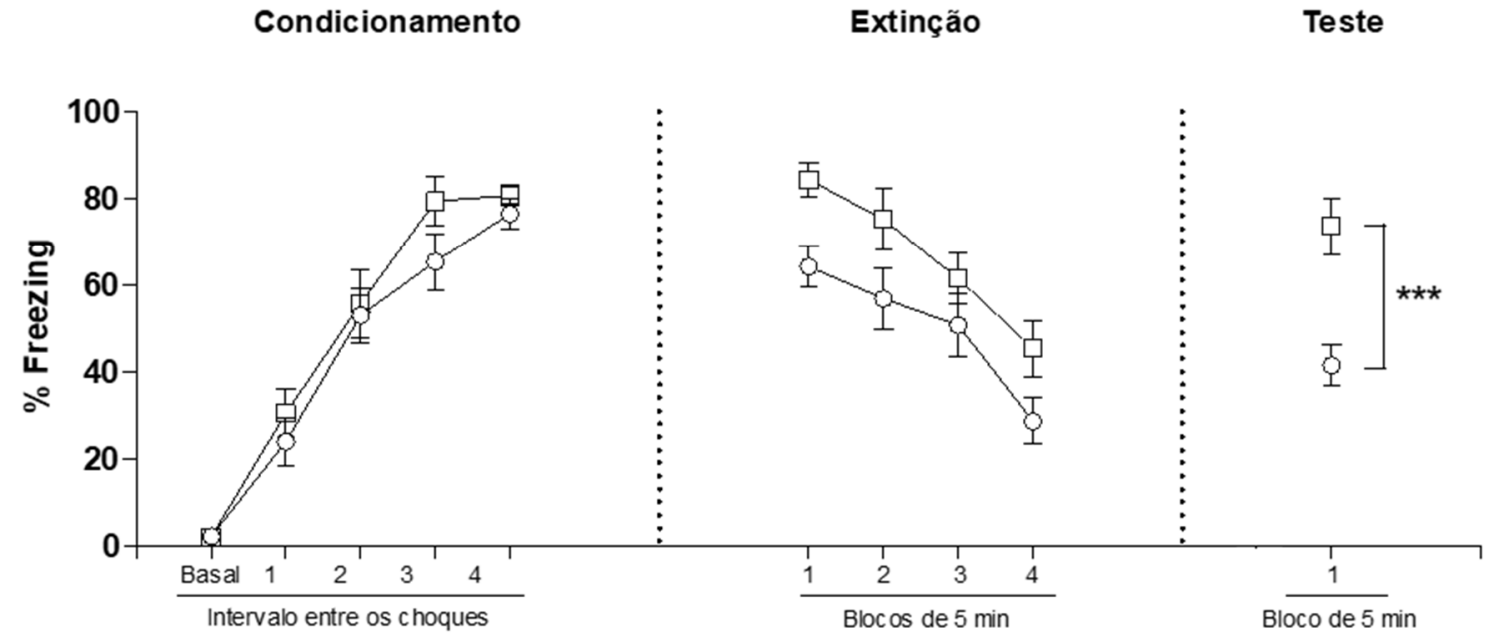

Extinção

Teste

D Animais não submetidos ao estresse por restrição

$\ldots$ Animais submetidos ao estres se por restrição durante $1 \mathrm{~h}$
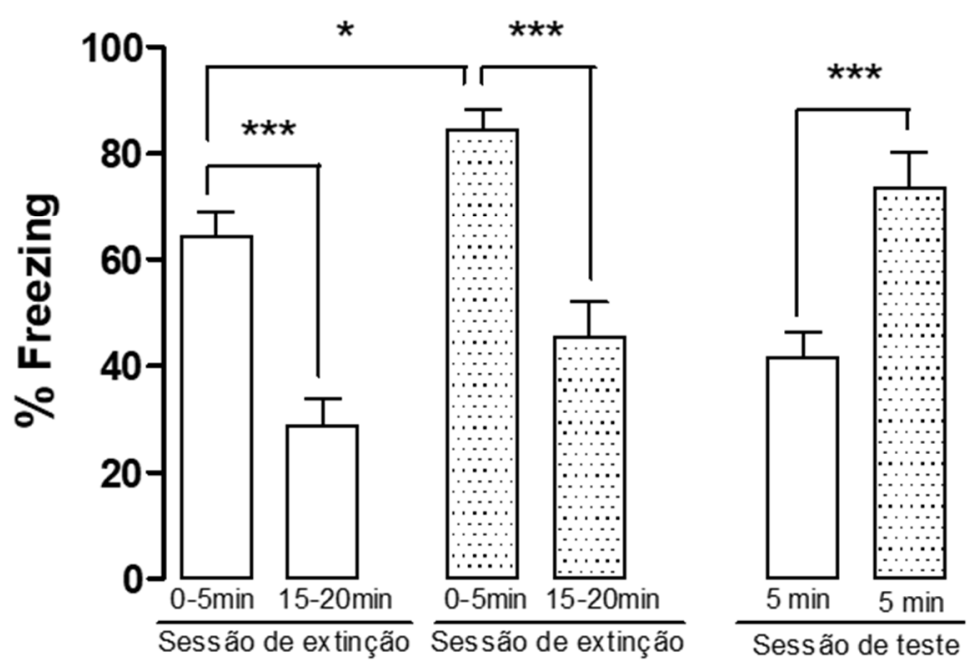
Figura 1. Efeito sustentado do estresse agudo sobre o perfil de extinção da memória de medo condicionado ao contexto. (A). Representação esquemática do intervalo de tempo entre os procedimentos comportamentais. (B). Representação esquemática do protocolo de extinção da memória de condicionamento contextual. (C). Os símbolos representam a média e as barras \pm o EPM. $n=10$ por grupo. ${ }^{* * *} p<0,05=$ grupo estressado por $1 \mathrm{~h}$ versus grupo não estressado. (D) Representação em gráfico de colunas dos dados apresentados na figura 1C analisando os 5 min iniciais da sessão de extinção versus os 5 minutos finais da sessão de extinção em animais não estressados e não estressados, demonstrando que a extinção ocorre em ambos os grupos. Representação em coluna dos dados provenientes da sessão de teste da retenção da memória de extinção. Os grupos foram submetidos a análise de variância ANOVA de uma via seguido do pós-teste de Newman-Keuls em que ${ }^{*} p<0,05 ;{ }^{* *} p<0,01 ;{ }^{* * *} p<0,001$.

\subsection{Participação dos receptores para glicocorticoides, presentes na porção IL do CPFvm, sobre a consolidação da extinção de memória aversiva em animais estressados e não estressados}

Animais submetidos ao estresse por restrição e animais não estressados foram subdivididos em 4 grupos: animais não estressados e que receberam a microinjeção de veículo $(n=12)$; animais não estressados que receberam a microinjeção de Mifepristone $(n=10)$; animais estressados que receberam a microinjeção de veículo $(n=10)$; e animais estressados que receberam microinjeção de Mifepristone $(n=12)$. Todos estes grupos foram condicionados no protocolo experimental 2, descrito item 3.14.2., da sessão de materiais e métodos desta Tese, representado nos desenhos esquemático $2 \mathrm{~A}$ e $2 \mathrm{~B}$. Conforme podemos observar no gráfico $2 \mathrm{C}$, durante a aquisição da memória de condicionamento os animais estressados e não estressados apresentam um progressivo aumento na resposta de freezing ao longo do tempo $\left(\mathrm{F}_{44}\right.$, $160)=266.15, p<, 00001)$, não havendo interação entre os grupos $\left(F_{(12,160)}=0.96\right.$, $p=0,4932)$ ou efeito do fator condição $\left(F_{(3,160)}=1.08, p=0,3678\right)$. Os animais estressados por 1 hora apresentaram um aumento na expressão do medo condicionado, observado durante a sessão de extinção $\left(F_{(3,120)}=3.37, p>0,05\right)$, e ambos os grupos apresentaram aquisição da memória de extinção ao longo do tempo $\left(F_{(3,120)}=146.44, p<0,0001\right)$, não havendo interação entre os grupos $\left(F_{(9,120)}=1.90\right.$, $p=0,0580$ ). Como já visto no resultado obtido na execução do protocolo 1 , os animais que foram expostos ao estresse por restrição prévio ao condicionamento, durante 1 hora, apresentaram um déficit na consolidação da extinção da memória de medo 
condicionado ao contexto $\left(F_{(3,43)}=12.51, p<0,0047\right)$. Contudo, quando houve a administração bilateral do antagonista de receptores para glicocorticoides Mifepristone (ou RU486) na dose 10ng/lado, microinjetado na porção IL do CPFvm imediatamente após a sessão de extinção, o déficit na consolidação da memória de extinção promovido pelo estresse agudo foi revertido, sem causar efeito sobre a consolidação da memória de extinção em animais não estressados $\left(F_{(3,43)}=12.51\right.$, $p<0,05)$.
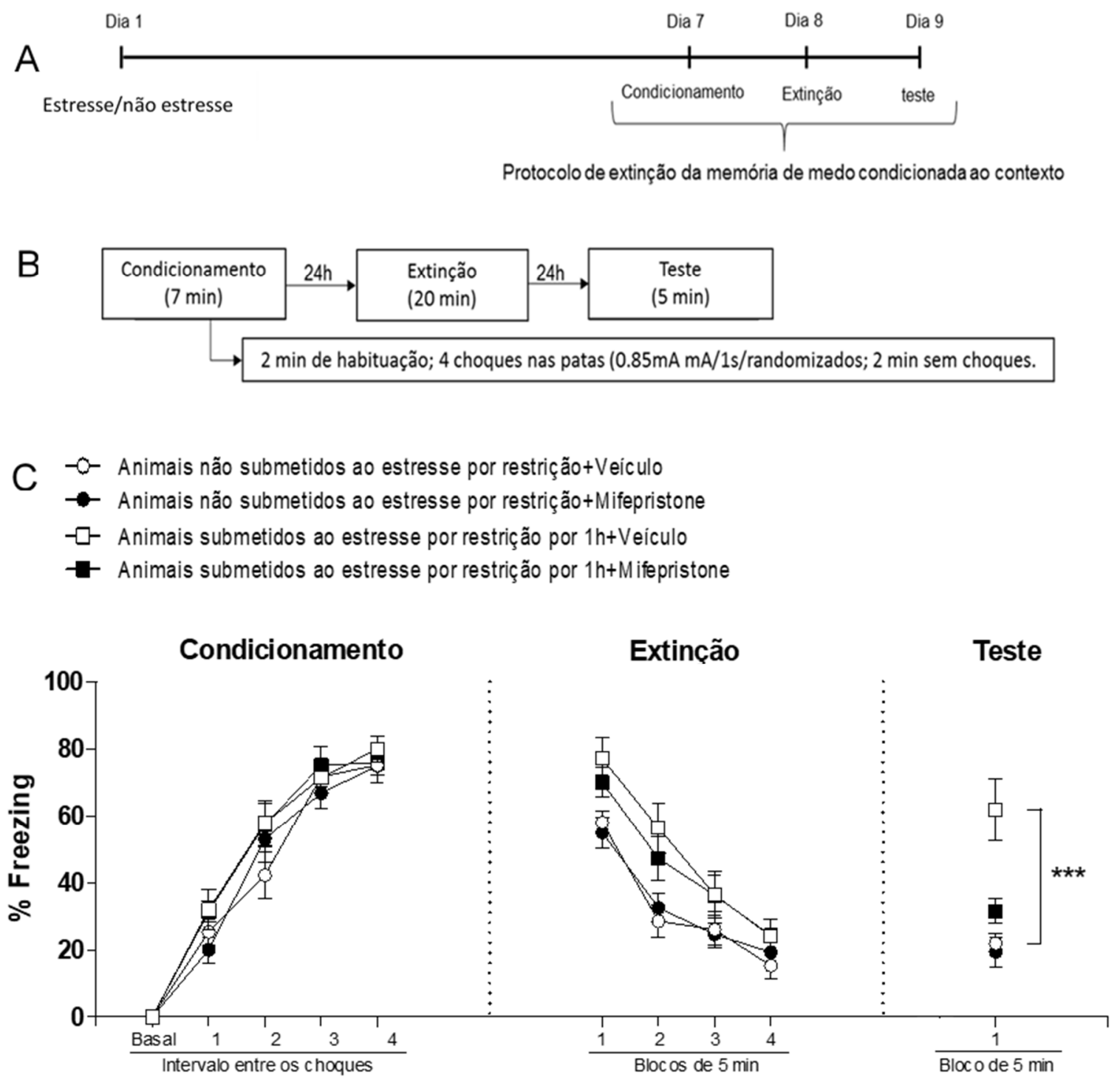

Figura 2. Efeito da administração do antagonista de receptores para glicocorticoides na porção IL do CPFvm sobre a consolidação da extinção de memória aversiva em animais estressados e não estressados. (A). Representação esquemática do intervalo de tempo entre os procedimentos comportamentais. (B). Representação esquemática do protocolo de extinção da memória de condicionamento aversivo. (C). Os símbolos representam a média e as barras \pm o EPM. $n=10-12$ por grupo. ${ }^{* *} p<0,0001=$ grupo estressado por $1 \mathrm{~h}$ que recebeu administração de veículo versus grupo não 
estressado que recebeu veículo. O grupo de animais estressado por 1 h e que recebeu a administração de Mifepristone não apresentou diferença estatística significativa em comparação ao grupo de animais que não foram estressados e receberam a administração de veículo. (ANOVA de uma via, seguido do pós-teste de Newman-Keuls).

\subsection{Participação dos receptores para glicocorticoides, presentes na porção PL do CPFvm, sobre a consolidação da extinção de memória aversiva em animais estressados e não estressados}

Animais submetidos ao estresse por restrição e animais não estressados foram subdivididos em 4 grupos: animais não estressados e que receberam a microinjeção de veículo $(n=12)$; animais não estressados e que receberam a microinjeção de Mifepristone $(n=12)$; animais estressados e que receberam a microinjeção de veículo $(n=8)$; e animais estressados e que receberam microinjeção de Mifepristone $(n=7)$. foram condicionados no protocolo experimental descrito item 3.14.2., Protocolo 2, da sessão de materiais e métodos desta tese, representado nos desenhos esquemático 3A e 3B, e cuja resposta comportamental foi primeiramente observada e representada no gráfico $1 \mathrm{C}$, desta sessão de resultados. Conforme podemos observar no gráfico $3 \mathrm{C}$, os resultados alcançados foram semelhantes aos encontrados com a administração de Mifepristone na porção IL do CPFvm. Durante a aquisição da memória de condicionamento os animais estressados e não estressados apresentam um progressivo aumento na resposta de freezing ao longo do tempo $\left(F_{(4,140)}=226.45\right.$, $p<0,0001)$, não havendo interação entre os grupos $\left(F_{(12,140)}=0.24, p=0,9963\right)$ ou efeito do fator condição $\left(F_{(3,140)}=0.09, p=0,9649\right)$. Os animais estressados por 1 hora apresentaram um aumento na expressão do medo condicionado, quando expostos novamente a caixa de condicionamento para a sessão de extinção $\left(F_{(3,105)}=3.49\right.$, p=0,0257), e ambos os grupos apresentaram aquisição da memória de extinção ao longo do tempo $\left(F_{(3,105)}=121.50\right.$, $\left.p<0,0001\right)$, não havendo interação entre os grupos $\left(F_{(9,105)}=2,01 p=0,0447\right)$. Como já visto na padronização deste protocolo, os animais que foram expostos ao estresse por restrição prévio ao condicionamento, durante 1 hora, apresentaram um déficit na consolidação da extinção da memória de medo condicionado ao contexto $\left(\mathrm{F}_{(3,38)}=4.905, \mathrm{p}<0,05\right)$. Contudo, quando houve a administração bilateral do antagonista de receptores para glicocorticoides Mifepristone (ou RU486) na dose 10ng/lado, microinjetado na porção PL do CPFvm 
imediatamente após a sessão de extinção, o déficit na consolidação da memória de extinção promovido pelo estresse agudo foi revertido, sem causar efeito sobre a consolidação da memória de extinção em animais não estressados $\left(F_{(3,38)}=4.905\right.$, $p<0,05)$.
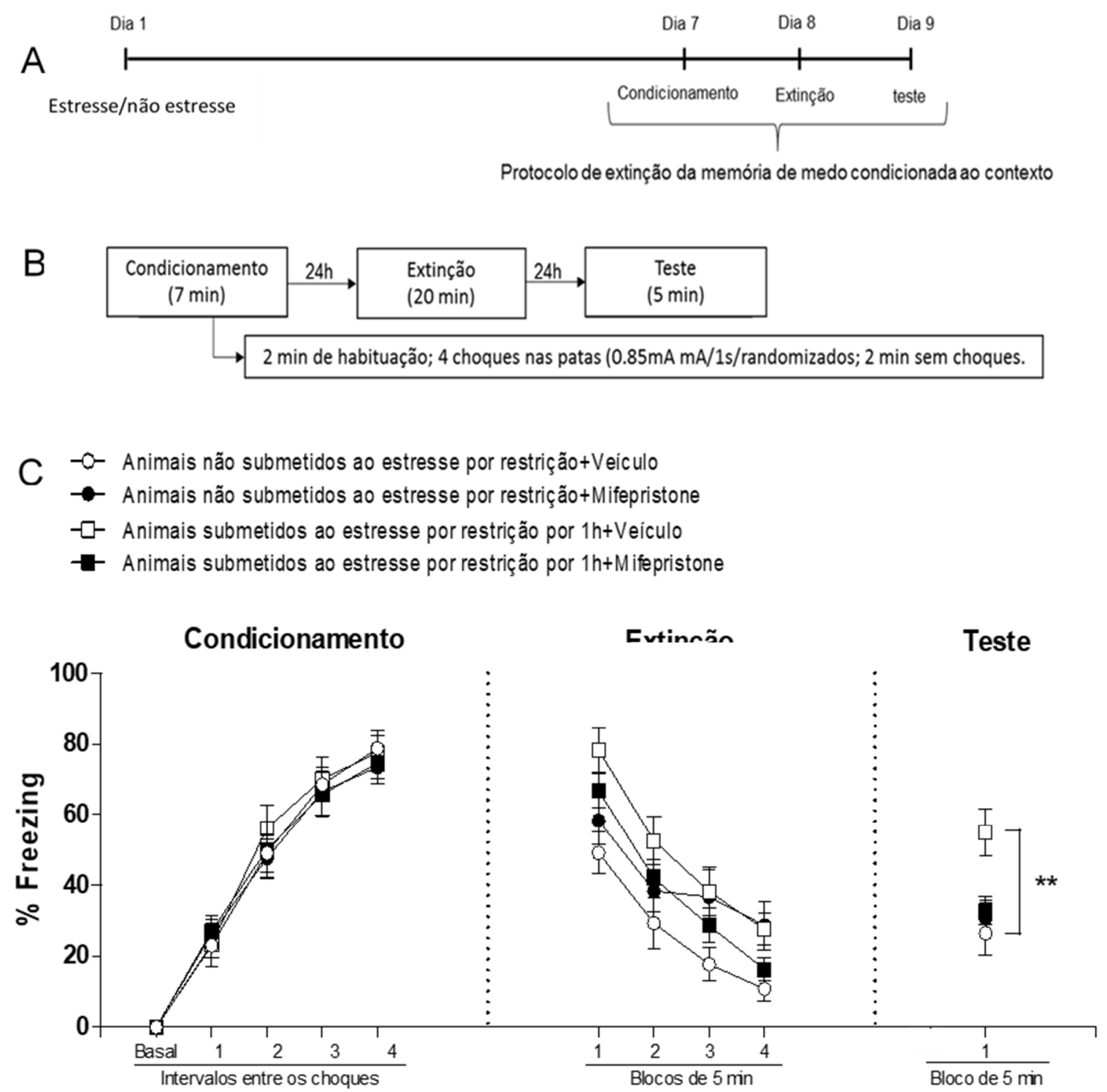

Figura 3. Efeito da administração do antagonista de receptores para glicocorticoides na porção PL do CPFvm sobre a consolidação da extinção de memória aversiva em animais estressados e não estressados. (A). Representação esquemática do intervalo de tempo entre os procedimentos comportamentais. (B). Representação esquemática do protocolo de extinção da memória de condicionamento aversivo. (C). Os símbolos representam a média e as barras \pm 0 EPM. $n=7-12$ por grupo. ${ }^{* *} p<0,001=$ grupo estressado por $1 \mathrm{~h}$ que recebeu administração de veículo versus grupo não estressado que recebeu veículo. O grupo de animais estressado por 1 h e que recebeu a administração de Mifepristone não apresentou diferença estatística significativa em comparação ao grupo de animais 
que não foram estressados e receberam a administração de veículo. (ANOVA de uma via, seguido do pós-teste de Newman-Keuls).

\subsection{Participação dos receptores para mineralocorticoides, presentes na porção IL do CPFvm, sobre a consolidação da extinção de memória aversiva em animais estressados e não estressados}

Animais submetidos ao estresse por restrição e animais não estressados foram subdivididos em 4 grupos: animais não estressados e que receberam a microinjeção de veículo $(n=4)$; animais não estressados e que receberam a microinjeção de Oxpreonato $(n=4)$; animais estressados e que receberam a microinjeção de veículo $(n=4)$; e animais estressados e que receberam microinjeção de Oxprenoato $(n=5)$. foram condicionados no protocolo comportamental descrito item 3.14.3., protocolo experimental 3, da sessão de materiais e métodos desta tese, representado nos desenhos esquemático 4A e 4B, cuja resposta comportamental foi primeiramente observada e representada no gráfico $1 \mathrm{C}$ ). Conforme podemos observar no gráfico $1 \mathrm{C}$, durante a aquisição da memória de condicionamento os animais estressados e não estressados apresentam um progressivo aumento na resposta de freezing ao longo do tempo $\left(F_{(4,65)}=108.20\right.$, $\left.p<0,0001\right)$, não havendo interação entre os grupos $\left(F_{(12,65)}=1.12, p=0,3572\right)$ ou efeito do fator condição $\left(F_{(3,65)}=1.45, p=0.2370\right)$. Os animais estressados por 1 hora apresentaram um aumento na expressão do medo condicionado, observado durante a sessão de extinção $\left(F_{(3,52)}=18.69, p>0,0001\right)$, e ambos os grupos apresentaram aquisição da memória de extinção ao longo do tempo $\left(F_{(3,52)}=25.18, p<0,0001\right)$, não havendo interação entre os grupos $\left(F_{(9,52)}=0.50\right.$, $p=0,8708$ ). Como já visto na padronização deste protocolo, os animais que foram expostos ao estresse por restrição prévio ao condicionamento, durante 1 hora, apresentaram um déficit na consolidação da extinção da memória de medo condicionado ao contexto $\left(\mathrm{F}_{(7,33)}=6.686, \quad \mathrm{p}<0,05\right)$. A administração bilateral do antagonista de receptores para mineralocortioides Oprenoato (ou RU23318) na dose 150ng/lado, microinjetado na porção IL do CPFvm imediatamente após a sessão de extinção, ao contrário do que observamos com o antagonista para glicocorticoides Mifepristone, não reverteu o déficit na consolidação da memória de extinção promovido pelo estresse agudo. Ou seja, os animais estressados continuam a 
apresentar déficit na consolidação da extinção da memória aversiva após o tratamento $\left(F_{(7,33)}=6.686, p<0,05\right)$.
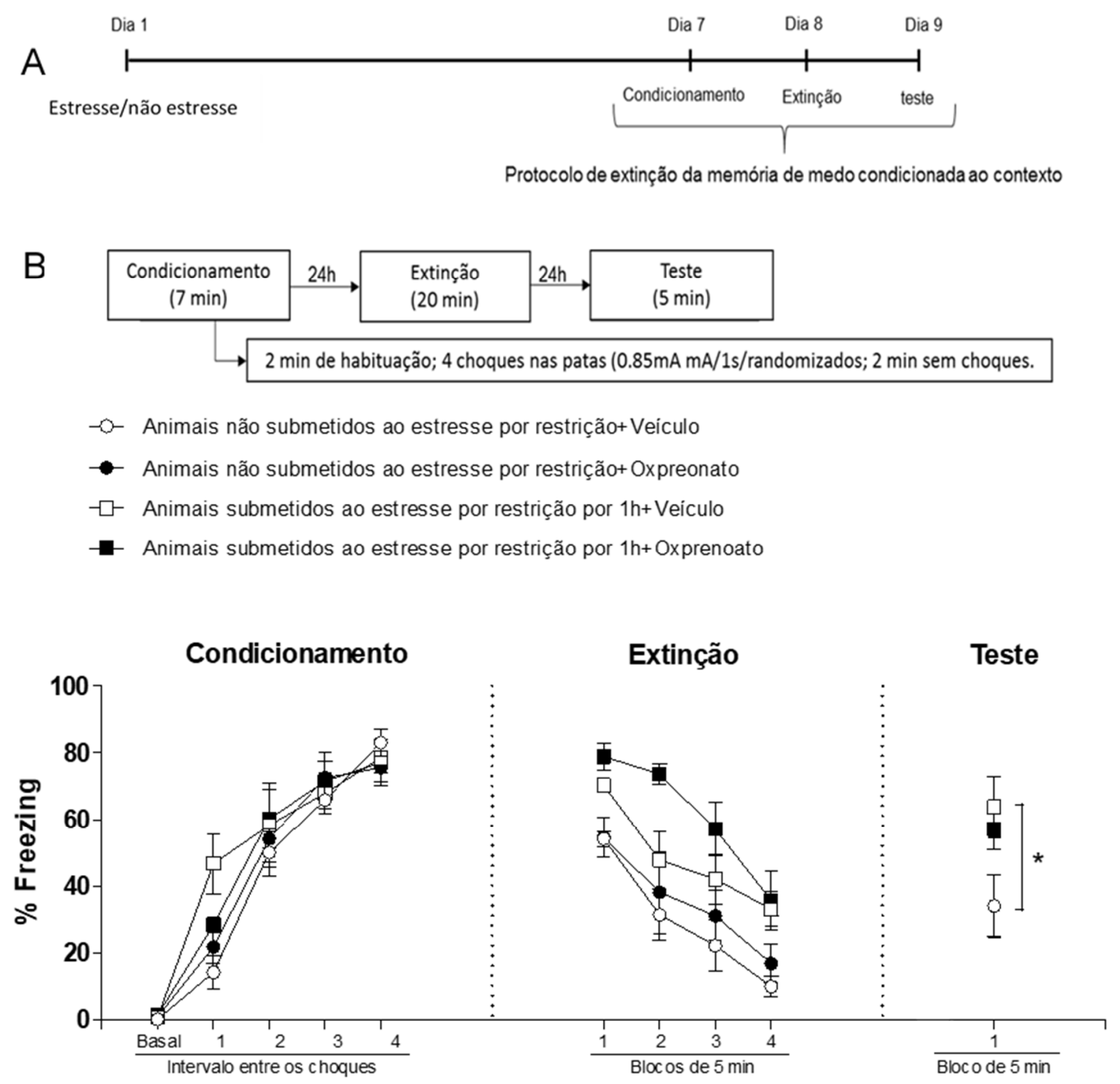

Figura 4. Efeito da administração do antagonista de receptores para mineralocortioides na porção IL do CPFvm sobre a consolidação da extinção de memória aversiva em animais estressados e não estressados. (A). Representação esquemática do intervalo de tempo entre os procedimentos comportamentais. (B). Representação esquemática do protocolo de extinção da memória de condicionamento aversivo. (C). Os símbolos representam a média e as barras \pm o EPM. $n=4-5$ por grupo. ${ }^{*} p<0,05=$ grupo estressado por $1 \mathrm{~h}$ que recebeu administração de veículo versus grupo não estressado que recebeu veículo. O grupo de animais estressado por 1 h e que recebeu a administração de Oxprenoato apresentou diferença estatística significativa, $p>0,05$, em comparação ao grupo de animais que não foram estressados e receberam a administração de veículo ou Oxprenoato. (ANOVA de uma via, seguido do pós-teste de Newman-Keuls). Observação: resultado parcial, precisa ser completado o $\mathrm{n}$ experimental. 


\subsection{Investigação do perfil de extinção da memória aversiva quando da realização da sessão de extinção durante o pico do ciclo circadiano de corticosterona dos animais}

Animais submetidos ao estresse por restrição e animais não estressados foram condicionados no protocolo comportamental descrito item 3.14.4. Protocolo 4, da sessão de materiais e métodos desta tese, representado nos desenhos esquemático $5 \mathrm{~A}$ e 5B. Contudo, ao contrário dos outros experimentos realizados no período matutino, neste caso, somente a performance da extinção foi realizada no período vespertino (sendo o treino e o teste realizados no período matutino) obtivemos os seguintes resultados: Durante a aquisição da memória de condicionamento os animais estressados $(n=9)$ e não estressados $(n=9)$ apresentam um progressivo aumento na resposta de freezing ao longo do tempo $\left(F_{(4,80)}=40,79, p<, 00001\right)$, não havendo interação entre os grupos $\left(F_{(4,80)}=0.39, p=0,8142\right)$ ou efeito do fator condição $\left(F_{(1,80)}=0.71, p=0,4028\right)$. Ambos os grupos durante a performance de extinção do medo condicionado apresentaram níveis alto de freezing não havendo diferença entre os grupos $\left(F_{(1,64)}=0.34, p=0,5639\right)$, mas ambos os grupos adquirirem a memória de extinção ao longo da sessão $\left(F_{(3,64)}=21.64 p<0,0001\right)$ e não há interação entre os grupos $\left(F_{(3,64)}=0.26, p=0,8513\right)$. Ambos os grupos apresentaram altos níveis de freezing durante a sessão de teste, não havendo diferença estatística entre eles, o que demonstra déficit na consolidação da memória de extinção de ambos os grupos $(t=3.3957 \mathrm{df}=16, \mathrm{p}=6975)$. 


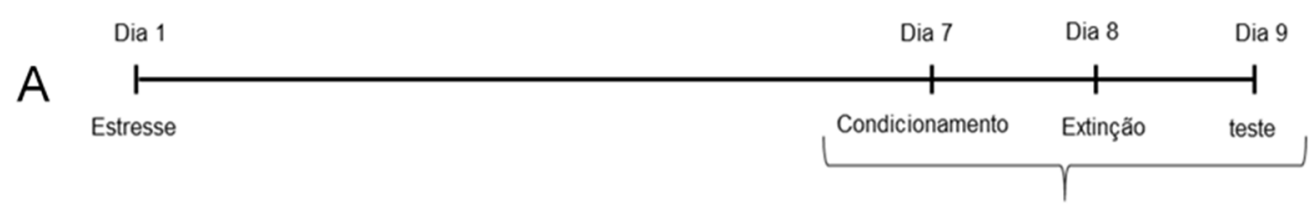

Protocolo de extinção da memória de medo condicionada ao contexto

B

\begin{tabular}{|c|c|c|c|c|}
\hline $\begin{array}{l}\text { Condicionamento } \\
\text { (7 min) }\end{array}$ & $24 \mathrm{~h}$ & $\begin{array}{l}\text { Extinção } \\
\text { (20 min) }\end{array}$ & $24 \mathrm{~h}$ & $\begin{array}{l}\text { Teste } \\
\text { (5 min) }\end{array}$ \\
\hline
\end{tabular}

2 min de habituação; 4 choques nas patas $(0.85 \mathrm{~mA} \mathrm{~mA} / 1 \mathrm{~s} /$ randomizados; $2 \mathrm{~min}$ sem choques.

C $\quad-$ Animais não estressados

- Animais submetidos ao estresse por restrição por $1 \mathrm{~h}$

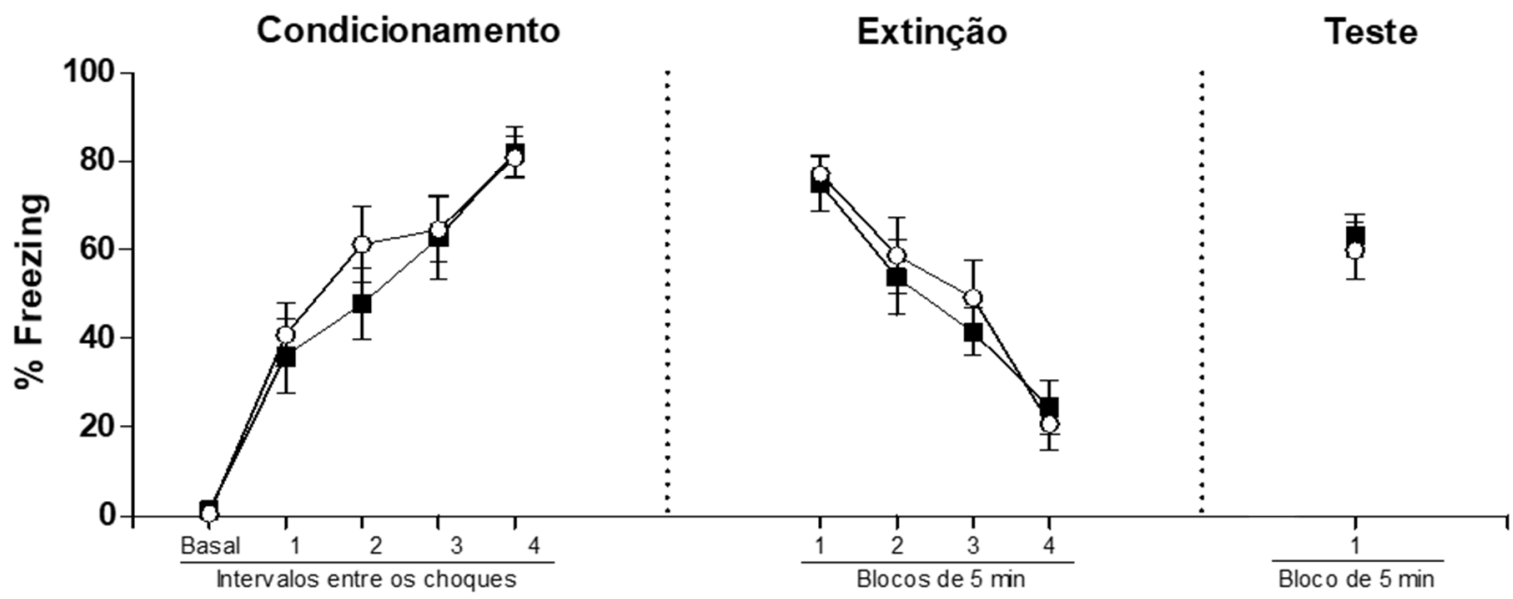

Figura 5. Perfil de extinção da memória de medo condicionado ao contexto e da retenção da memória de extinção em animais estressados e não estressados submetidos ao protocolo experimental 4, sendo a sessão de extinção realizada durante o pico do ciclo circadiano de corticosterona dos animais (período vespertino). (A). Representação esquemática do intervalo de tempo entre os procedimentos comportamentais. (B). Representação esquemática do protocolo de extinção da memória de condicionamento aversivo (C). Os símbolos representam a média e as barras \pm 0 EPM. $n=9$ por grupo. Não houve diferença entre os grupos estressados e não estressados durante a sessão de condicionamento $\left(F_{(1,80)}=0.71, p=0,4028\right)$, extinção $\left(F_{(1,64)}=0.34, p=0,5639\right)$ e teste $(t=3.3957 d f=16$, $\mathrm{p}=6975)$. 


\subsection{Análise dos níveis plasmáticos de corticosterona após o estresse por restrição e após as sessões de condicionamento, extinção e teste da retenção da memória de extinção}

As amostras foram processadas, e os resultados referentes ao tempo 0 após 0 estresse por restrição e aos tempos de 0,15, 30, 60 e 120 min após as sessões de condicionamento, extinção e teste ainda estão sob análise no período da defesa desta Tese.

\subsection{Análise da densidade de espinhos dendríticos no CPFvm, após o término da sessão de extinção na tarefa de MCC}

Esta análise foi proposta no projeto inicial que deu origem a esta Tese e também foi proposta para a FAPESP para obtenção de Bolsa de Estágio de Pesquisa no Exterior (BEPE). No projeto enviado à FAPESP e de conhecimento dos orientadores do Brasil e do Exterior, foi acordado que o ensaio comportamental, a coleta das amostras e o processamento inicial para este ensaio seriam realizados no Brasil e as amostras enviadas ao laboratório no exterior para análise de GolgiStain e posterior avaliação por software adequado. Enquanto aguardava o envio das amostras do Brasil para a análise no laboratório do exterior, recebi treinamento para executar tal análise, e para isso trabalhei em projetos em andamento no laboratório no exterior. As amostras, para obtenção dos resultados que deveriam ser apresentados neste item desta sessão desta Tese, foram enviadas ao laboratório no exterior. Consegui processá-las em parte, mas não foi possível concluir a análise das mesmas. Deste modo, a conclusão desta análise só será possível quando de meu retorno ao Brasil, em um eventual pós-doutoramento.

\subsection{Análise da expressão dos receptores mineralocorticoide e glicocorticoide no CPFvm, após o término da sessão de extinção na tarefa de MCC}

Esta análise também foi proposta no projeto inicial que deu origem a esta Tese e também para a FAPESP para obtenção de Bolsa de Estágio de Pesquisa no Exterior (BEPE). No projeto enviado à FAPESP e de conhecimento dos orientadores do Brasil e do Exterior, foi acordado que o ensaio comportamental e a coleta das amostras para 
este ensaio seriam realizados no Brasil e as amostras enviadas ao laboratório no exterior para análise por WB. Realizei o ensaio comportamental, a coleta e o devido processamento das amostras para envio ao laboratório no exterior pouco antes da vigência da BEPE. Contudo, não foi possível realizar a técnica no laboratório no exterior. Portanto, este resultado ainda será obtido quando houver uma oportunidade de continuação deste trabalho. 


\section{DISCUSSÃO}

Os resultados apresentados nesta Tese corroboram com a proposta de que uma única exposição a um evento estressor prévio a um evento traumático pode comprometer a extinção da memória do episódio aversivo (Daskalakis, Lehrner e Yehuda, 2013; Maren, Phan e Liberzon, 2013; Moench e Wellman, 2014; RougemontBücking et al., 2011; Singewald, Schmuckermair, Whittle, Holmes e Ressler, K. J., 2014). Este estudo demonstra que, igualmente como os animais não estressados, o grupo de animais estressado foi capaz de adquirir a memória de extinção ao longo da sessão. Contudo, os animais previamente estressados, apresentaram um aumento na expressão do medo condicionado ao contexto após o treino nesta tarefa. Esta constatação é possível, pois, estatisticamente tanto o grupo previamente estressado e após submetido ao MCC quanto o grupo de animais somente submetidos ao MCC, apresentam diferença significativa quando comparamos os primeiros 5 min com os últimos 5 min de reexposição ao contexto para a sessão de extinção (Figura 1D). Contudo, 24h após a sessão de extinção, quando ambos os grupos foram reexpostos ao contexto aversivo para a sessão de teste da retenção da memória de extinção, o grupo estressado apresentou uma recuperação da memória de extinção significativamente menor do que o grupo não estressado. Isto sugere que o estresse agudo não prejudica a aquisição, mas promove um déficit na consolidação da memória de extinção do medo condicionado contextual. Além disso, o antagonista do receptor para glicocorticoides (Mifeprostone; $10 \mathrm{ng} / \mathrm{lado}$ ) microinjetado nas porções PL ou IL do CPFvm, imediatamente após a sessão de extinção da memória de medo condicionado contextual, atenuou o déficit na consolidação da extinção apresentado pelos animais estressados, sem apresentar efeito sobre os animais não estressados. Contudo, o antagonista de receptores para mineralocorticoides (RU28318, na dose de 150 ng/lado, microinjetado na região IL do CPFvm não mostrou efeito sobre o déficit de extinção promovido pelo estresse agudo. Contudo, ainda será necessário aumentar o número de animais por grupo, e realizar o ensaio comportamental referente a microinjeção do antagonista de receptores para mineralocorticoides na porção PL do CPFvm, bem como testarmos outras doses deste antagonista nas porções PL e IL do CPFvm, para podermos realizar alguma constatação mais assertiva quanto a participação destes receptores no déficit de extinção da memória de MCC observada em nosso protocolo experimental. Deste modo, neste momento, 
ousamos dizer que nossos resultados revelam que uma breve e única exposição a um evento estressor resulta em déficit na consolidação da extinção da memória aversiva contextual, por meio da ativação de receptores para glicocorticoides presentes no CPFvm.

Ao testamos diferentes protocolos experimentais para obter a performance comportamental almejada, para que pudéssemos trabalhar em um protocolo em que fosse possível observar um efeito (deletério ou benéfico) do estresse agudo prévio sobre a performance de extinção da memória de medo, constatamos que a exposição dos animais ao estresse promove aumento na expressão do medo condicionado, e também leva a um déficit na consolidação da extinção do condicionamento aversivo. Uma vez que testamos variações na intensidade do choques nas patas do animais, seu tempo de duração, bem como a sua frequência, os resultados dos diferentes protocolos nos mostram que, o efeito sobre a memória de extinção é variável de acordo com o tempo de exposição ao evento estressor, o intervalo de tempo entre o evento estressor e ao condicionamento aversivo, e a intensidade do estímulo aversivo (ver resultados no APÊNDICE A deste manuscrito), da mesma forma como já observado também em estudos sobre o estresse crônico (Crestani, 2016; Sandi, 2013; Wu e Yan, 2017). Ou ainda podemos dizer que a exposição ao estresse agudo estaria sensibilizando os animais, de modo que, quando submetidos ao paradigma de MCC, desenvolvem o déficit de extinção, o que poderia ser explicado pela "Two-hit Hyphotesis" proposta para alguns transtornos psiquiátricos como esquizofrenia (Davis et al., 2016). Estes achados abrem novas possibilidades de estudo para compreender o que já vem sendo demonstrado na literatura científica, em que diferentes autores tem proposto que uma única exposição ao a estresse pode contribuir para o desenvolvimento do PTSD, em indivíduos susceptíveis (Daskalakis, Lehrner e Yehuda, 2013; Maren, Phan e Liberzon, 2013; Moench e Wellman, 2014; RougemontBücking et al., 2011; Singewald, Schmuckermair, Whittle, Holmes e Ressler, K. J., 2014).

Cada vez mais o estresse se faz presente em nosso cotidiano. Frequentemente nos deparamos com inúmeras situações estressantes que podem provocar respostas emocionais intensas e impactar nossa capacidade cognitiva, como por exemplo fortalecendo o traço mnemônico de memórias de medo ou sua resistência a extinção (Aubry, Serrano e Burghardt, 2016; Quervain, de, Schwabe e Roozendaal, 2017). Compreender os mecanismos pelo qual a extinção de uma memória aversiva ocorre 
e a influência do estresse agudo sobre este processo, pode oferecer a base para o desenvolvimento de técnicas e/ou tratamentos farmacológicos que possam maximizar a terapia de exposição qualidade de vida aos pacientes que sofrem ou possam a vir sofrer com a memórias de medo intrusas que causam instabilidade emocional. Dentro deste contexto, o modelo experimental que nos utilizamos em nossos ensaios farmacológicos e para a coleta das amostras para os ensaios de WB e GolgiStain (protocolo comportamental descrito item 3.14.1. Protocolo 1, da sessão de materiais e métodos desta Tese) apresenta-se como uma excelente ferramenta para o estudo da extinção de memória aversiva em animais de laboratório, com o objetivo de compreender os mecanismos comportamentais e neurobiológicos envolvidos no processo de extinção, tão difundido no comportamento humano e animal, e de tanta importância terapêutica para o tratamento de patologias ocasionadas pelas memórias de medo em humanos (Fitzgerald, Seemann e Maren, 2013; Schiller et al., 2013).

Em nosso ensaio experimental, podemos observar na Figura 1C, que os animais estressados são capazes de aprender a tarefa de condicionamento aversivo, bem como de adquirir a memória de extinção, mesmo apresentando uma hiperexcitação quando reexpostos ao ambiente aversivo (representada pelo aumento da expressão do medo condicionado). Contudo, esses animais apresentam déficit na consolidação da extinção da resposta de medo adquirida. Estes comportamentos se assemelham muito os sintomas observados em pacientes com PTSD, demonstrando a validade de face do modelo. O déficit de extinção observado após a submissão dos animais a um estrese agudo inescapável, torna-se uma importante ferramenta também uma proposta para a investigação do processo de resistência a extinção da memória aversiva que alguns pacientes com PTSD apresentam quando submetidos a terapia de exposição. Esta característica, pouco compreendida, apresentada por muitos pacientes com PTSD, é um desafio aos cientistas que procuram compreender os seus mecanismos para poder desenvolver novas ferramentas que possam contribuir para melhorar a qualidade de vida destes pacientes.

Neste estudo nós avaliamos os possíveis efeitos da administração do antagonista de receptores para glicocorticoides Mifepristone, na porção IL ou PL do CPFvm, sobre o processo de consolidação da extinção de memória aversiva (Protocolo 2). E constatamos que os receptores para glicocorticoides em ambas as porções do CPFvm participam do estabelecimento do déficit na consolidação da extinção da memória de medo em animais estressados, uma vez que o antagonismo 
destes receptores reverte o déficit ocasionado pelo estresse (Figuras $2 \mathrm{C}$ e $3 \mathrm{C}$ ). Já a administração do antagonista para receptores mineralocorticoides, Oxprenoato, na dose geralmente empregada em estudos comportamentais encontrada na literatura, imediatamente após a sessão de extinção não foi capaz de reverter o déficit da consolidação da extinção da memória aversiva quando administrado na porção IL do CPFvm (Figura 4C). E como mencionado anteriormente, podemos concluir que o déficit de extinção promovido por efeitos sustentados do estresse agudo prévio ao MCC depende da ativação de receptores glicocorticoides no CPFvm. A diferença observada entre a administração dos antagonistas mineralocorticoides e glicocorticoides podem ser explicadas pelos mecanismos genômicos e não genômicos e expressão destes receptores. É possível que o estresse agudo prévio, mediante elevação dos níveis de corticosterona, promova efeitos não genômicos e genômicos, sendo este último responsável pela síntese de proteínas que podem estar envolvidas nos efeitos deletérios sustentados do estresse. O mesmo não ocorreria no caso dos receptores mineralocorticoides, que promoveriam efeitos não-genômicos, em que ações rápidas promovidas diante deste mecanismo não permitem observar efeitos sustentados do estresse agudo. Um ensaio interessante neste caso poderia ser testar um time-course, realizando o MCC e a administração do antagonista para receptores mineralocorticoides em diferentes momentos após o estresse por restrição. Neste caso, podendo ser observando melhor os efeitos deste quando em um momento mais próximo ao ER. Ainda podemos citar o possível impacto do estresse agudo na expressão dos receptores mineralocorticoides e glicocorticoides na morfologia dendrítica de neurônios piramidais das camadas II e III do CPFvm. Assim, seguindo alguns estudos clínicos post-mortem que verificaram a diminuição do RNA mensageiro para receptores mineralocorticoides no cérebro de pacientes diagnosticados com esquizofrenia e transtorno bipolar, e que o estresse é capaz de promover alterações na expressão destes receptores no CPF, poderíamos estar diante do caso de haver um quadro de diminuição na expressão dos receptores mineralocorticoides em nosso modelo (Haarst, van, Oitzl e Kloet, de, 1997; Han, Ding e Shi, 2014; Kloet, de, 2000, 2014; Klok et al., 2011; Kolber, Wieczorek e Muglia, 2008; Qi et al., 2013; Xing et al., 2004). Porém, esta explicação torna-se especulativa, uma vez que não obtivemos os resultados oriundos dos ensaios de WB e GolgiStain para que fosse possível explicarmos de forma mais assertiva os resultados comportamentais e farmacológicos e testarmos a hipótese deste estudo. Estes 
resultados seriam importantes para compreendermos um pouco sobre os mecanismos neurais que envolvem o déficit de extinção que muitos pacientes com PTSD apresentam.

As memórias são influenciadas pelas emoções (McGaugh, 2015; Mueller e Cahill, 2010) de modo que, quanto maior o impacto emocional no momento do armazenamento de uma memória, esta será lembrada mais facilmente e com maior riqueza de detalhes (Mueller and Cahill 2010; Izquierdo et al. 2016; LaLumiere et al. 2017). Condições de estresse e medo contribuem para o fortalecimento e persistência de uma memória. E o estresse, juntamente com o sentimento de medo coloca o indivíduo em um estado de alerta em nível psicológico e fisiológico (Izquierdo, Furini e Myskiw, 2016; Johansen et al., 2011), permitindo que tenhamos uma reação adequada frente a situações que apresentem perigo a nossa integridade. Contudo, a evocação extremamente detalhada e em momentos inapropriados de memórias de medo, pode resultar transtornos emocionais, que muitas vezes estão associados ao déficit de extinção da memória de medo (Izquierdo, Furini e Myskiw, 2016; Morrison e Ressler, 2014; Quirk, 2017). Em nossos resultados observamos que ambos os grupos, estressados e não estressados, aprendem/adquirem a memória de medo condicionado de maneira que não há diferença entre os grupos. Ambos são capazes de aprender. E apesar do aumento na expressão desta memória 24h depois, ambos os grupos apresentaram a habilidade de extinguir a reposta perante o estímulo aversivo (ambiente/contexto). E por isso, apesar de haver um aumento na expressão do medo condicionado, não estamos observando um fenômeno de fortalecimento do traço mnemônico original, ou super consolidação da memória de medo, ao ponto de não observarmos o aprendizado da extinção, mas sim, um prejuízo na consolidação da extinção, uma inabilidade de evocar a o aprendizado da extinção.

O cortisol, hormônio glicocorticoide em humanos, e a corticosterona, hormônio glicocorticoide em roedores (Myers, McKlveen e Herman, 2014), após liberados na circulação sistêmica, atravessam a barreira hematoencefálica, e exercem seus efeitos biológicos ao se ligarem aos receptores do tipo mineralocorticoide, em condições basais, e receptores glicocorticoide, durante o pico do ciclo circadiano deste hormônio, ou em condições de estresse (Kolber, Wieczorek e Muglia, 2008; Myers, McKlveen e Herman, 2014; Roesler e Schröder, 2011; Solomon et al., 2014). Estudos clínicos sugerem que perfil de extinção é alterado mediante a exposição do sujeito em períodos distintos do dia, podendo sofrer influência dos níveis circulantes de 
corticosterona, ou seja, do "relógio" biológico (Kinner et al., 2016; Merz et al., 2013, 2014; Meuret et al., 2016). Nós avaliamos os níveis de corticosterona nos roedores imediatamente após o estresse (no caso do grupo de animais estressados) e em diferentes tempos após o protocolo de extinção do medo condicionado contextual (em ambos os grupos, estressados e não estressados). Esperamos poder apresentar e discutir estes resultados quando da apresentação dos resultados desta Tese em cerimônia de defesa da mesma. Ainda, considerando a possível influência da corticosterona endógena, em nosso ensaio experimental constatamos que a extinção realizada no período vespertino, onde há liberação da corticosterona em roedores resulta em déficit na consolidação da extinção da memória de medo contextual não somente nos animais estressados, mas também nos animais não estressados. Isto pode indicar que o aprendizado da extinção é estado dependente dos níveis de corticosterona endógena. Devido à importância deste achado, mais ensaios precisam ser realizados para que os mecanismos pelo qual este fenômeno foi observado possa ser elucidado. É isso será uma nova abordagem deste estudo, que originou esta Tese.

A liberação do cortisol/corticosterona e sua interação com receptores glicocorticoides e mineralocorticoides em diferentes regiões encefálicas é crítica para a regulação do eixo Hipófise-pituitária-adrenal (HPA), controle das respostas emocionais e performance cognitiva (Klok et al., 2011). A sinalização mediata pelos receptores para glicocorticoides ocorre por dois mecanismos básicos: interação com o genoma e interação com as membranas. Estudos também demostram que a ação de hormônios glicocorticoides segue uma curva em "U" invertido, sendo dependente das suas concentrações circulantes e da ocupação de receptores glicocorticoides e mineralocorticoides (Izquierdo, Furini e Myskiw, 2016; Kolber, Wieczorek e Muglia, 2008; Lass-Hennemann e Michael, 2014; McKlveen et al., 2013; Popoli et al., 2012; Sapolsky, 2015). Portanto o efeito que estamos observando pode ser decorrente de uma alteração na expressão destes receptores para hormônios glicocorticoides, e/ou, devido ao impacto das concentrações de hormônios do estresse circulantes influenciando a performance cognitiva dos animas. Neste último caso, animais estressados por estarem sensibilizados à estímulos, quando expostos a tarefa aversiva de MCC, apresentariam um aumento rápido de hormônios glicocorticoides, que pode aumentar a expressão da resposta emocional condicionada associada a memória aversiva, porém, ao longo da sessão de extinção, a presença deste hormônio circulante e em crescente aumento pode comprometer a consolidação da memória de 
extinção. Contudo, seria necessária a condução da análise por WB bem como a tabulação dos dados referentes ao ensaio de ELISA para a análise dos níveis de corticosterona, antes da defesa desta Tese para confirmarmos ou não estas especulações.

Como seguimento deste estudo, para elucidação dos mecanismos pelos quais o estresse exerça efeitos sustentados sobre a extinção do MCC, nós realizaremos os ensaios de WB, juntamente com o ensaio de reação em cadeia da polimerase em tempo real (RT-PCR) para avaliarmos também os níveis de RNA mensageiro para os receptores alvo deste estudo. Para isso, foram coletadas amostras de tecido cerebral da região do CPFvm dos animais expostos ao nosso protocolo experimental 5, que foram processadas e armazenadas adequadamente, para a análise por meio de ensaios de WB e PCR, bem como está em curso o estudo de morfologia dendrítica desta estrutura encefálica (Protocolo 6).

Devido a situação em que ocorrerá a defesa desta Tese, já explicada aos Professores membros da comissão examinadora, e detalhada via descrição nos anexos deste manuscrito, e ainda, por haver dados a serem tabulados (revisando inclusive a análise estatística de todo o estudo para futura publicação em periódico), e experimentos a serem executados para testar a hipótese deste estudo, a discussão desta Tese está escrita de forma preliminar. 


\section{CONCLUSÃO}

Os resultados apresentados nesta Tese permitem concluir que:

- O estresse agudo promove um aumento na expressão do medo condicionado;

- O estresse agudo não interfere no processo de aquisição da memória de extinção, porém, de forma interessante é capaz de promover déficit na consolidação da memória de extinção;

- Os receptores para glicocorticoides presentes na região IL e PL do CPFvm parecem modular o processo de consolidação da extinção de memória aversiva, em casos de exposição ao estresse, uma vez que a administração de um antagonista para tais receptores (Mifepristone 10ng por hemisfério cerebral) nestas estruturas encefálica, separadamente, imediatamente após a sessão de extinção parece ser capaz de reverter o déficit de extinção promovido pelo estresse agudo prévio ao condicionamento.

- A extinção realizada no período vespertino, onde há liberação da corticosterona endógena em roedores, resulta em déficit na consolidação da extinção da memória de medo contextual não somente nos animais estressados, mas também nos animais não estressados. Isto pode indicar que o aprendizado da extinção é estado dependente dos níveis de corticosterona endógena. Devido à importância deste achado, mais ensaios precisam ser realizados para elucidar este possível fenômeno. 


\section{CONSIDERAÇÕES FINAIS}

Algumas dificuldades para o desenvolvimento deste estudo ocorreram. Nossas maiores dificuldades foram para padronizar o procedimento comportamental, e, para garantir a aferição das respostas autonômicas dos animais estressados ou não durante o protocolo de MCC, como parte dos objetivos a serem alcançados no desenvolvimento desta Tese. Inicialmente, a aferição da pressão arterial média e frequência cardíaca, foi proposta e a inserção de uma sonda radio telemétrica na aorta abdominal do animal foi a metodologia escolhida. Esta é uma proposta interessante, visto que esta sonda permanece no abdômen do animal, não há partes exteriorizadas da mesma, e não há o risco de perda do animal por perda do registro do sinal (por entupimento com sangue coagulado no cateter de polietileno, por exemplo), permitindo a análise em todos os dias do protocolo de MCC (condicionamento, extinção e teste). Em nosso laboratório já havia algumas sondas para utilizarmos. Ainda nos primeiros meses de execução deste projeto, treinamos as primeiras cirurgias para inserção da sonda no animal, obtivemos êxito, e nos pareceu bastante promissor o procedimento. Contudo, as sondas precisaram ir à assistência técnica pelo fato de não estarem emitindo o sinal adequado para ser captado pelo equipamento rádio receptor (responsável por captar o sinal gerado pela sonda e os enviar em forma de dados a um sistema computadorizado). Também, alguns projetos que foram enviados na época, para aquisição de auxílio financeiro para a compra de novas sondas radio telemétricas para o nosso laboratório, não foram aprovados.

Considerando o momento corrente de nosso cenário econômico, o custo elevado para aquisição de novas sondas, e que as sondas já adquiridas precisaram de reparos, cujo tempo para retornarem ao nosso laboratório não estava previsto para logo, ficou impraticável esta metodologia. Desta forma fomos em busca de alternativas para conseguir registrar a resposta autonômica dos animais. Foi então que conseguimos o contato do técnico Carlos Alberto Aguiar da Silva, que trabalha do Departamento de Fisiologia da Faculdade de Medicina da USP-Ribeirão Preto. Com o auxílio dele foi possível aprender o procedimento para inserção de um cateter de polietileno na aorta abdominal do animal, a fim de realizar o registro autonômico. Esta técnica estava sendo utilizada para aferição de repostas cardiovasculares em procedimentos experimentais rápidos, de curto prazo, mas não havia sido utilizada em ensaios comportamentais, com uma duração considerável como o nosso, e foram 
necessárias algumas adaptações. Foi então que iniciamos a padronização de um processo cirúrgico para inserção um cateter de polietileno na aorta abdominal, seguido da sua exteriorização no dorso do animal para que pudesse ser conectado com outro cateter ligado a um sistema de que permite o registro das respostas autonômicas. Além disso esta técnica foi uma alternativa que encontramos para a coleta de amostras de sangue (através do cateter exteriorizado no dorso do animal) após o término dos ensaios comportamentais (nos diferentes tempos já pré-determinados em nosso estudo) reduzindo o número de animais a ser utilizado no estudo para esta finalidade, visto que em nossa proposta inicial em nosso projeto, para a coleta de amostras de sangue, iríamos realizar a decapitação de grupos de animais, em diferentes tempos após cada sessão do MCC. Foram alguns meses de padronização da técnica cirurgia e quando finalmente estava consolidada a técnica (conforme descrita em materiais e métodos deste relatório), iniciamos os primeiros ensaios aferindo as respostas comportamentais associadas a resposta autonômica.

Conforme descrito na sessão de resultados desta Tese, nós avaliamos quais seriam as consequências da exposição de animais a uma única sessão de estresse por restrição, sobre o perfil de extinção da memória de medo condicionado ao contexto. Demonstramos que o estresse agudo promove um aumento na expressão da memória de medo condicionado ao contexto, sem comprometer o processo de aquisição da memória de extinção Contudo, o estresse promove déficit na consolidação da memória de extinção, sendo este efeito variável de acordo com o tempo de exposição ao evento estressor, o intervalo entre o evento estressor e o MCC, e a intensidade do estímulo aversivo (choque nas patas). Dentre os protocolos comportamentais testados, optamos seguir a condução dos experimentos, executando o protocolo abaixo (descrito item 3.14.1. Protocolo 1 , da sessão de materiais e métodos desta tese): 


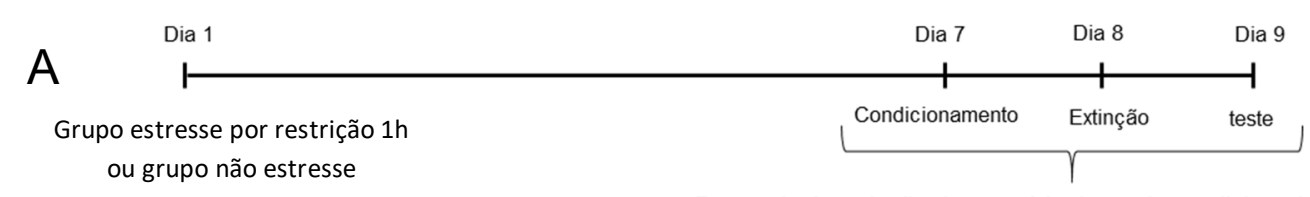

Protocolo de extinção da memória de medo condicionada ao contexto

B

\begin{tabular}{|c|c|c|c|c|}
\hline $\begin{array}{l}\text { Condicionamento } \\
\text { (Habitução }(10 \mathrm{~min}) 2 \mathrm{~h} \rightarrow \text { treino })\end{array}$ & $24 \mathrm{~h}$ & $\begin{array}{l}\text { Extinção } \\
\text { (30 min) }\end{array}$ & $24 \mathrm{~h}$ & $\begin{array}{c}\text { Teste } \\
\text { (10 min) }\end{array}$ \\
\hline
\end{tabular}

Treino: 270 s de habituação; 4 choques nas patas ( $0.85 \mathrm{~mA} / 1$ s; randomizados); $2 \mathrm{~min}$ sem choques.

Figura 6. Perfil de extinção da memória de medo condicionado em animais estressados e não estressados (estudo piloto). (A). Representação esquemática do intervalo de tempo entre os procedimentos comportamentais. (B). Representação esquemática do protocolo de extinção da memória de condicionamento aversivo.

Na realização do ensaio piloto descrito na figura 11 no APÊNCIE A desta Tese, os animais foram mantidos agrupados em número de 4 animais por caixa moradia. Porém, a partir do momento em que realizássemos a cirurgia de canulação da aorta abdominal dos animais, para aferição das respostas autonômicas de PAM e FC, seria necessário manter apenas 1 animal por caixa moradia, pois, o cateter inserido no lúmen do vaso e exteriorizado no dorso do animal, poderia ser roído por outros animais presentes na caixa moradia. Foi realizado um ensaio piloto com os animais mantidos em regime de isolamento, e o perfil comportamental não foi alterado (Figura 11C APÊNDICE A). Feito isso, e testadas diferentes metodologias para viabilidade da cirurgia, realizando-a em diferentes momentos do ensaio comportamental, o protocolo experimental foi padronizado, conforme demostrado na figura 7 , e partimos para os objetivos seguintes do estudo.

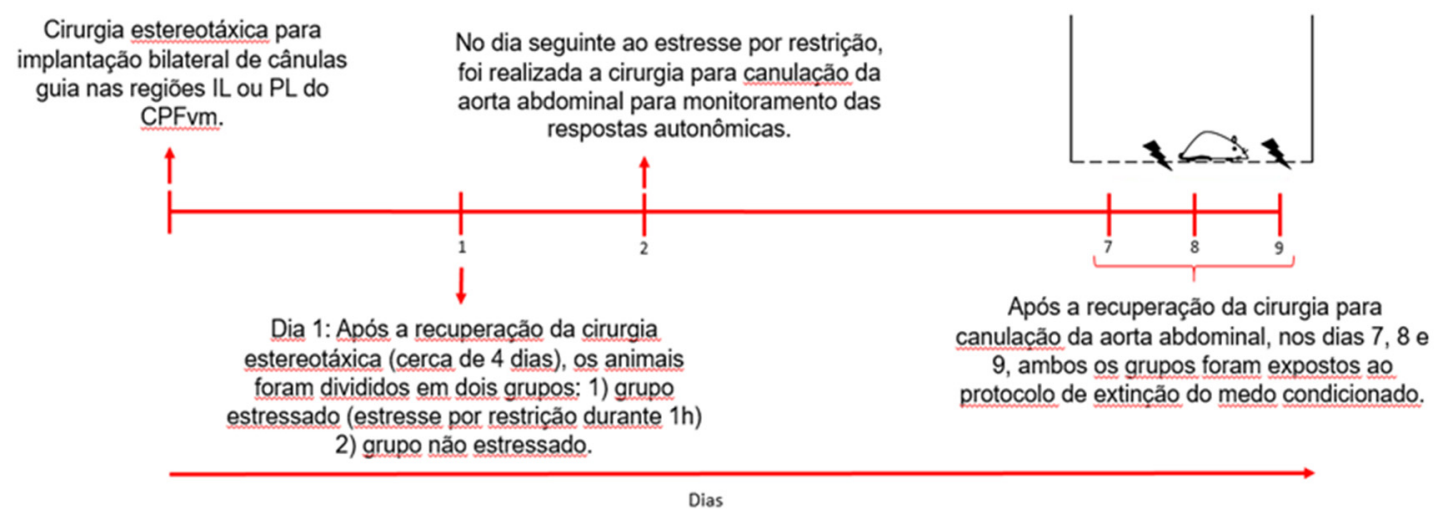

Figura 7. Protocolo experimental para aferição das respostas comportamentais e autonômicas. 
Inicialmente tentamos realizar o registro da PAM e da FC a partir da sessão de condicionamento. Contudo, não foi possível. Pelo fato de o cateter ser exteriorizado, quando o animal recebia o estímulo elétrico nas patas, ao se movimentar de forma brusca na caixa ocasionava a torção do cateter e ausência de registro. Optamos, desta forma, por aferir as respostas autonômicas unicamente nas sessões de extinção e teste da retenção da memória de extinção.

Conduzimos os experimentos seguintes, aferindo as respostas autonômicas durante as sessões de extinção e de teste, avaliando a participação dos receptores para glicocorticoides presentes na porção IL do CPFvm na consolidação da memória aversiva, inicialmente. Também conduzimos as primeiras coletas de amostras de sangue através do cateter inserido na aorta abdominal do animal, em diferentes tempos após cada sessão do MCC, para posterior análise dos níveis de corticosterona. Por trabalharmos com um fator limitante importante, no que se refere ao tempo para condução dos experimentos, que fica restrito ao período matutino, evitando o período vespertino onde há elevação dos níveis de corticosterona em roedores, o número de animais por experimento também era limitado. Dentro destas considerações, executamos os experimentos de modo que tivéssemos 2 animais de cada grupo ao mínimo em cada ensaio experimental, até completarmos um número de animais por grupo suficiente para aplicarmos os testes estatísticos. Os grupos de animais, estressados e não estressados foram separados, deste a sessão de condicionamento, em outros dois grupos: grupos que viriam a receber a administração de antagonista, e grupos que viriam a receber o veículo, ambos a serem administrados imediatamente após a sessão de extinção. Quando juntamos os dados dos experimentos realizados, a análise estatística se mostrou inconclusiva, de modo que estes resultados não foram apresentados nesta Tese. Infelizmente estes grupos de animais apresentaram diferenças no comportamento e nas respostas autonômicas antes de receberem o tratamento, de modo que não podemos atribuir a resposta final observada ao tratamento ou condição. E, devido ao não aproveitamento destes resultados experimentais, foram realizadas novas coletas de amostras de sangue dos animais, oriundas de resultados de experimentos válidos.

Desta maneira decidimos por conduzir os ensaios comportamentais sem o registro da atividade autonômica, para conseguirmos compor um conjunto de resultados comportamentais passível de discussão, bem como a execução das análises pelos ensaios bioquímicos e de morfologia propostos em nosso projeto para 
testar nossa hipótese. E considerando as dificuldades encontradas no desenvolvimento inicial deste projeto, e para avançar em nossos objetivos, resolvemos ajustar o ensaio comportamental de MCC, de modo que pudéssemos trabalhar com um maior número de animais por experimento, melhorando nosso aproveitamento de tempo, visto que as tarefas comportamentais só são realizadas durante o período matutino. A sessão de extinção de 30 min era nosso fator mais limitante, então, consultando a literatura científica, decidimos reduzir o tempo de extinção para 20 min, modificando ou não a aversividade do protocolo de condicionamento (alterando ou não o número e o tempo da emissão de estímulos elétricos nas patas dos animais durante a sessão de condicionamento). Em suma, padronizamos o protocolo descrito na figura abaixo:

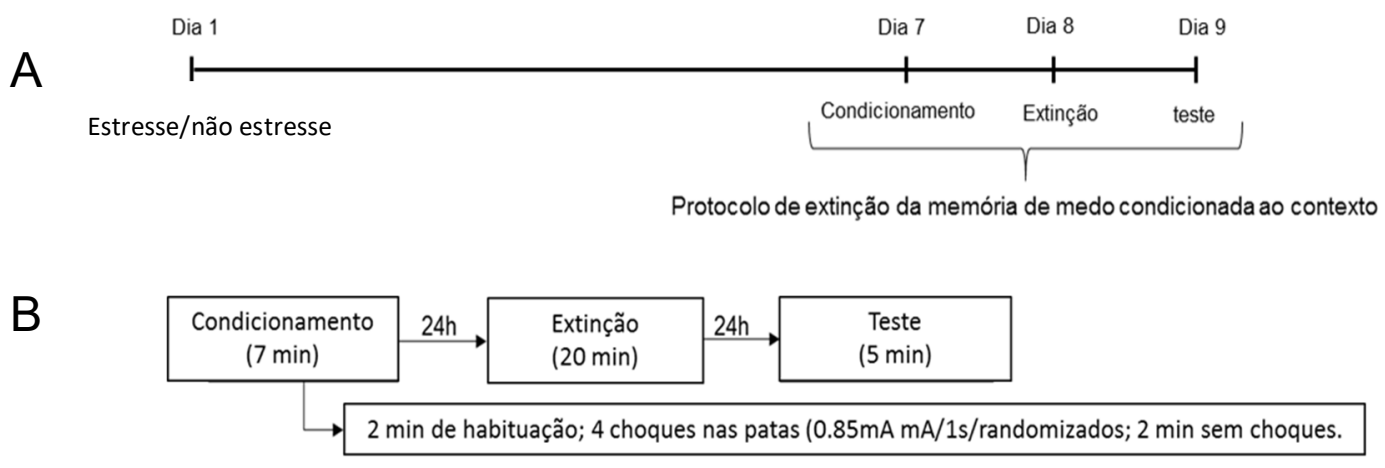

Figura 8. Perfil de extinção da memória de medo condicionado ao contexto e da retenção da memória de extinção em animais estressados e não estressados submetidos ao protocolo experimental 1 (descrito no item 3.14.1, materiais e métodos). (A). Representação esquemática do intervalo de tempo entre os procedimentos comportamentais. (B). Representação esquemática do protocolo de extinção da memória de condicionamento aversivo.

A partir da padronização deste protocolo mais enxuto, nós avançamos em nossos objetivos, e mostramos que a administração bilateral do antagonista de receptores para glicocorticoides Mifepristone (ou RU486) na dose 10ng/lado, microinjetado na porção IL ou PL do CPFvm, parece reverter o déficit na consolidação da memória de extinção promovido pelo estresse agudo, sem causar efeito sobre a consolidação da memória de extinção em animais não estressados. Novas coletas de amostras de sangue e tecido para os ensaios de biologia molecular foram realizadas a partir deste ensaio comportamental. 
É preciso ponderar as dificuldades técnicas iniciais para padronizarmos o procedimento comportamental, a coleta das amostras de sangue, e para o registro da resposta cardiovascular (que era parte dos objetivos iniciais desta Tese, mas foi descartada, mediante a impossibilidade de execução). Foi necessário o estudo de alternativas para a condução de nossas análises, acarretando em novas padronizações e com isso surgiu a necessidade de alterar o protocolo experimental, depois de já estar considerado padronizado. Porém, sanadas as dificuldades iniciais, conduzimos nossos objetivos dentro de nossas possibilidades.

O tempo transcorrido para a padronização dos procedimentos a serem empregados no estudo, as dificuldades de ordem técnica e estrutural, bem como de inúmeras intercorrências ao longo destes anos, inclusive no que diz respeito a qualidade dos animais fornecidos pelo Biotério Central USP Ribeirão Preto, impactaram no curso lento para o desenvolvimento deste estudo. Deste modo, tendo em vista os interessantes resultados obtidos, o estudo que resulta nesta Tese não terminará quando da defesa deste doutorado. Novas análises e experimentos estão sendo pensados de modo que permitam a elucidação mais concreta dos resultados obtidos nos aspectos comportamental e farmacológico desta pesquisa. 


\section{REFERÊNCIAS BIBLIOGRÁFICAS}

ABRAMOWITZ, J. S. The practice of exposure therapy: relevance of cognitivebehavioral theory and extinction theory. Behavior therapy, v. 44, n. 4, p. 548-558, dez. 2013.

ACHARJEE, S.; NAYANI, N.; TSUTSUI, M.; HILL, M. N.; OUSMAN, S. S.; PITTMAN, Q. J. Altered cognitive-emotional behavior in early experimental autoimmune encephalitis--cytokine and hormonal correlates. Brain, Behavior, and Immunity, v. 33, p. 164-172, out. 2013.

AKIRAV, I.; MAROUN, M. Stress modulation of reconsolidation. Psychopharmacology, v. 226, n. 4, p. 747-761, 6 out. 2012.

ALBERINI, C. M.; LEDOUX, J. E. Memory reconsolidation. Current Biology, v. 23, n. 17, p. R746-R750, set. 2013.

AMERICAN PSYCHIATRIC ASSOCIATION. Posttraumatic stress disorder (PTSD). Disponível em: <http://www.psychiatry.org/mental-health/ptsd>. Acesso em: 6 fev. 2018.

ARAUJO, H. F.; KAPLAN, J.; DAMASIO, H.; DAMASIO, A. Involvement of cortical midline structures in the processing of autobiographical information. PeerJ, v. 2, p. e481, 22 jul. 2014.

ASOK, A.; KANDEL, E. R.; RAYMAN, J. B. The Neurobiology of Fear Generalization. Frontiers in Behavioral Neuroscience, v. 12, p. 329, 2018.

ASUKAI, N. [Treatment of posttraumatic stress disorder and extinction learning of traumatic memory]. Nihon Shinkei Seishin Yakurigaku Zasshi = Japanese Journal of Psychopharmacology, v. 33, n. 3, p. 111-115, jun. 2013.

ATSAK, P.; HAUER, D.; CAMPOLONGO, P.; SCHELLING, G.; FORNARI, R. V.; ROOZENDAAL, B. Endocannabinoid Signaling within the Basolateral Amygdala Integrates Multiple Stress Hormone Effects on Memory Consolidation. Neuropsychopharmacology: Official Publication of the American College of Neuropsychopharmacology, 30 dez. 2014.

ATSAK, P.; HAUER, D.; CAMPOLONGO, P.; SCHELLING, G.; MCGAUGH, J. L.; ROOZENDAAL, B. Glucocorticoids interact with the hippocampal endocannabinoid system in impairing retrieval of contextual fear memory. Proceedings of the National 
Academy of Sciences of the United States of America, v. 109, n. 9, p. 3504-3509, 28 fev. 2012.

AUBRY, A. V.; SERRANO, P. A.; BURGHARDT, N. S. Molecular Mechanisms of Stress-Induced Increases in Fear Memory Consolidation within the Amygdala. Frontiers in Behavioral Neuroscience, v. 10, 21 out. 2016.

BADDELEY, A. Working Memory: Theories, Models, and Controversies. Annual Review of Psychology, v. 63, n. 1, p. 1-29, 10 jan. 2012.

BARROS, D. M.; PEREIRA, P.; MEDINA, J. H.; IZQUIERDO, I. Modulation of working memory and of long- but not short-term memory by cholinergic mechanisms in the basolateral amygdala. Behavioural Pharmacology, v. 13, n. 2, p. 163-167, mar. 2002.

BEAR, M. F. Neurociencias: desvendando o sistema nervoso. Porto Alegre: Artmed, 2002.

BENETTI, F.; SILVEIRA, C. K. B. DA; ROSA, J.; IZQUIERDO, I. Histamine acting on the basolateral amygdala reverts the impairment of aversive memory of rats submitted to neonatal maternal deprivation. Behavioural Brain Research, v. 278C, p. 83-89, 22 set. 2014.

BENTZ, D.; MICHAEL, T.; WILHELM, F. H.; HARTMANN, F. R.; KUNZ, S.; ROHR, I. R. R. VON; QUERVAIN, D. J.-F. DE. Influence of stress on fear memory processes in an aversive differential conditioning paradigm in humans. Psychoneuroendocrinology, v. 38, n. 7, p. 1186-1197, jul. 2013.

BERLAU, D.; MCGAUGH, J. Enhancement of extinction memory consolidation: The role of the noradrenergic and GABAergic systems within the basolateral amygdala. Neurobiology of Learning and Memory, v. 86, n. 2, p. 123-132, set. 2006.

BERMÚDEZ-RATTONI, F.; MCGAUGH, J. L. Memory reconsolidation and memory updating: Two sides of the same coin? Neurobiology of Learning and Memory, v. 142, p. 1-3, jul. 2017.

BOLLES, R. C.; COLLIER, A. C. The effect of predictive cues on freezing in rats. Animal Learning \& Behavior, v. 4, n. 1, p. 6-8, mar. 1976.

BORGHANS, B. Animal models for posttraumatic stress disorder: An overview of what is used in research. World Journal of Psychiatry, v. 5, n. 4, p. 387, 2015. 
BRAND, N.; HANSON, E.; GODAERT, G. Chronic Stress Affects Blood Pressure and Speed of Short-Term Memory. Perceptual and Motor Skills, v. 91, n. 1, p. 291-298, ago. 2000.

BREMNER, J. D. Traumatic stress: effects on the brain. Dialogues in clinical neuroscience, v. 8, n. 4, p. 445-461, 2006.

BREWIN, C. R.; HOLMES, E. A. Psychological theories of posttraumatic stress disorder. Clinical Psychology Review, v. 23, n. 3, p. 339-376, maio 2003.

BURIANOVA, H.; MCINTOSH, A. R.; GRADY, C. L. A common functional brain network for autobiographical, episodic, and semantic memory retrieval. Neurolmage, v. 49 , n. 1, p. 865-874, jan. 2010.

CAHILL, L.; MCGAUGH, J. L. Modulation of memory storage. Current opinion in neurobiology, v. 6, n. 2, p. 237-242, abr. 1996.

CALLEGARI-JACQUES, S. Bioestatística princípios e aplicações. Porto Alegre: Artmed, 2007.

CAMPOS, A. C.; FOGACA, M. V.; AGUIAR, D. C.; GUIMARAES, F. S. Animal models of anxiety disorders and stress. Revista Brasileira de Psiquiatria, v. 35, n. suppl 2, p. S101-S111, 2013.

CARVALHO MYSKIW, J. DE; BENETTI, F.; IZQUIERDO, I. Behavioral tagging of extinction learning. Proceedings of the National Academy of Sciences, v. 110, n. 3, p. 1071-1076, 31 dez. 2012.

CHEN, G.; ZOU, X.; WATANABE, H.; DEURSEN, J. M. VAN; SHEN, J. CREB Binding Protein Is Required for Both Short-Term and Long-Term Memory Formation. Journal of Neuroscience, v. 30, n. 39, p. 13066-13077, 29 set. 2010.

CLAY, R.; HEBERT, M.; GILL, G.; STAPLETON, L. A.; PRIDHAM, A.; COADY, M.; BISHOP, J.; ADAMEC, R. E.; BLUNDELL, J. J. Glucocorticoids are required for extinction of predator stress-induced hyperarousal. Neurobiology of learning and memory, v. 96, n. 2, p. 367-377, set. 2011.

CONWAY, M. A. Episodic memories. Neuropsychologia, v. 47, n. 11, p. 2305-2313, set. 2009. 
CORDERO, M. I.; VENERO, C.; KRUYT, N. D.; SANDI, C. Prior exposure to a single stress session facilitates subsequent contextual fear conditioning in rats. Hormones and Behavior, v. 44, n. 4, p. 338-345, nov. 2003.

CRESTANI, C. C. Emotional Stress and Cardiovascular Complications in Animal Models: A Review of the Influence of Stress Type. Frontiers in Physiology, v. 7, 24 jun. 2016.

DASKALAKIS, N. P.; LEHRNER, A.; YEHUDA, R. Endocrine aspects of post-traumatic stress disorder and implications for diagnosis and treatment. Endocrinology and Metabolism Clinics of North America, v. 42, n. 3, p. 503-513, set. 2013.

DAVIS, J. et al. A review of vulnerability and risks for schizophrenia: Beyond the two hit hypothesis. Neuroscience and Biobehavioral Reviews, v. 65, p. 185-194, jun. 2016.

DE LA CRUZ, V.; RODRIGUEZ-ORTIZ, C. J.; BALDERAS, I.; BERMUDEZ-RATTONI, $F$. Medial temporal lobe structures participate differentially in consolidation of safe and aversive taste memories. European Journal of Neuroscience, v. 28, n. 7, p. 13771381, out. 2008.

DICKERSON, B. C.; EICHENBAUM, H. The Episodic Memory System: Neurocircuitry and Disorders. Neuropsychopharmacology, v. 35, n. 1, p. 86-104, 23 set. 2009.

DOMINGOS, L. B.; HOTT, S. C.; TERZIAN, A. L. B.; RESSTEL, L. B. M. P2X7 purinergic receptors participate in the expression and extinction processes of contextual fear conditioning memory in mice. Neuropharmacology, ago. 2017.

FARIA-SILVA, R.; DUARTE, F. V.; SANTOS, R. A. S. Short-term angiotensin(1-7) receptor MAS stimulation improves endothelial function in normotensive rats. Hypertension, v. 46, n. 4, p. 948-952, out. 2005.

FASSINI, A.; ANTERO, L. S.; CORREAA, F. M. A.; JOCA, S. R.; RESSTEL, L. B. M. The prelimbic cortex muscarinic M3 receptor-nitric oxide-guanylyl cyclase pathway modulates cardiovascular responses in rats. Journal of Neuroscience Research, 16 jan. 2015.

FERREIRA-JUNIOR, N. C.; FEDOCE, A. G.; ALVES, F. H. F.; RESSTEL, L. B. M. Medial prefrontal cortex N-methyl-D-aspartate receptor/nitric oxide/cyclic guanosine monophosphate pathway modulates both tachycardic and bradycardic baroreflex responses. Journal of Neuroscience Research, v. 91, n. 10, p. 1338-1348, out. 2013. 
FIORENZA, N. G.; ROSA, J.; IZQUIERDO, I.; MYSKIW, J. C. Modulation of the extinction of two different fear-motivated tasks in three distinct brain areas. Behavioural Brain Research, v. 232, n. 1, p. 210-216, jun. 2012.

FITZGERALD, P. J.; SEEMANN, J. R.; MAREN, S. Can fear extinction be enhanced? A review of pharmacological and behavioral findings. Brain Research Bulletin, v. 105, p. 46-60, dez. 2013.

FUKUSHIMA, H.; ZHANG, Y.; ARCHBOLD, G.; ISHIKAWA, R.; NADER, K.; KIDA, S. Enhancement of fear memory by retrieval through reconsolidation. eLife, v. 3, p. e02736, 2014.

FURINI, C. R. G.; MYSKIW, J. C.; BENETTI, F.; IZQUIERDO, I. New frontiers in the study of memory mechanisms. Revista Brasileira de Psiquiatria, v. 35, n. 2, p. 173177, abr. 2013.

GANON-ELAZAR, E.; AKIRAV, I. Cannabinoids and traumatic stress modulation of contextual fear extinction and GR expression in the amygdala-hippocampal-prefrontal circuit. Psychoneuroendocrinology, v. 38, n. 9, p. 1675-1687, set. 2013.

GARELICK, M. G.; STORM, D. R. The relationship between memory retrieval and memory extinction. Proceedings of the National Academy of Sciences, v. 102, n. 26, p. 9091-9092, 28 jun. 2005.

GEORGE, S. A.; RODRIGUEZ-SANTIAGO, M.; RILEY, J.; RODRIGUEZ, E.; LIBERZON, I. The effect of chronic phenytoin administration on single prolonged stress induced extinction retention deficits and glucocorticoid upregulation in the rat medial prefrontal cortex. Psychopharmacology, v. 232, n. 1, p. 47-56, jan. 2015.

GHOSAL, S.; BUNDZIKOVA-OSACKA, J.; DOLGAS, C. M.; MYERS, B.; HERMAN, J. $P$. Glucocorticoid receptors in the nucleus of the solitary tract (NTS) decrease endocrine and behavioral stress responses. Psychoneuroendocrinology, v. 45, p. 142-153, jul. 2014.

GIBB, R.; KOLB, B. A method for vibratome sectioning of Golgi-Cox stained whole rat brain. Journal of Neuroscience Methods, v. 79, n. 1, p. 1-4, jan. 1998.

GIESE, K. P.; MIZUNO, K. The roles of protein kinases in learning and memory. Learning \& Memory (Cold Spring Harbor, N.Y.), v. 20, n. 10, p. 540-552, 16 set. 2013. 
GOURLEY, S. L.; KEDVES, A. T.; OLAUSSON, P.; TAYLOR, J. R. A history of corticosterone exposure regulates fear extinction and cortical NR2B, GluR2/3, and BDNF. Neuropsychopharmacology: Official Publication of the American College of Neuropsychopharmacology, v. 34, n. 3, p. 707-716, fev. 2009.

GRANJEIRO, E. M.; SCOPINHO, A. A.; CORREAA, F. M. A.; RESSTEL, L. B. M. Prelimbic but not infralimbic cortex is involved in the pressor response to chemoreflex activation in awake rats. Experimental Physiology, v. 96, n. 5, p. 518-527, maio 2011.

HAARST, A. D. VAN; OITZL, M. S.; KLOET, E. R. DE. Facilitation of feedback inhibition through blockade of glucocorticoid receptors in the hippocampus. Neurochemical Research, v. 22, n. 11, p. 1323-1328, nov. 1997.

HAN, F.; DING, J.; SHI, Y. Expression of amygdala mineralocorticoid receptor and glucocorticoid receptor in the single-prolonged stress rats. BMC neuroscience, v. 15, p. 77, 2014.

HICKS, C.; RAMOS, L.; REEKIE, T.; MISAGH, G. H.; NARLAWAR, R.; KASSIOU, M.; MCGREGOR, I. S. Body temperature and cardiac changes induced by peripherally administered oxytocin, vasopressin and the non-peptide oxytocin receptor agonist WAY 267,464: a biotelemetry study in rats. British Journal of Pharmacology, v. 171, n. 11, p. 2868-2887, jun. 2014.

HOTT, S. C.; GOMES, F. V.; FABRI, D. R. S.; REIS, D. G.; CRESTANI, C. C.; CÔRREA, F. M. A.; RESSTEL, L. B. M. Both $\alpha 1$ - and $\beta 1$-adrenoceptors in the bed nucleus of the stria terminalis are involved in the expression of conditioned contextual fear. British Journal of Pharmacology, v. 167, n. 1, p. 207-221, set. 2012.

HÜBNER, C.; BOSCH, D.; GALL, A.; LÜTHI, A.; EHRLICH, I. Ex vivo dissection of optogenetically activated mPFC and hippocampal inputs to neurons in the basolateral amygdala: implications for fear and emotional memory. Frontiers in Behavioral Neuroscience, v. 8, p. 64, 2014.

IZQUIERDO, A.; WELLMAN, C. L.; HOLMES, A. Brief uncontrollable stress causes dendritic retraction in infralimbic cortex and resistance to fear extinction in mice. The Journal of Neuroscience: The Official Journal of the Society for Neuroscience, v. 26, n. 21, p. 5733-5738, 24 maio 2006.

IZQUIERDO, I. Memória Iván Izquierdo. Porto Alegre: ARTMED, 2002.

IZQUIERDO, I. The Art of Forgetting. Cham: Springer International Publishing, 2015. 
IZQUIERDO, I.; BARROS, D. M.; MELLO E SOUZA, T.; SOUZA, M. M. DE; IZQUIERDO, L. A.; MEDINA, J. H. Mechanisms for memory types differ. Nature, v. 393, n. 6686, p. 635-636, 18 jun. 1998.

IZQUIERDO, I.; FURINI, C. R. G.; MYSKIW, J. C. Fear Memory. Physiological Reviews, v. 96, n. 2, p. 695-750, abr. 2016.

IZQUIERDO, I.; MEDINA, J. H.; VIANNA, M. R.; IZQUIERDO, L. A.; BARROS, D. M. Separate mechanisms for short- and long-term memory. Behavioural brain research, v. 103, n. 1, p. 1-11, ago. 1999.

IZQUIERDO, I.; VIANNA, M. R. M.; IZQUIERDO, L. A.; BARROS, D. M.; SZAPIRO, G.; COITINHO, A. S.; MULLER, L.; CAMMAROTA, M.; BEVILAQUA, L. R. M.; MEDINA, J. H. Memory retrieval and its lasting consequences. Neurotoxicity Research, v. 4, n. 5-6, p. 573-593, set. 2002.

IZQUIERDO, L. A.; BARROS, D. M.; MEDINA, J. H.; IZQUIERDO, I. Stress hormones enhance retrieval of fear conditioning acquired either one day or many months before. Behavioural pharmacology, v. 13, n. 3, p. 203-213, maio 2002.

JOHANSEN, J. P.; CAIN, C. K.; OSTROFF, L. E.; LEDOUX, J. E. Molecular Mechanisms of Fear Learning and Memory. Cell, v. 147, n. 3, p. 509-524, out. 2011.

KAOUANE, N.; PORTE, Y.; VALLEE, M.; BRAYDA-BRUNO, L.; MONS, N.; CALANDREAU, L.; MARIGHETTO, A.; PIAZZA, P. V.; DESMEDT, A. Glucocorticoids Can Induce PTSD-Like Memory Impairments in Mice. Science, v. 335, n. 6075, p. 1510-1513, 23 fev. 2012.

KAPLAN, G. B.; MOORE, K. A. The use of cognitive enhancers in animal models of fear extinction. Pharmacology Biochemistry and Behavior, v. 99, n. 2, p. 217-228, ago. 2011.

KINDT, M. The surprising subtleties of changing fear memory: a challenge for translational science. Philosophical Transactions of the Royal Society B: Biological Sciences, v. 373, n. 1742, p. 20170033, 19 mar. 2018.

KINNER, V. L.; MERZ, C. J.; LISSEK, S.; WOLF, O. T. Cortisol disrupts the neural correlates of extinction recall. Neurolmage, v. 133, p. 233-243, jun. 2016.

KLOET, E. R. DE. Stress in the brain. European Journal of Pharmacology, v. 405, n. 1-3, p. 187-198, 29 set. 2000. 
KLOET, E. R. DE. From receptor balance to rational glucocorticoid therapy. Endocrinology, v. 155, n. 8, p. 2754-2769, ago. 2014.

KLOET, E. R. DE; KLOET, S. F. DE; KLOET, C. S. DE; KLOET, A. D. DE. Top-down and bottom-up control of stress-coping. Journal of Neuroendocrinology, p. e12675, 22 dez. 2018.

KLOK, M. D.; ALT, S. R.; IRURZUN LAFITTE, A. J. M.; TURNER, J. D.; LAKKE, E. A. J. F.; HUITINGA, I.; MULLER, C. P.; ZITMAN, F. G.; KLOET, E. R. DE; DERIJK, R. H. Decreased expression of mineralocorticoid receptor mRNA and its splice variants in postmortem brain regions of patients with major depressive disorder. Journal of Psychiatric Research, v. 45, n. 7, p. 871-878, jul. 2011.

KNOX, D.; NAULT, T.; HENDERSON, C.; LIBERZON, I. Glucocorticoid receptors and extinction retention deficits in the single prolonged stress model. Neuroscience, $v$. 223, p. 163-173, 25 out. 2012.

KOLB, B.; WHISHAW, I. Q. Neurociência do comportamento. Barueri: Manole, 2002.

KOLBER, B. J.; WIECZOREK, L.; MUGLIA, L. J. Hypothalamic-pituitary-adrenal axis dysregulation and behavioral analysis of mouse mutants with altered glucocorticoid or mineralocorticoid receptor function. Stress (Amsterdam, Netherlands), v. 11, n. 5, p. 321-338, set. 2008.

KOMPUS, K.; OLSSON, C.-J.; LARSSON, A.; NYBERG, L. Dynamic switching between semantic and episodic memory systems. Neuropsychologia, v. 47, n. 11, p. 2252-2260, set. 2009.

LALUMIERE, R. T.; MCGAUGH, J. L.; MCINTYRE, C. K. Emotional Modulation of Learning and Memory: Pharmacological Implications. Pharmacological Reviews, v. 69, n. 3, p. 236-255, jul. 2017.

LAMPRECHT, R.; LEDOUX, J. Structural plasticity and memory. Nature Reviews Neuroscience, v. 5, n. 1, p. 45-54, jan. 2004.

LASS-HENNEMANN, J.; MICHAEL, T. Endogenous cortisol levels influence exposure therapy in spider phobia. Behaviour Research and Therapy, v. 60, p. 39-45, set. 2014.

LEDOUX, J. E. Emotion circuits in the brain. Annual Review of Neuroscience, v. 23, p. $155-184,2000$. 
LEE, J. L. C.; NADER, K.; SCHILLER, D. An Update on Memory Reconsolidation Updating. Trends in Cognitive Sciences, v. 21, n. 7, p. 531-545, jul. 2017.

LEMOS, J. I.; RESSTEL, L. B.; GUIMARÃES, F. S. Involvement of the prelimbic prefrontal cortex on cannabidiol-induced attenuation of contextual conditioned fear in rats. Behavioural Brain Research, v. 207, n. 1, p. 105-111, 11 fev. 2010.

LISBOA, S. F.; GOMES, F. V.; SILVA, A. L.; ULIANA, D. L.; CAMARGO, L. H. A.; GUIMARÃES, F. S.; CUNHA, F. Q.; JOCA, S. R. L.; RESSTEL, L. B. M. Increased Contextual Fear Conditioning in iNOS Knockout Mice: Additional Evidence for the Involvement of Nitric Oxide in Stress-Related Disorders and Contribution of the Endocannabinoid System. The International Journal of Neuropsychopharmacology, v. 18, n. 8, 24 jan. 2015.

LISBOA, SABRINA F.; REIS, D. G.; SILVA, A. L. DA; CORREA, F. M. A.; GUIMARÃES, F. S.; RESSTEL, L. B. M. Cannabinoid CB1 receptors in the medial prefrontal cortex modulate the expression of contextual fear conditioning. The international journal of neuropsychopharmacology / official scientific journal of the Collegium Internationale Neuropsychopharmacologicum (CINP), v. 13, n. 9, p. 1163-1173, out. 2010.

LISBOA, S.F.; STECCHINI, M. F.; CORREAA, F. M. A.; GUIMARÃES, F. S.; RESSTEL, L. B. M. Different role of the ventral medial prefrontal cortex on modulation of innate and associative learned fear. Neuroscience, v. 171, n. 3, p. 760-768, dez. 2010.

LONSDORF, T. B.; HAAKER, J.; KALISCH, R. Long-term expression of human contextual fear and extinction memories involves amygdala, hippocampus and ventromedial prefrontal cortex: a reinstatement study in two independent samples. Social Cognitive and Affective Neuroscience, v. 9, n. 12, p. 1973-1983, dez. 2014.

LOPEZ, J.; GAMACHE, K.; SCHNEIDER, R.; NADER, K. Memory Retrieval Requires Ongoing Protein Synthesis and NMDA Receptor Activity-Mediated AMPA Receptor Trafficking. Journal of Neuroscience, v. 35, n. 6, p. 2465-2475, 11 fev. 2015.

LOPRESTO, D.; SCHIPPER, P.; HOMBERG, J. R. Neural circuits and mechanisms involved in fear generalization: Implications for the pathophysiology and treatment of posttraumatic stress disorder. Neuroscience \& Biobehavioral Reviews, v. 60, p. 3142, jan. 2016.

LU, Y.-L.; RICHARDSON, H. N. Alcohol, stress hormones, and the prefrontal cortex: A proposed pathway to the dark side of addiction. Neuroscience, 3 jul. 2014. 
MAKARA, G. B.; HALLER, J. Non-genomic effects of glucocorticoids in the neural system. Progress in Neurobiology, v. 65, n. 4, p. 367-390, nov. 2001.

MANDELA, P.; YAN, Y.; LARESE, T.; EIPPER, B. A.; MAINS, R. E. Elimination of Kalrn expression in POMC cells reduces anxiety-like behavior and contextual fear learning. Hormones and Behavior, v. 66, n. 2, p. 430-438, jul. 2014.

MAREN, S.; HOLMES, A. Stress and Fear Extinction. Neuropsychopharmacology, v. 41 , n. 1, p. 58-79, jan. 2016.

MAREN, S.; PHAN, K. L.; LIBERZON, I. The contextual brain: implications for fear conditioning, extinction and psychopathology. Nature Reviews Neuroscience, v. 14, n. 6, p. 417-428, 2 maio 2013.

MCEOWN, K.; TREIT, D. Mineralocorticoid receptors in the medial prefrontal cortex and hippocampus mediate rats' unconditioned fear behaviour. Hormones and Behavior, v. 60, n. 5, p. 581-588, nov. 2011.

MCGAUGH, J. L. Consolidating Memories. Annual Review of Psychology, v. 66, n. 1, p. 1-24, 3 jan. 2015.

MCGAUGH, J L; IZQUIERDO, I. The contribution of pharmacology to research on the mechanisms of memory formation. Trends in pharmacological sciences, v. $21, n .6$, p. 208-210, jun. 2000.

MCGAUGH, J. L.; IZQUIERDO, I. The contribution of pharmacology to research on the mechanisms of memory formation. Trends in Pharmacological Sciences, v. 21, $n$. 6, p. 208-210, jun. 2000.

MCKLVEEN, J. M.; MYERS, B.; FLAK, J. N.; BUNDZIKOVA, J.; SOLOMON, M. B.; SEROOGY, K. B.; HERMAN, J. P. Role of Prefrontal Cortex Glucocorticoid Receptors in Stress and Emotion. Biological Psychiatry, v. 74, n. 9, p. 672-679, nov. 2013.

MERZ, C. J.; HERMANN, A.; STARK, R.; WOLF, O. T. Cortisol modifies extinction learning of recently acquired fear in men. Social Cognitive and Affective Neuroscience, v. 9, n. 9, p. 1426-1434, set. 2014.

MERZ, C. J.; WOLF, O. T.; SCHWECKENDIEK, J.; KLUCKEN, T.; VAITL, D.; STARK, R. Stress differentially affects fear conditioning in men and women. Psychoneuroendocrinology, v. 38, n. 11, p. 2529-2541, nov. 2013. 
MEURET, A. E.; ROSENFIELD, D.; BHASKARA, L.; AUCHUS, R.; LIBERZON, I.; RITZ, T.; ABELSON, J. L. Timing matters: Endogenous cortisol mediates benefits from early-day psychotherapy. Psychoneuroendocrinology, v. 74, p. 197-202, 2016.

MEURET, A. E.; TRUEBA, A. F.; ABELSON, J. L.; LIBERZON, I.; AUCHUS, R.; BHASKARA, L.; RITZ, T.; ROSENFIELD, D. High cortisol awakening response and cortisol levels moderate exposure-based psychotherapy success. Psychoneuroendocrinology, v. 51, p. 331-340, jan. 2015.

MIKA, A.; MAZUR, G. J.; HOFFMAN, A. N.; TALBOOM, J. S.; BIMONTE-NELSON, H. A.; SANABRIA, F.; CONRAD, C. D. Chronic stress impairs prefrontal cortex-dependent response inhibition and spatial working memory. Behavioral Neuroscience, v. 126, n. 5, p. 605-619, 2012.

MILAD, M. R.; QUIRK, G. J. Fear Extinction as a Model for Translational Neuroscience: Ten Years of Progress. Annual Review of Psychology, v. 63, n. 1, p. 129-151, 10 jan. 2012.

MIYASHITA, T.; WILLIAMS, C. L. Peripheral arousal-related hormones modulate norepinephrine release in the hippocampus via influences on brainstem nuclei. Behavioural Brain Research, v. 153, n. 1, p. 87-95, ago. 2004.

MIZOGUCHI, K.; IKEDA, R.; SHOJI, H.; TANAKA, Y.; MARUYAMA, W.; TABIRA, T. Aging attenuates glucocorticoid negative feedback in rat brain. Neuroscience, v. 159, n. 1, p. 259-270, 3 mar. 2009.

MOENCH, K. M.; WELLMAN, C. L. Stress-induced alterations in prefrontal dendritic spines: Implications for post-traumatic stress disorder. Neuroscience Letters, dez. 2014.

MORRISON, F. G.; RESSLER, K. J. From the neurobiology of extinction to improved clinical treatments. Depression and Anxiety, v. 31, p. 279-290, 2014.

MUELLER, D.; CAHILL, S. P. Noradrenergic modulation of extinction learning and exposure therapy. Behavioural Brain Research, v. 208, n. 1, p. 1-11, mar. 2010.

MUELLER, D.; PORTER, J. T.; QUIRK, G. J. Noradrenergic Signaling in Infralimbic Cortex Increases Cell Excitability and Strengthens Memory for Fear Extinction. Journal of Neuroscience, v. 28, n. 2, p. 369-375, 9 jan. 2008.

MUSAZZI, L.; TORNESE, P.; SALA, N.; POPOLI, M. Acute or Chronic? A Stressful Question. Trends in Neurosciences, v. 40, n. 9, p. 525-535, 2017. 
MYERS, B.; MCKLVEEN, J. M.; HERMAN, J. P. Glucocorticoid actions on synapses, circuits, and behavior: implications for the energetics of stress. Frontiers in Neuroendocrinology, v. 35, n. 2, p. 180-196, abr. 2014.

MYSKIW, J. C.; IZQUIERDO, I.; FURINI, C. R. G. Modulation of the extinction of fear learning. Brain research bulletin, 14 abr. 2014.

NADER, K. Reconsolidation and the Dynamic Nature of Memory. Cold Spring Harbor Perspectives in Biology, v. 7, n. 10, p. a021782, out. 2015.

NAVA, N.; TRECCANI, G.; ALABSI, A.; KAASTRUP MUELLER, H.; ELFVING, B.; POPOLI, M.; WEGENER, G.; NYENGAARD, J. R. Temporal Dynamics of Acute Stress-Induced Dendritic Remodeling in Medial Prefrontal Cortex and the Protective Effect of Desipramine. Cerebral Cortex, p. bhv254, 1 nov. 2015.

NAVARRO-ZARAGOZA, J.; HIDALGO, J. M.; LAORDEN, M. L.; MILANÉS, M. V. Glucocorticoid receptors participate in the opiate withdrawal-induced stimulation of rats NTS noradrenergic activity and in the somatic signs of morphine withdrawal: Glucocorticoid receptor and opiate withdrawal. British Journal of Pharmacology, v. 166, n. 7, p. 2136-2147, ago. 2012.

OITZL, M. S.; CHAMPAGNE, D. L.; VEEN, R. VAN DER; KLOET, E. R. DE. Brain development under stress: Hypotheses of glucocorticoid actions revisited. Neuroscience \& Biobehavioral Reviews, v. 34, n. 6, p. 853-866, maio 2010.

OLIVEIRA, A. R. DE; REIMER, A. E.; BRANDÃO, M. L. Mineralocorticoid receptors in the ventral tegmental area regulate dopamine efflux in the basolateral amygdala during the expression of conditioned fear. Psychoneuroendocrinology, v. 43, p. 114-125, maio 2014.

OLIVEIRA, C. C.; SEPULVEDA, A. T.; ALMEIDA, N.; WARDLE, B. L.; SILVA, J. M. DA; ROCHA, L. A. Implantable flexible pressure measurement system based on inductive coupling. IEEE transactions on bio-medical engineering, v. 62, n. 2, p. 680-687, fev. 2015.

ORSINI, C. A.; MAREN, S. Neural and cellular mechanisms of fear and extinction memory formation. Neuroscience \& Biobehavioral Reviews, v. 36, n. 7, p. 17731802, ago. 2012.

PARSONS, R. G.; RESSLER, K. J. Implications of memory modulation for posttraumatic stress and fear disorders. Nature Neuroscience, v. 16, n. 2, p. 146-153, 28 jan. 2013. 
PIZZORUSSO, T. Neuroscience. Erasing fear memories. Science (New York, N.Y.), v. 325 , n. 5945 , p. $1214-1215$, 4 set. 2009.

POPOLI, M.; YAN, Z.; MCEWEN, B. S.; SANACORA, G. The stressed synapse: the impact of stress and glucocorticoids on glutamate transmission. Nature Reviews. Neuroscience, v. 13, n. 1, p. 22-37, jan. 2012.

QI, X.-R.; KAMPHUIS, W.; WANG, S.; WANG, Q.; LUCASSEN, P. J.; ZHOU, J.-N.; SWAAB, D. F. Aberrant stress hormone receptor balance in the human prefrontal cortex and hypothalamic paraventricular nucleus of depressed patients. Psychoneuroendocrinology, v. 38, n. 6, p. 863-870, jun. 2013.

QUERVAIN, D. DE; SCHWABE, L.; ROOZENDAAL, B. Stress, glucocorticoids and memory: implications for treating fear-related disorders. Nature Reviews Neuroscience, v. 18, n. 1, p. 7-19, jan. 2017.

QUERVAIN, D. DE; WOLF, O. T.; ROOZENDAAL, B. Glucocorticoid-induced enhancement of extinction-from animal models to clinical trials. Psychopharmacology, 4 jan. 2019.

QUERVAIN, D. J.-F. DE; MARGRAF, J. Glucocorticoids for the treatment of posttraumatic stress disorder and phobias: A novel therapeutic approach. European Journal of Pharmacology, v. 583, n. 2-3, p. 365-371, abr. 2008.

QUEVEDO, J.; FEIER, G.; AGOSTINHO, F. R.; MARTINS, M. R.; ROESLER, R. Consolidação da memória e estresse pós-traumático. Revista Brasileira de Psiquiatria, v. 25, jun. 2003.

QUIRK, G. J. Less fear, more diversity. PLOS Biology, v. 15, n. 4, p. e2002079, 17 abr. 2017.

QUIRK, G. J.; GARCIA, R.; GONZÁLEZ-LIMA, F. Prefrontal mechanisms in extinction of conditioned fear. Biological Psychiatry, v. 60, n. 4, p. 337-343, 15 ago. 2006.

RAIO, C. M.; BRIGNONI-PEREZ, E.; GOLDMAN, R.; PHELPS, E. A. Acute stress impairs the retrieval of extinction memory in humans. Neurobiology of Learning and Memory, v. 112, p. 212-221, jul. 2014.

RAUCH, S. A. M.; DEFEVER, E.; FAVORITE, T.; DUROE, A.; GARRITY, C.; MARTIS, B.; LIBERZON, I. Prolonged exposure for PTSD in a Veterans Health Administration PTSD clinic. Journal of traumatic stress, v. 22, n. 1, p. 60-64, fev. 2009. 
RENOULT, L.; DAVIDSON, P. S. R.; PALOMBO, D. J.; MOSCOVITCH, M.; LEVINE, B. Personal semantics: at the crossroads of semantic and episodic memory. Trends in Cognitive Sciences, v. 16, n. 11, p. 550-558, nov. 2012.

RESCORLA, R. A. Spontaneous Recovery. Learning \& Memory, v. 11, n. 5, p. 501509, 1 set. 2004.

RESCORLA, ROBERT A. Spontaneous recovery varies inversely with the trainingextinction interval. Learning \& behavior, v. 32, n. 4, p. 401-408, nov. 2004.

RESSTEL, L. B. M.; CORREAA, F. M. A. Involvement of the medial prefrontal cortex in central cardiovascular modulation in the rat. Autonomic Neuroscience: Basic \& Clinical, v. 126-127, p. 130-138, 30 jun. 2006.

RESSTEL, L. B. M.; JOCA, S. R. L.; GUIMARÃES, F. G.; CORREAA, F. M. A. Involvement of medial prefrontal cortex neurons in behavioral and cardiovascular responses to contextual fear conditioning. Neuroscience, v. 143, n. 2, p. 377-385, dez. 2006.

RESSTEL, L. B. M.; TAVARES, R. F.; LISBOA, S. F. S.; JOCA, S. R. L.; CORREAA, F. M. A.; GUIMARÃES, F. S. 5-HT 1A receptors are involved in the cannabidiol-induced attenuation of behavioural and cardiovascular responses to acute restraint stress in rats. British Journal of Pharmacology, v. 156, n. 1, p. 181-188, jan. 2009.

RISHER, W. C.; USTUNKAYA, T.; SINGH ALVARADO, J.; EROGLU, C. Rapid Golgi Analysis Method for Efficient and Unbiased Classification of Dendritic Spines. PLoS ONE, v. 9, n. 9, p. e107591, 10 set. 2014.

RODRIGUES, G. M.; TOFFOLI, L. V.; MANFREDO, M. H.; FRANCIS-OLIVEIRA, J.; SILVA, A. S.; RAQUEL, H. A.; MARTINS-PINGE, M. C.; MOREIRA, E. G.; FERNANDES, K. B.; PELOSI, G. G.; GOMES, M. V. Acute stress affects the global DNA methylation profile in rat brain: Modulation by physical exercise. Behavioural Brain Research, v. 279, p. 123-128, 15 fev. 2015.

RODRIGUEZ-ORTIZ, C. J.; BALDERAS, I.; GARCIA-DELATORRE, P.; BERMUDEZRATTONI, F. Taste aversion memory reconsolidation is independent of its retrieval. Neurobiology of Learning and Memory, v. 98, n. 3, p. 215-219, out. 2012.

ROESLER, R.; SCHRÖDER, N. Cognitive enhancers: Focus on modulatory signaling influencing memory consolidation. Pharmacology Biochemistry and Behavior, $v$. 99, n. 2, p. 155-163, ago. 2011. 
ROOZENDAAL, B.; MCGAUGH, J. L. Glucocorticoid receptor agonist and antagonist administration into the basolateral but not central amygdala modulates memory storage. Neurobiology of learning and memory, v. 67, n. 2, p. 176-179, mar. 1997.

ROSA, J.; MYSKIW, J. C.; FURINI, C. R. G.; SAPIRAS, G. G.; IZQUIERDO, I. Fear extinction can be made state-dependent on peripheral epinephrine: role of norepinephrine in the nucleus tractus solitarius. Neurobiology of Learning and Memory, v. 113, p. 55-61, set. 2014.

ROUGEMONT-BÜCKING, A.; LINNMAN, C.; ZEFFIRO, T. A.; ZEIDAN, M. A.; LEBRON-MILAD, K.; RODRIGUEZ-ROMAGUERA, J.; RAUCH, S. L.; PITMAN, R. K.; MILAD, M. R. Altered processing of contextual information during fear extinction in PTSD: an fMRI study. CNS neuroscience \& therapeutics, v. 17, n. 4, p. 227-236, ago. 2011.

SACHSER, R. M.; CRESTANI, A. P.; QUILLFELDT, J. A.; MELLO E SOUZA, T.; OLIVEIRA ALVARES, L. DE. The cannabinoid system in the retrosplenial cortex modulates fear memory consolidation, reconsolidation, and extinction. Learning \& Memory (Cold Spring Harbor, N.Y.), v. 22, n. 12, p. 584-588, dez. 2015.

SANDI, C. Stress and cognition. Wiley Interdisciplinary Reviews. Cognitive Science, v. 4, n. 3, p. 245-261, maio 2013.

SANTINI, E. Consolidation of Fear Extinction Requires Protein Synthesis in the Medial Prefrontal Cortex. Journal of Neuroscience, v. 24, n. 25, p. 5704-5710, 23 jun. 2004.

SANTOS, M. E. P. et al. Hypotensive and vasorelaxant effects induced by the ethanolic extract of the Mimosa caesalpiniifolia Benth. (Mimosaceae) inflorescences in normotensive rats. Journal of Ethnopharmacology, v. 164, p. 120-128, 22 abr. 2015.

SAPOLSKY, R. M. Stress and the brain: individual variability and the inverted-U. Nature Neuroscience, v. 18, n. 10, p. 1344-1346, out. 2015.

SCHAFE, G. E.; LEDOUX, J. E. Memory consolidation of auditory pavlovian fear conditioning requires protein synthesis and protein kinase $A$ in the amygdala. The Journal of Neuroscience: The Official Journal of the Society for Neuroscience, v. 20, n. 18, p. RC96, 15 set. 2000.

SCHILLER, D.; KANEN, J. W.; LEDOUX, J. E.; MONFILS, M.-H.; PHELPS, E. A. Extinction during reconsolidation of threat memory diminishes prefrontal cortex involvement. Proceedings of the National Academy of Sciences, v. 110, n. 50, p. 20040-20045, 25 nov. 2013. 
SCHUCHARD, J.; THOMPSON, C. K. Implicit and Explicit Learning in Individuals with Agrammatic Aphasia. Journal of Psycholinguistic Research, 27 mar. 2013.

SCHWABE, L.; NADER, K.; PRUESSNER, J. C. Reconsolidation of Human Memory: Brain Mechanisms and Clinical Relevance. Biological Psychiatry, v. 76, n. 4, p. 274280, ago. 2014.

SELYE, H. Forty years of stress research: principal remaining problems and misconceptions. Canadian Medical Association Journal, v. 115, n. 1, p. 53-56, 3 jul. 1976.

SINGEWALD, N.; SCHMUCKERMAIR, C.; WHITTLE, N.; HOLMES, A.; RESSLER, K.J. Pharmacology of cognitive enhancers for exposure-based therapy of fear, anxiety and trauma-related disorders. Pharmacology \& Therapeutics, dez. 2014.

SINGEWALD, N.; SCHMUCKERMAIR, C.; WHITTLE, N.; HOLMES, A.; RESSLER, K. J. Pharmacology of cognitive enhancers for exposure-based therapy of fear, anxiety and trauma-related disorders. Pharmacology \& Therapeutics, 27 dez. 2014.

SOLOMON, M. B.; WULSIN, A. C.; RICE, T.; WICK, D.; MYERS, B.; MCKLVEEN, J.; FLAK, J. N.; ULRICH-LAI, Y.; HERMAN, J. P. The selective glucocorticoid receptor antagonist CORT 108297 decreases neuroendocrine stress responses and immobility in the forced swim test. Hormones and Behavior, v. 65, n. 4, p. 363-371, abr. 2014.

SOUZA, R. R.; DAL BÓ, S.; KLOET, E. R. DE; OITZL, M. S.; CAROBREZ, A. P. Paradoxical mineralocorticoid receptor-mediated effect in fear memory encoding and expression of rats submitted to an olfactory fear conditioning task. Neuropharmacology, v. 79, p. 201-211, abr. 2014.

SQUIRE, L. R. Memory and Brain Systems: 1969-2009. Journal of Neuroscience, v. 29, n. 41, p. 12711-12716, 14 out. 2009.

STAHN, C.; BUTTGEREIT, F. Genomic and nongenomic effects of glucocorticoids. Nature Clinical Practice. Rheumatology, v. 4, n. 10, p. 525-533, out. 2008.

STOCKHORST, U.; ANTOV, M. I. Modulation of Fear Extinction by Stress, Stress Hormones and Estradiol: A Review. Frontiers in Behavioral Neuroscience, v. 9, 26 jan. 2016.

SUZUKI, A.; JOSSELYN, S. A.; FRANKLAND, P. W.; MASUSHIGE, S.; SILVA, A. J.; KIDA, S. Memory reconsolidation and extinction have distinct temporal and 
biochemical signatures. The Journal of Neuroscience: The Official Journal of the Society for Neuroscience, v. 24, n. 20, p. 4787-4795, 19 maio 2004.

SZABO, S.; TACHE, Y.; SOMOGYI, A. The legacy of Hans Selye and the origins of stress research: A retrospective 75 years after his landmark brief "Letter" to the Editor \# of Nature. Stress, v. 15, n. 5, p. 472-478, set. 2012.

SZAPIRO, G.; GALANTE, J. M.; BARROS, D. M.; LEVI DE STEIN, M.; VIANNA, M. R. M.; IZQUIERDO, L. A.; IZQUIERDO, I.; MEDINA, J. H. Molecular mechanisms of memory retrieval. Neurochemical Research, v. 27, n. 11, p. 1491-1498, nov. 2002.

TERZIAN, A. L. B.; REIS, D. G. DOS; GUIMARÃES, F. S.; CORREAA, F. M. A.; RESSTEL, L. B. M. Medial prefrontal cortex Transient Receptor Potential Vanilloid Type 1 (TRPV1) in the expression of contextual fear conditioning in Wistar rats. Psychopharmacology, v. 231, n. 1, p. 149-157, jan. 2014.

THORP, S. R.; STEIN, M. B.; JESTE, D. V.; PATTERSON, T. L.; WETHERELL, J. L. Prolonged exposure therapy for older veterans with posttraumatic stress disorder: a pilot study. The American journal of geriatric psychiatry: official journal of the American Association for Geriatric Psychiatry, v. 20, n. 3, p. 276-280, mar. 2012.

TRECCANI, G. et al. Stress and corticosterone increase the readily releasable pool of glutamate vesicles in synaptic terminals of prefrontal and frontal cortex. Molecular Psychiatry, v. 19, n. 4, p. 433-443, abr. 2014.

TSIGOS, C.; CHROUSOS, G. P. Hypothalamic-pituitary-adrenal axis, neuroendocrine factors and stress. Journal of Psychosomatic Research, v. 53, n. 4, p. 865-871, out. 2002.

ULIANA, D. L.; HOTT, S. C.; LISBOA, S. F.; RESSTEL, L. B. M. Dorsolateral periaqueductal gray matter CB1 and TRPV1 receptors exert opposite modulation on expression of contextual fear conditioning. Neuropharmacology, v. 103, p. 257-269, abr. 2016.

VANELZAKKER, M. B.; KATHRYN DAHLGREN, M.; CAROLINE DAVIS, F.; DUBOIS, S.; SHIN, L. M. From Pavlov to PTSD: The extinction of conditioned fear in rodents, humans, and anxiety disorders. Neurobiology of Learning and Memory, v. 113, p. 3-18, set. 2014.

VIANNA, M. R.; SZAPIRO, G.; MCGAUGH, J. L.; MEDINA, J. H.; IZQUIERDO, I. Retrieval of memory for fear-motivated training initiates extinction requiring protein synthesis in the rat hippocampus. Proceedings of the National Academy of Sciences of the United States of America, v. 98, n. 21, p. 12251-12254, 9 out. 2001. 
WICKING, M.; STEIGER, F.; NEES, F.; DIENER, S. J.; GRIMM, O.; RUTTORF, M.; SCHAD, L. R.; WINKELMANN, T.; WIRTZ, G.; FLOR, H. Deficient fear extinction memory in posttraumatic stress disorder. Neurobiology of Learning and Memory, $v$. 136, p. 116-126, dez. 2016.

WOLF, O. T.; ATSAK, P.; QUERVAIN, D. J. DE; ROOZENDAAL, B.; WINGENFELD, K. Stress and Memory: A Selective Review on Recent Developments in the Understanding of Stress Hormone Effects on Memory and Their Clinical Relevance. Journal of Neuroendocrinology, v. 28, n. 8, ago. 2016.

WU, J.; YAN, J. Editorial: Stress and Cognition. Frontiers in Psychology, v. 8, 9 jun. 2017.

XING, G.-Q.; RUSSELL, S.; WEBSTER, M. J.; POST, R. M. Decreased expression of mineralocorticoid receptor mRNA in the prefrontal cortex in schizophrenia and bipolar disorder. The international journal of neuropsychopharmacology I official scientific journal of the Collegium Internationale Neuropsychopharmacologicum (CINP), v. 7, n. 2, p. 143-153, jun. 2004. 
APÊNDICE A - Estudo piloto

Inicialmente para aferir os efeitos sustentados do estresse sobre o perfil da extinção da memória de medo condicionado contextual, foram testados diferentes tempos de exposição dos animais ao estresse por restrição, bem como diferentes tempos para a sessão de condicionamento, extinção e teste, diferentes intervalos entre o estresse por restrição e o protocolo de extinção do MCC, e também diferentes intensidades do estímulo aversivo durante a sessão de condicionamento (número de choques e intensidade). Isto para que nós pudéssemos observar efeitos do estresse agudo por restrição no processo de extinção e estudar os mecanismos destes efeitos. Considerando que o estresse apresenta efeito dual sobre a cognição (efeito benéfico ou deletério) e que este efeito dual é variável de acordo com o tempo de exposição e a intensidade do estímulo estressor, foi importante estes diferentes ensaios, para decidirmos com qual protocolo trabalhar os objetivos deste estudo.

Deste modo, inicialmente nós avaliamos o papel de uma única sessão de exposição a um evento estressor sobre o perfil de extinção da memória de medo em animais condicionados ao contexto, testando dois intervalos: protocolos de 7 ou 9 dias (contados a partir da exposição ao evento estressor até o teste do protocolo de extinção do condicionamento aversivo), bem como testamos diferentes tempos em que o animal permaneceu na sessão de estresse por restrição, 1 ou 3 horas. Iniciamos pelo protocolo de 7 dias conforme segue ilustração na figura 9A e 9B. Na figura 1C está representado o perfil da extinção em animais expostos ao estresse e animais expostos durante 1 ou 3 horas ao estresse por restrição, e que no quinto dia, a contar da data da exposição ao estresse, foi executado o protocolo de MCC. Ao submetermos os dados deste ensaio experimental, com duração de 7 dias, à análise estatística observamos que não houve interação entre os grupos $\left(F_{(10,190)}=0.85\right.$, $p=0,5808$ ) durante a sessão de extinção. No fator condição, (estresse por $1 \mathrm{~h}$, estresse por $3 \mathrm{~h}$ e não estresse), os animais que foram expostos durante 3 horas ao estresse por restrição apresentaram um aumento na expressão da memória de condicionamento aversivo durante a sessão de extinção $\left(F_{(2,190)}=4.37, p<, 005\right)$. Em relação ao fator tempo, observamos que todos os grupos (animais estressados por $1 \mathrm{~h}, \mathrm{n}=8$; animais estressados por $3 \mathrm{~h}, \mathrm{n}=16$, ou não estressados $n=17$ ), são capazes de adquirir a memória de extinção ao longo da sessão $\left(F_{(5,190)}=24.49, p<0,0001\right)$. Contudo, os animais estressados por 3 horas apresentaram déficit na consolidação 
da extinção da memória aversiva, visto que na sessão de teste da retenção desta nova memória adquirida, o animal se comporta como se não tivesse sido exposto a sessão de extinção, apresentando diferença significativa do percentual de freezing quando comparado ao grupo de animais não estressados $\left(F_{(2,38)}=5.3813 P<0,05\right)$.
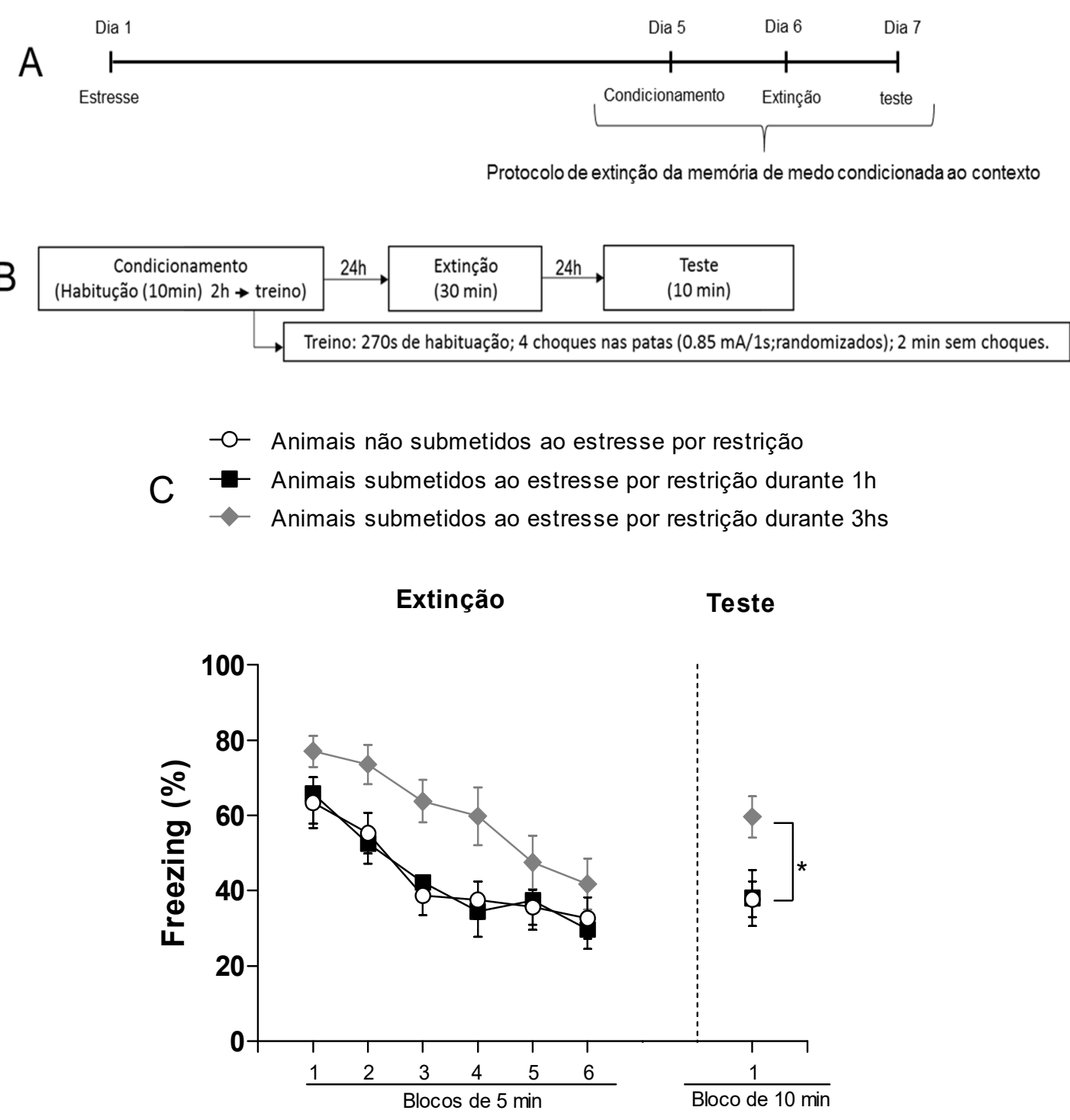

Figura 9. Perfil de extinção da memória de medo condicionado ao contexto em animais estressados e não estressados (estudo piloto- ensaio 1): (A). Representação esquemática do intervalo de tempo entre os procedimentos comportamentais. (B). Representação esquemática do protocolo de extinção da memória de condicionamento aversivo. (C). Os símbolos representam a média e as barras \pm o EPM. $\mathrm{n}=8-20$ por grupo. ${ }^{*} \mathrm{p}<0,05=$ grupo estressado por $3 \mathrm{~h}$ versus grupo não estressado (ANOVA de uma via seguido do pós-teste de Newman-Keuls). 
No primeiro ensaio realizado (Figura 9, como não sabíamos que os animais apresentariam diferença na expressão do medo condicionado, nós aferimos o freezing dos animais somente durante a sessão de extinção e teste. Porém, ao verificarmos que os animais estressados se comportavam de maneira distinta já durante os primeiros minutos da sessão de extinção, nossa indagação foi se os animais estressados estariam apresentando diferença no comportamento já durante a sessão de condicionamento. Assim, decidimos registrar o freezing dos animais também durante a sessão de condicionamento nos ensaios comportamentais seguintes.

Ao considerar que na literatura científica os modelos propostos para o estudo do PTSD, envolvendo a exposição de roedores a agentes estressores antes do condicionamento aversivo, apresentam um intervalo de dias maior entre estes dois eventos, e, na tentativa de que estes dois eventos sejam dissociados entre si, decidimos testar um protocolo de 9 dias. Decidimos também, a partir do protocolo de 9 dias, registrar o percentual de freezing apresentado pelos animais também na sessão de condicionamento, visto que já iniciamos o experimento com animais em duas condições diferentes (estressados e não estressados). O protocolo seguido está representado na Figura $10 \mathrm{~A}$ e B. Na figura 10C, podemos observar que durante a aquisição da memória de condicionamento os animais estressados por $1 \mathrm{~h}(\mathrm{n}=7)$, estressados por $3 h(n=8)$ e não estressados $(n=6)$ apresentaram um progressivo aumento na resposta de freezing ao longo do tempo $\left(F_{(4,72)}=42.18, p<0,0001\right)$, não havendo interação entre os grupos $\left(F_{(8,72)}=1.38, p<0,2189\right)$, ou efeito do fator condição $\left(F_{(2,72)}=0.50, p=0,6119\right)$. Contudo, na sessão de extinção, em relação ao fator condição, diferente do protocolo de 5 dias, aqui nós observamos que foram os animais expostos durante 1 hora ao estresse por restrição que apresentaram um aumento na expressão da memória de condicionamento aversivo durante a sessão de extinção $\left(F_{(2,90)}=7.69 p<, 005\right)$; não havendo interação entre os grupos $\left(F_{(10,90)}=0.72\right.$ $p=0,7053)$. $E$ apesar de todos os grupos adquirirem a memória de extinção ao longo da sessão $\left(F_{(5,90)}=20.62, p<, 00001\right)$, os animais expostos ao estresse por restrição durante 1 hora apresentam déficit na consolidação da memória de extinção $\left(F_{(2,18)}=\right.$ $4,261, \mathrm{P}<0,05)$. 


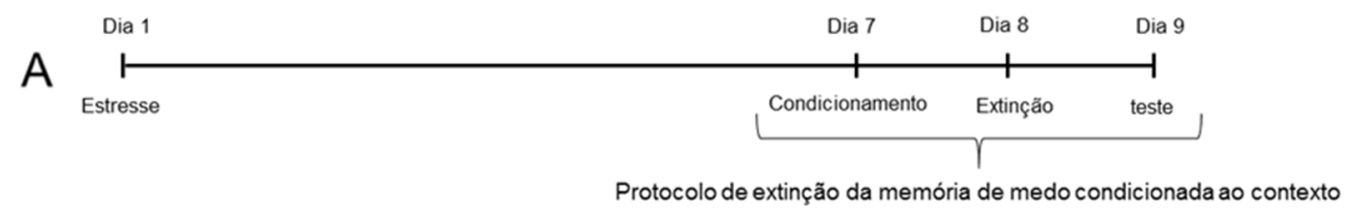

B

\begin{tabular}{c|c|c|c|}
$\begin{array}{c}\text { Condicionamento } \\
\text { (Habitução (10min) } 2 \mathrm{~h} \rightarrow \text { treino) }\end{array} \stackrel{24 \mathrm{~h}}{\longrightarrow} \begin{array}{l}\text { Extinção } \\
(30 \mathrm{~min})\end{array}$
\end{tabular}

Treino: 270 s de habituação; 4 choques nas patas ( $0.85 \mathrm{~mA} / 1 \mathrm{~s} ;$ randomizados); 2 min sem choques.

$-\leftarrow$ Animais não submetidos ao estresse por restrição
$-\downarrow$ Animais submetidos ao estresse por restrição durante 1h
- Animais submetidos ao estresse por restrição durante 3hs

Condicionamento

Extinção

Teste

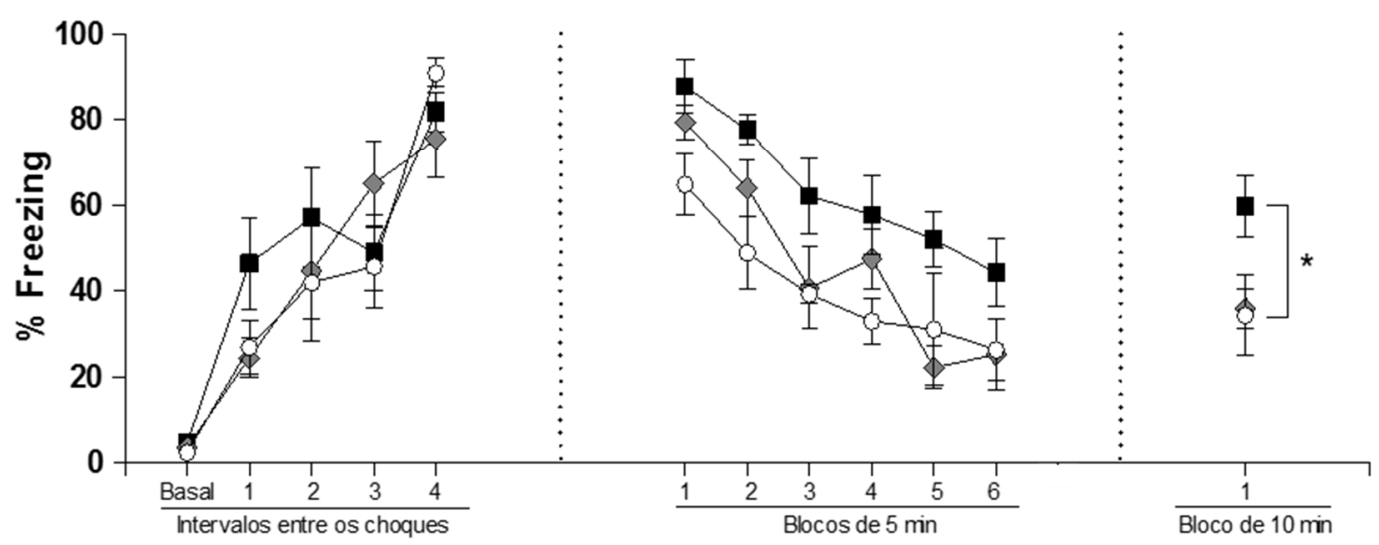

Figura 10. Perfil de extinção da memória de medo condicionado em animais estressados e não estressados (estudo piloto - ensaio 2). (A). Representação esquemática do intervalo de tempo entre os procedimentos comportamentais. (B). Representação esquemática do protocolo de extinção da memória de condicionamento aversivo. (C). Os símbolos representam a média e as barras \pm o EPM. $n=6-8$ por grupo. ${ }^{*} p<0,05=$ grupo estressado por $1 \mathrm{~h}$ versus grupo não estressado (ANOVA de uma via seguido do pós-teste de Newman-Keuls).

A partir dos resultados obtidos decidimos utilizar o protocolo de 9 dias nos ensaios experimentais seguintes, devido a maior robustez dos dados observado nesta condição, mantendo o grupo de animais não submetidos ao estresse e o grupo de animais submetidos ao estresse agudo durante 1 hora, a fim de se estudar o envolvimento dos receptores glicocorticoides e mineracorticoides presentes nas porções PL e IL do CPFvm nestas duas condições, e assim, tentar compreender um pouco sobre os mecanismos envolvidos no déficit de extinção do MCC mediante o estresse agudo prévio. 
Estes primeiros ensaios comportamentais foram realizados mantendo-se 4 animais por caixa moradia, mantendo animais agrupados por condição: estressados e não estressados. Porém, a partir do momento em que realizássemos a cirurgia de canulação da aorta abdominal dos animais, para coleta de amostras de sangue para análise dos níveis de corticosterona, ou inserção da sonda rádio-telemétrica para aferição das respostas autonômicas de PAM e FC, seria necessário o isolamento dos animais após este procedimento cirúrgico. Nossa preocupação inicial foi se o isolamento dos animais ocasionaria algum impacto nas respostas comportamentais observadas até o presente momento. Testamos diferentes metodologias para viabilidade da cirurgia, realizando-a em diferentes momentos do ensaio comportamental, e o protocolo foi padronizado como está descrito na Figura 7 das Considerações Finais desta Tese. Na figura 11C, podemos observar que o isolamento dos animais não estressados e estressados, a partir da execução da cirurgia para inserção de um cateter e polietileno para coleta de sangue ou sonda rádio-telemétrica, não alterou o perfil comportamental observado na figura 10C. Durante a aquisição da memória de condicionamento os animais estressados $(n=4)$ e não estressados $(n=5)$ apresentam um progressivo aumento na resposta de freezing ao longo do tempo $\left(F_{(4,28)}=13.03\right.$, $\left.p<0,0001\right)$, não havendo interação entre os grupos $\left(F_{(4,28)}=0.96\right.$, $p=0,4459)$, ou efeito do fator condição $\left(F_{(1,28)}=0.03, p=0,8609\right)$. Os animais submetidos ao estresse por restrição durante $1 \mathrm{~h}$ apresentaram um aumento na expressão da memória de condicionamento aversivo durante a sessão de extinção $\left(F_{(1,35)}=8.69\right.$ $p<, 005)$, mas ambos os grupos adquirirem a memória de extinção ao longo da sessão $\left(F_{(5,35)}=9.28\right.$, p<,00001), não havendo interação entre os grupos $\left(F_{(5,35)}=1.52\right.$, $p=0,2093)$. Os animais expostos ao estresse por restrição durante 1 hora apresentam déficit na consolidação da memória de extinção $(t=2.470 \mathrm{df}=7, \mathrm{P}<0,05)$. 


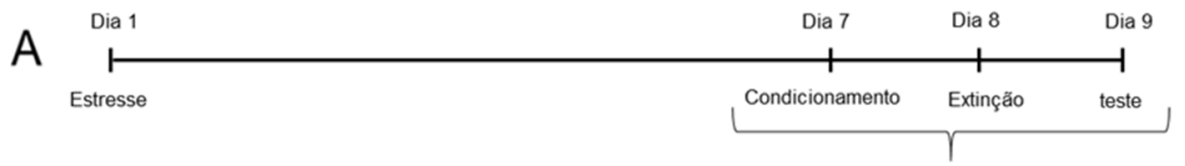

Protocolo de extinção da memória de medo condicionada ao contexto

B

\begin{tabular}{|c|c|c|c|c|}
\hline $\begin{array}{l}\text { Condicionamento } \\
\text { (Habitução }(10 \mathrm{~min}) 2 \mathrm{~h} \rightarrow \text { treino })\end{array}$ & $24 \mathrm{~h}$ & $\begin{array}{l}\text { Extinção } \\
\text { (30 min) }\end{array}$ & $24 \mathrm{~h}$ & $\begin{array}{l}\text { Teste } \\
(10 \mathrm{~min})\end{array}$ \\
\hline
\end{tabular}

Treino: 270 s de habituação; 4 choques nas patas ( $0.85 \mathrm{~mA} / 1 \mathrm{~s}$;randomizados); 2 min sem choques.

C - Animais não submetidos ao estresse por restrição

Animais submetidos ao estresse por restrição durante $1 \mathrm{~h}$

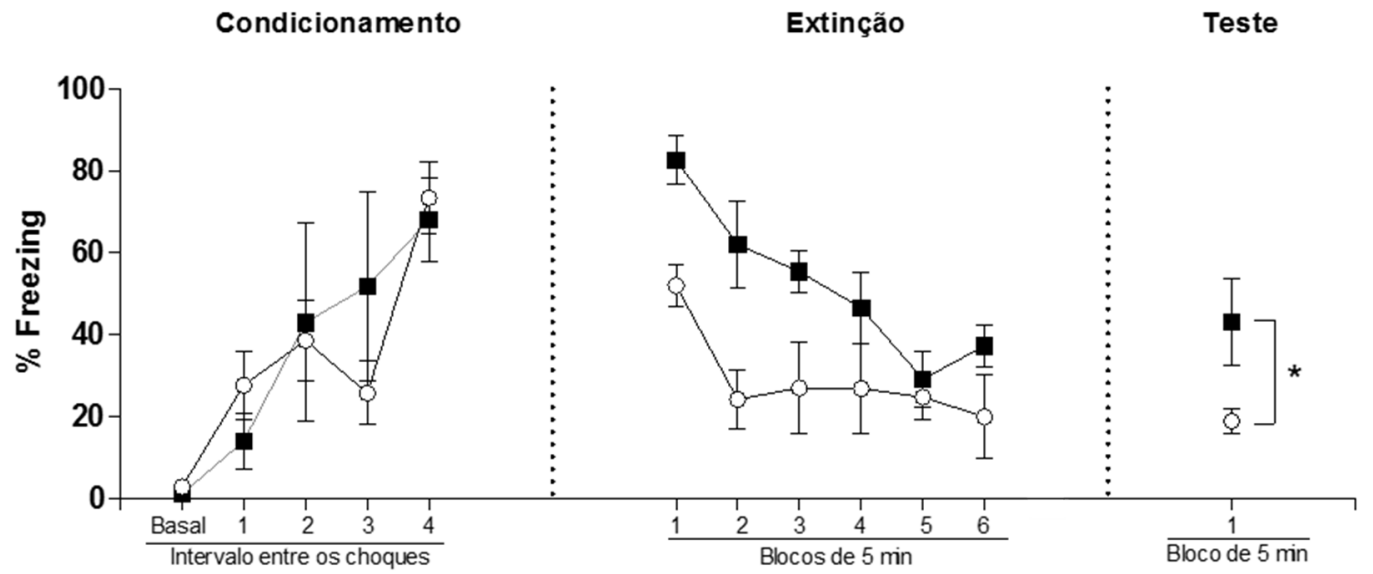

Figura 11. Perfil de extinção da memória de medo condicionado ao contexto em animais estressados e não estressados mantidos em regime de isolamento (estudo piloto - ensaio 3). (A). Representação esquemática do intervalo de tempo entre os procedimentos comportamentais. (B). Representação esquemática do protocolo de extinção da memória de condicionamento aversivo. (C). Os símbolos representam a média e as barras \pm o EPM. $n=4-5$ por grupo. ${ }^{*} p<0,05=$ grupo estressado por $1 \mathrm{~h}$ versus grupo não estressado (analisado por meio do teste t de Student).

Ainda com o intuito de otimizar o tempo para a realização do ensaio comportamental de MCC, decidimos reduzir o tempo de extinção para $20 \mathrm{~min}$, modificando ou não a aversividade do protocolo de condicionamento (alterando ou não o número e o tempo da emissão de estímulos elétricos nas patas dos animais durante a sessão de condicionamento). Também retiramos os 10 min de habituação no dia do condicionamento, e diminuímos o tempo da sessão de teste de 10 para 5 min, a fim de garantir que o teste seja breve e garanta apenas a evocação da memória de extinção e não uma eventual segunda sessão de extinção. 
No gráfico 4C, foram realizadas alterações no protocolo demonstrado na Figura 10A e B: foi retirado os 10 min de habituação antes do treino do condicionamento, diminuído o número e a duração dos estímulos elétricos emitidos nas patas dos animais para a realização do condicionamento (2 choques de $0,5 \mathrm{~mA}$ com duração de 2s cada e intervalo de 30s entre eles), e diminuído o tempo de exposição do animal a sessão de extinção. Neste caso, não observamos a performance comportamental observada no protocolo anterior (Figura 10A e B). Durante a aquisição da memória de condicionamento os animais estressados $(n=7)$ e não estressados $(n=6)$ apresentam um progressivo aumento na resposta de freezing ao longo do tempo $\left(F_{(2,22)}=23.25\right.$, $p<, 00001)$, não havendo interação entre os grupos $\left(F_{(2,22)}=1.34, p=0,3172\right)$ ou efeito do fator condição $\left(F_{(1,22)}=1.10, p=0,3172\right)$. Os animais submetidos ao estresse por restrição durante $1 \mathrm{~h}$ não apresentaram aumento na expressão da memória de condicionamento aversivo durante a sessão de extinção $\left(F_{(1,33)}=1.79, p=0,2083\right)$, mas ambos os grupos adquirirem a memória de extinção ao longo da sessão $\left(F_{(3,33)}=18.27\right.$, $p<, 00001)$. Os animais expostos ao estresse por restrição durante 1 hora não apresentaram déficit na consolidação da memória de extinção ( $t=0,4977$ df=11; teste t de Student). 


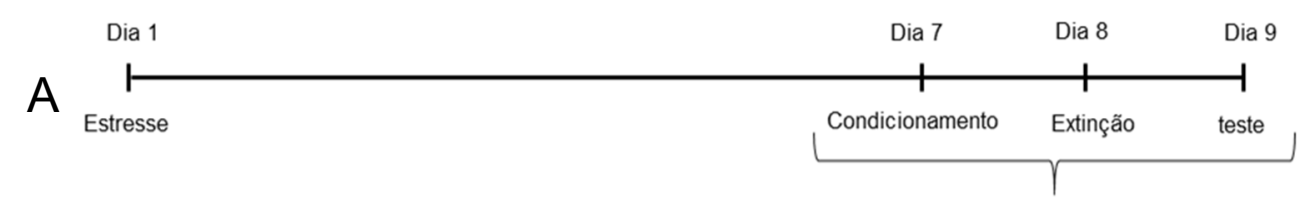

Protocolo de extinção da memória de medo condicionada ao contexto

B

\begin{tabular}{|c|c|c|c|c|}
\hline $\begin{array}{l}\text { Condicionamento } \\
\text { (5 min) }\end{array}$ & $24 \mathrm{~h}$ & $\begin{array}{l}\text { Extinção } \\
\text { (20 min) }\end{array}$ & $24 \mathrm{~h}$ & $\begin{array}{l}\text { Teste } \\
\text { (5 min) }\end{array}$ \\
\hline
\end{tabular}

$2 \mathrm{~min}$ de habituação; 2 choques nas patas $(0.5 \mathrm{~mA} \mathrm{~mA} / 2 \mathrm{~s} / 30 \mathrm{~s}$ intervalo; 2 min sem choques.

C $\quad-$ Animais não submetidos ao estresse por restrição
- Animais submetidos ao estresse por restrição durante $1 \mathrm{~h}$

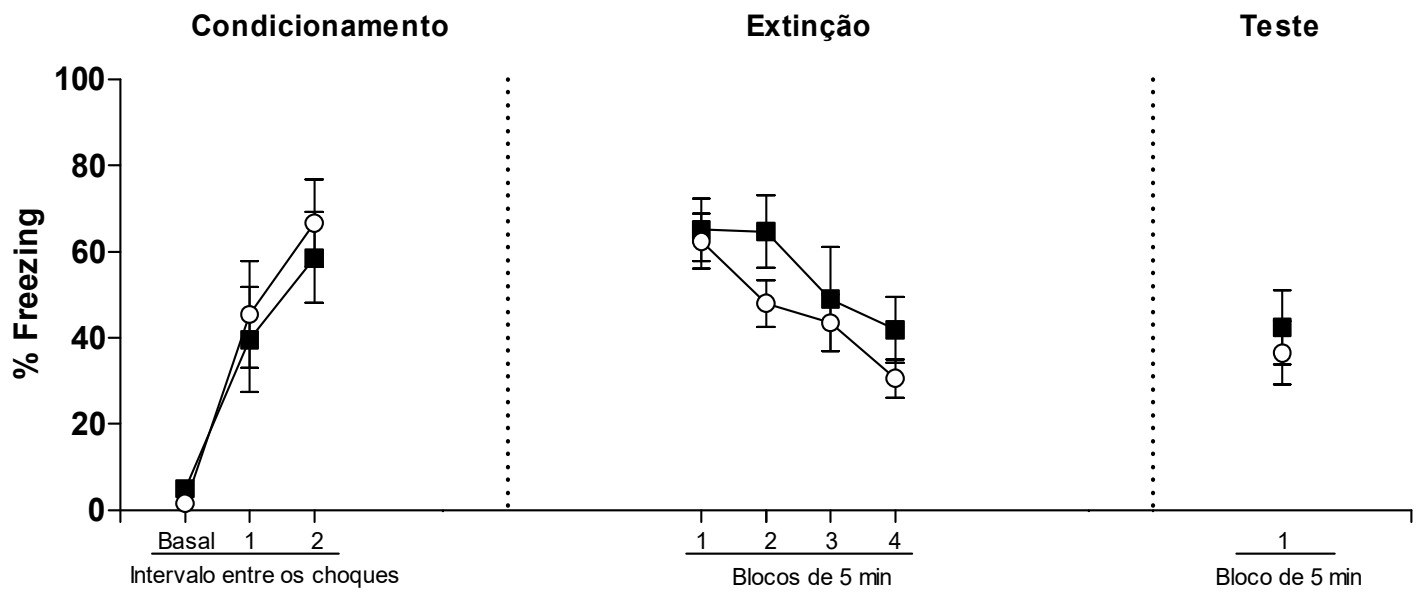

Figura 12. Perfil de extinção da memória de medo condicionado ao contexto e da retenção da memória de extinção em animais estressados e não estressados (estudo piloto - ensaio 4). (A). Representação esquemática do intervalo de tempo entre os procedimentos comportamentais. (B). Representação esquemática do protocolo de extinção da memória de condicionamento aversivo. (C). Os símbolos representam a média e as barras \pm o EPM. $n=6-7$ por grupo.

Contudo, na ausência de 10 min de habituação antes do condicionamento, extinção de 20 min e teste de retenção da memória de extinção em 5 min, mas sem alterar o número de estímulos elétricos emitidos nas patas dos animais do protocolo de 9 dias demonstrado na Figura 10A e B (4 choques de $0.85 \mathrm{~mA}$ com duração de $1 \mathrm{~s}$ em intervalos randomizados), conseguimos obter a performance comportamental almejada para a execução dos objetivos deste estudo, otimizando o tempo despendido para o ensaio comportamental conforme pode ser visto na Figura 1 no 
corpo de resultados desta Tese e descrita no item 3.14.1. na sessão dos Materiais e Métodos. 
ANEXO I - Carta de aprovação pelo Conselho Nacional de Controle de Experimentação Animal (CONSEA) do projeto que deu origem a esta Tese $\left(\mathrm{n}^{\circ}\right.$ 069/2015)
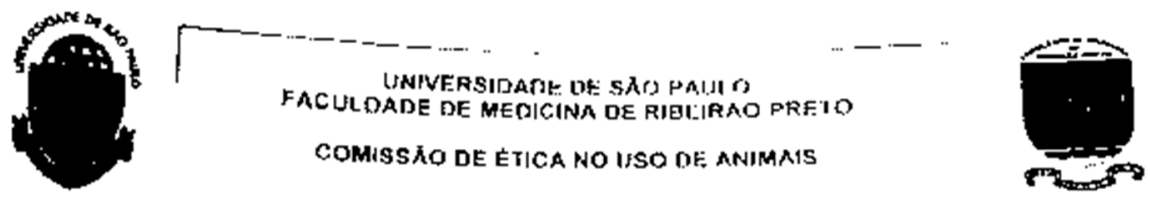

\section{CERTIFICADO}

Certificamos que o Protocolo para Uso de Animais em Experimentaça no $0^{\circ} 069 / 2015$, sobrc o projeto intitulado "O papel dor estresse agudo e dos receptores mineralocorticoides e glicocorticoides presentes no córtex préfronlal no processo de extinçąo de memória aversiva ", sob a responsabilidede do Professar Doutar Leonardo Resstel Barbosa Moraes está de acordo com os Princípios Éticos em Experimentação Animal adotado pelo Conselho Nacional de Controle de Experimentsçẳo Animal (CONCEA) c foi APROVADO em reuniāo de 31 de agosto de 2015.

\footnotetext{
We certify that the prosoco! n' O69/20Is, entitied "The role of acure stress and minerolocarticold and

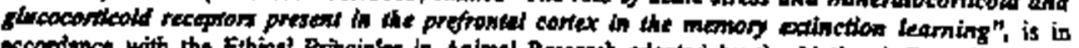
occoniance with the Ethical Principies in Animal Research adopted by the National Council for the Coatrol of Animai Experimentetion (CONCEA) and was approved by the Loeal Animal Ethica! Committe from the Ribeirio Preto Modical Sehool of the University of S\&o Paulo in $0231 / 201$ s.
}

Ribeirăo Preto, 31 de agosto de 2015.

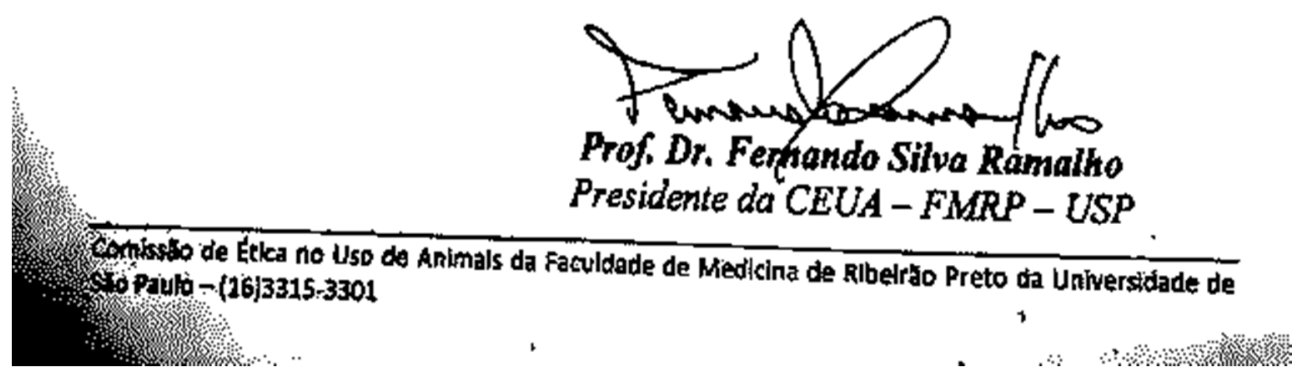




\section{ANEXO II - Ficha do aluno - Sistema Janus (Sistema administrativo da Pós- graduação) da USP}

$06 / 02 / 2019$

Janus - Sistema Administrativo da Pós-Graduação

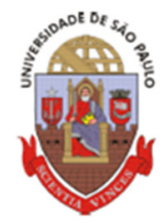

Universidade de São Paulo

Faculdade de Medicina de Ribeirão Preto

FICHA DO ALUNO

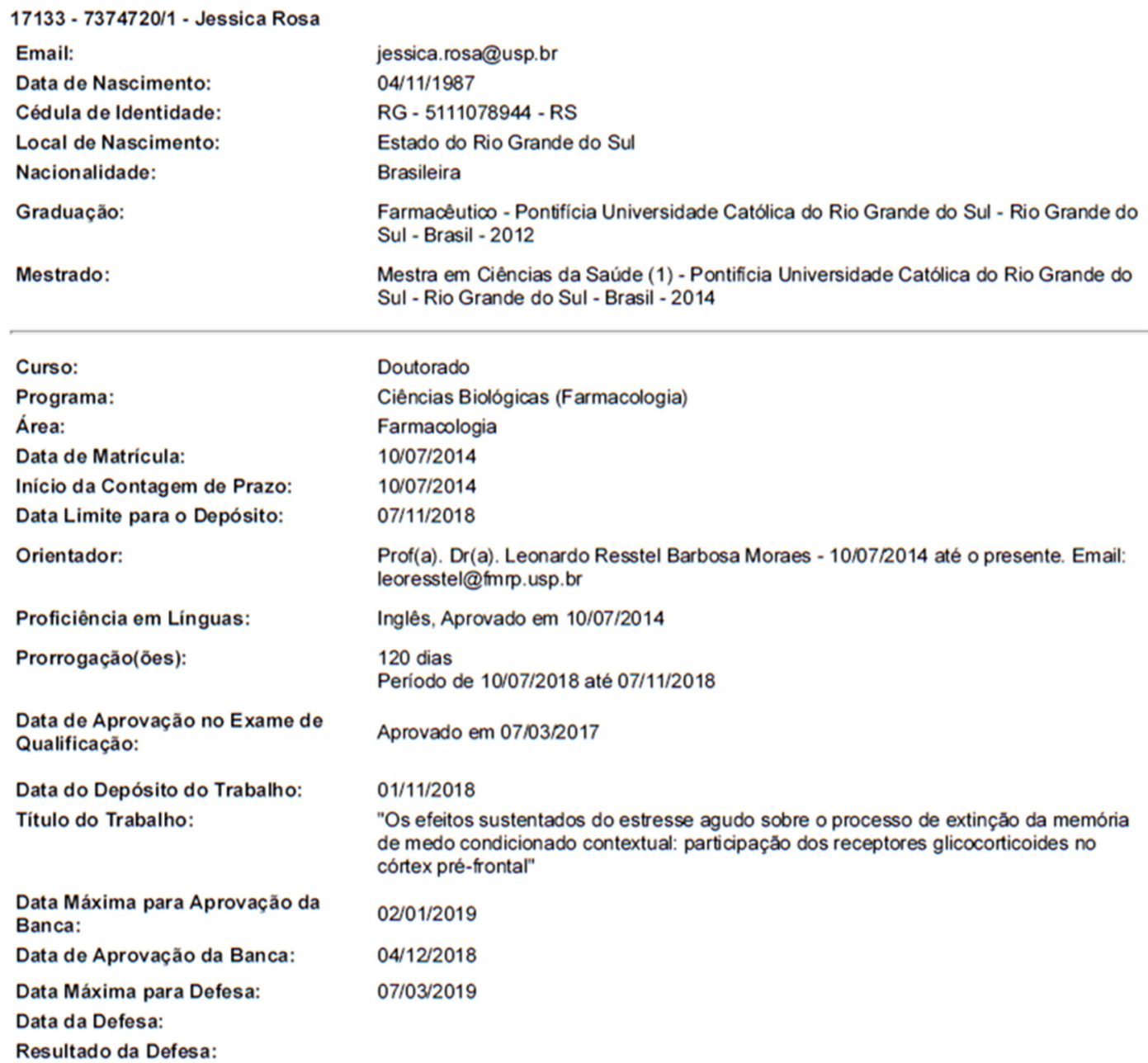

Aluno matriculado no Regimento da Pós-Graduação USP (Resolução nº 5473 em vigor de 18/09/2008 até 19/04/2013). Última ocorrência: Matrícula de Acompanhamento em 16/07/2018

Impresso em: 06/02/2019 08:25:55 
06/02/2019

Janus - Sistema Administrativo da Pós-Graduação

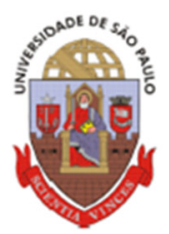

Universidade de São Paulo

Faculdade de Medicina de Ribeirão Preto

FICHA DO ALUNO

17133 - 7374720/1 - Jessica Rosa

\begin{tabular}{|c|c|c|c|c|c|c|c|c|c|}
\hline Sigla & Nome da Disciplina & Início & Término & $\begin{array}{c}\text { Carga } \\
\text { Horária }\end{array}$ & Cred. & Freq. & Conc. & Exc. & Situa ção \\
\hline $\begin{array}{c}\text { RFA5784- } \\
1 / 1\end{array}$ & Tópicos Avançados em Farmacologia II & $12 / 08 / 2014$ & $13 / 10 / 2014$ & 45 & 3 & 100 & A & $\mathrm{N}$ & Concluida \\
\hline $\begin{array}{c}\text { RFA5773- } \\
1 / 3\end{array}$ & $\begin{array}{l}\text { Farmacologia de Peptideos no Sistema } \\
\text { Cardiovascular }\end{array}$ & $08 / 09 / 2014$ & $28 / 09 / 2014$ & 45 & 3 & 100 & A & $\mathrm{N}$ & Concluida \\
\hline $\begin{array}{l}\text { RFA5741- } \\
5 / 1\end{array}$ & $\begin{array}{l}\text { Farmacologia do Controle Central da Pressão } \\
\text { Arterial }\end{array}$ & $06 / 10 / 2014$ & $19 / 10 / 2014$ & 60 & 4 & 100 & A & $\mathrm{N}$ & Concluida \\
\hline $\begin{array}{l}\text { RFA5709- } \\
6 / 1\end{array}$ & Neuropsicofarmacologia I & $09 / 03 / 2015$ & $29 / 03 / 2015$ & 75 & 5 & 100 & A & $\mathrm{N}$ & Concluida \\
\hline $\begin{array}{l}\text { RFA5758- } \\
3 / 2\end{array}$ & Interação Droga-Receptor Farmacológico & $30 / 03 / 2015$ & $03 / 05 / 2015$ & 75 & 5 & 95 & A & $\mathrm{N}$ & Concluida \\
\hline $\begin{array}{l}5925884- \\
2 / 3\end{array}$ & $\begin{array}{l}\text { Ensino Superior: Contexto, Produção de } \\
\text { Conhecimento e Docência (Faculdade de } \\
\text { Filosofia, Ciências e Letras de Ribeirăo Preto- } \\
\text { Universidade de Săo Paulo) }\end{array}$ & $15 / 09 / 2015$ & $24 / 11 / 2015$ & 60 & 4 & 80 & A & $\mathrm{N}$ & Concluida \\
\hline
\end{tabular}

\begin{tabular}{|l|c|c|c|}
\hline \hline & \multicolumn{2}{|c|}{ Créditos minimos exigidos } & Créditos obtidos \\
\hline & \multicolumn{1}{|c|}{ Para exame de qualificação } & Para de pósito de tese & \\
\hline Disciplinas: & 10 & 20 & 24 \\
\hline Estágios: & 10 & 20 & 24 \\
\hline Total: & 10 & 20 \\
\hline
\end{tabular}

Créditos Atribuídos à Tese: 152

Observações:

1) Curso com validade nacional, de acordo com o disposto na Portaria $n^{\circ} 524$, de 29.04.2008..

Conceito a partir de 02/01/1997:

A - Excelente, com direito a crédito; B - Bom, com direito a crédito; C - Regular, com direito a crédito; R - Reprovado; T Transferência.

Um(1) crédito equivale a 15 horas de atividade programada.

Última ocorrência: Matricula de Acompanhamento em 16/07/2018

Impresso em: 06/02/2019 08:25:55 
ANEXO III - Número do Processo de Bolsa de Doutorado no país, concedida pela FAPESP

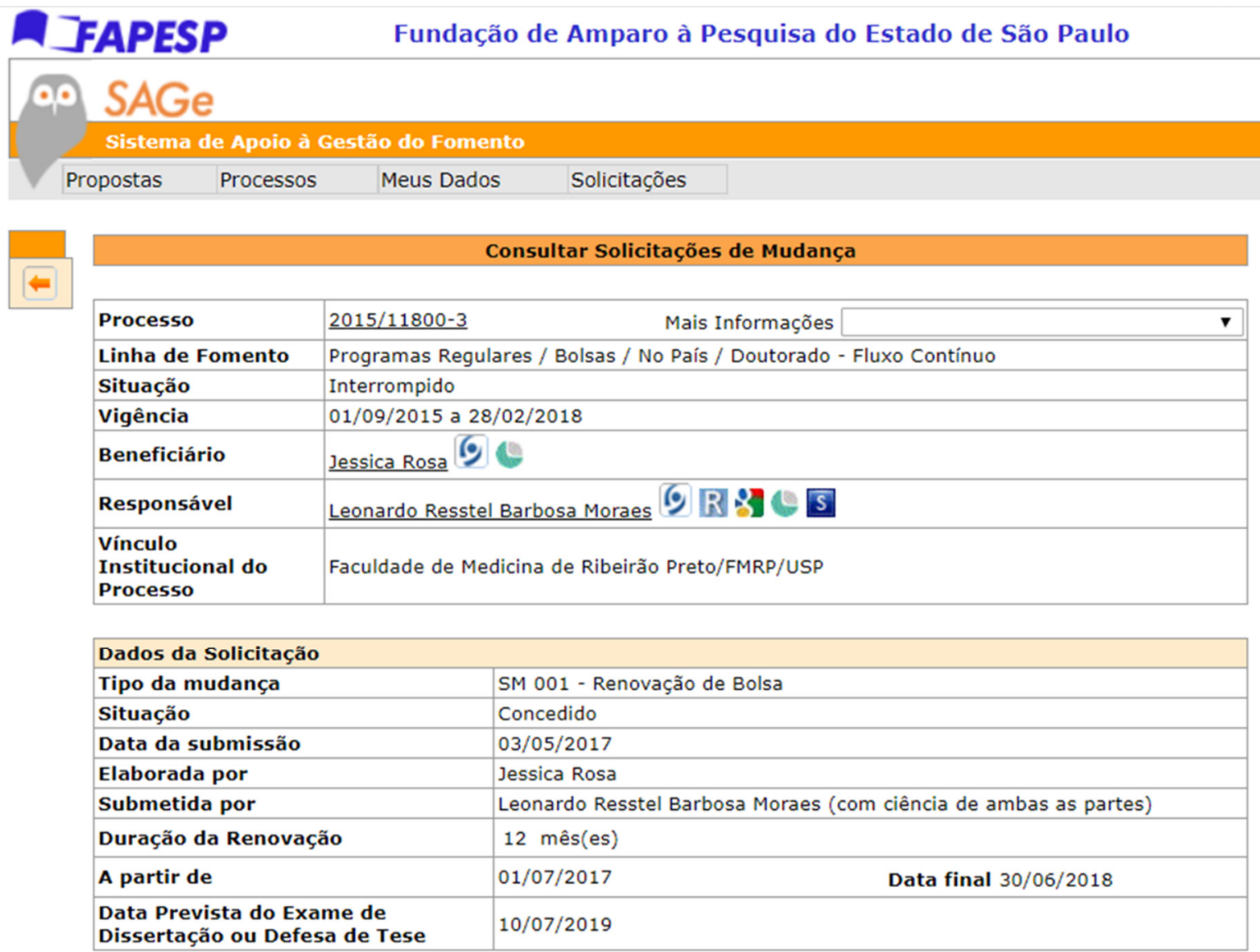




\section{ANEXO IV - Número do Processo de Bolsa de Estágio de Pesquisa no Exterior (BEPE), concedida pela FAPESP}

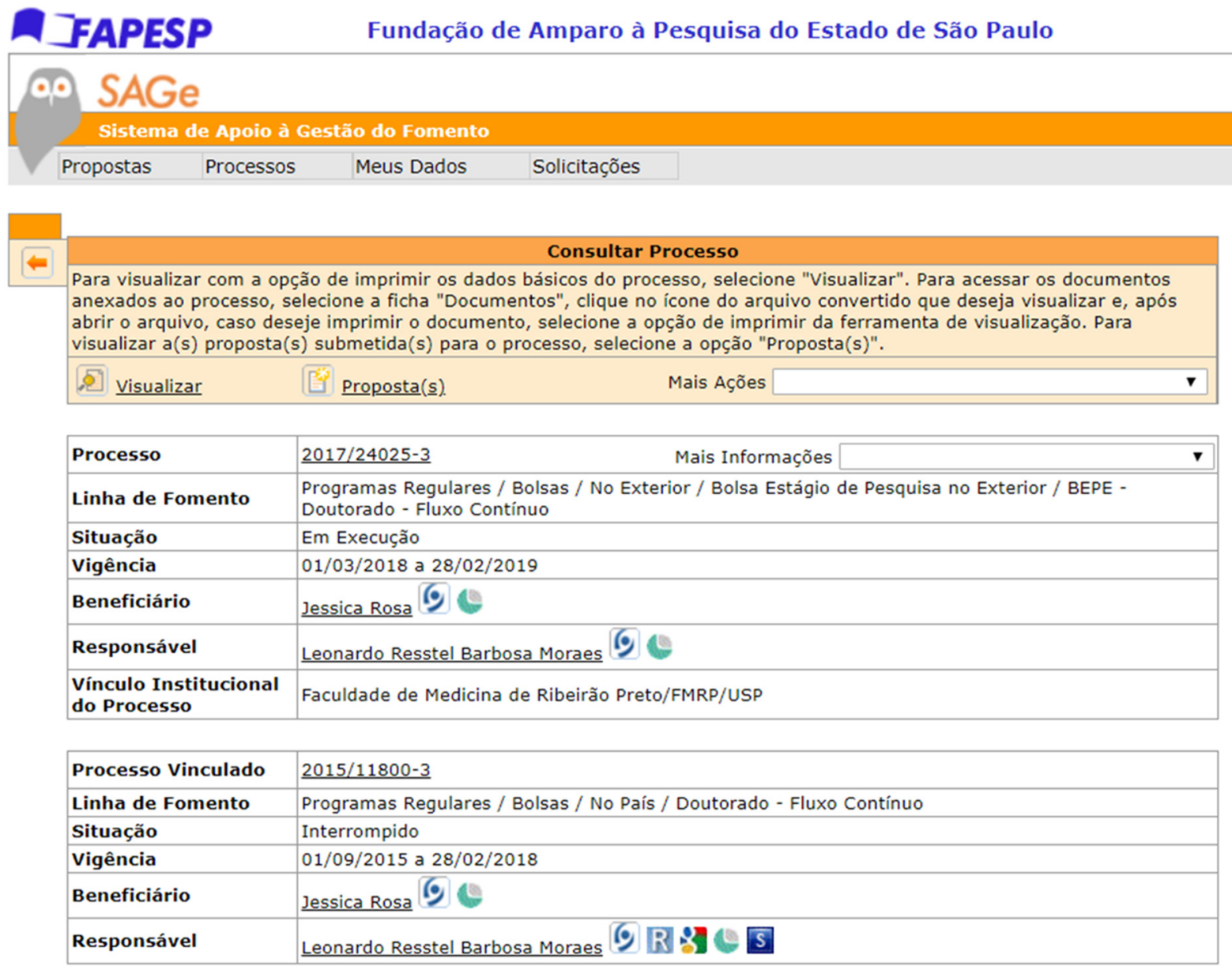


ANEXO V - Carta Justificativa para pedido de prorrogação do prazo para a defesa

Milão, 27 de janeiro de 2019.

À Comissão de Pós-Graduação da Faculdade de Medicina de Ribeirão Preto,

Eu, Jessica Rosa, CPF 060.592.479-11, aluna de Doutorado devidamente matriculada no Programa de Pós-Graduação em Farmacologia (matrícula 7374720), da Faculdade de Medicina de Ribeirão Preto, na Universidade de São Paulo (FMRP-USP), orientanda do Professor Pesquisador Dr. Leonardo Resstel Barbosa de Moraes, venho por meio desta solicitar a prorrogação da data para a defesa de minha Tese de Doutorado. O pedido de prorrogação, pelo período de 126 dias, se justifica pelos motivos seguintes:

1. Durante o $49^{\text {th }}$ Brazilian Congresso of Pharmacology and Experimental Theurapeutics, que ocorreu em outubro do ano passado (2017), ao conversar com o Professor Pesquisador Dr. Maurizio Popoli que estava presente neste evento, o mesmo aceitou-me para estágio de pesquisa em seu laboratório. Portanto, neste momento encontro-me em Milão na Itália, em meu estágio no exterior no laboratório do Professor Dr. Maurizio Popoli, e não tenho condições de defender na data máxima prevista para 04/03/2019. Fui contemplada com Bolsa Estágio de Pesquisa no Exterior (BEPE) pela Fundação de Amparo à Pesquisa do Estado de São Paulo (FAPESP). O estágio foi aprovado pela FAPESP pelo período de 1 ano, tendo início na data de 01/03/2018 e término previsto para 28/02/2019. Durante meu doutorado, fui bolsista Capes em um primeiro momento, e após Bolsista FAPESP, obtendo no total 4 anos de auxílio-bolsa no país para a conclusão de meu projeto de doutorado (somados o tempo de bolsa Capes e posteriormente FAPESP, mediante renovação de 1 ano por 
esta última agência de fomento). Além destes 4 anos de bolsa no país, a FAPESP aprovou um ano de estágio no exterior para meu doutoramento, totalizando 5 anos de bolsa-auxílio para a conclusão de meu doutoramento. Antes de aceitar a concessão da BEPE FAPESP, conversei com vários professores do departamento para expor a minha situação. Todos me apoiaram e disseram para que eu não perdesse a oportunidade do estágio. Confortaram-me dizendo que durante o estágio, veríamos como estender meus prazos para a defesa, visto que eu teria que realizar o depósito de minha "tese" ainda incompleta durante o meio do estágio fora do país, seguindo as datas do sistema Janus. O estágio no exterior tem sido uma boa oportunidade para minha carreira, e muito contribuirá para meu desempenho científico, além de nos tempos atuais ser uma avaliação importante em concursos. Estou tendo muita dificuldade de executar tarefas de meu projeto por aqui por motivos que não dependem de mim, infelizmente. E o grupo em que trabalho aqui perdeu membros importantes este ano de modo que fui colocada para trabalhar em 3 projetos do laboratório além da minha proposta de projeto para executar aqui (que segundo o grupo aqui do exterior, devem ficar em segundo plano, pois, os projetos do grupo devem ser priorizados). Deste modo, ainda estou em curso da execução experimental do meu doutorado até o meu retorno ao Brasil.

2. Além disso, ao aceitar a concessão da BEPE FAPESP, aceitei também seus termos e condições, onde preciso respeitá-los e cumprir no Brasil 4 meses de vínculo com a minha pesquisa antes de encerrá-la. Segundo o site da FAPESP (http://www.fapesp.br/6557\#4) que trata sobre a solicitações da BEPE e é de domínio público, no item 3 temos: “A solicitação de implementação da Bolsa Estágio de Pesquisa no Exterior pode ser apresentada a qualquer momento, respeitando-se a 
exigência de vínculo a Bolsas no País vigente e os prazos constantes do item 4: 4 meses para alunos de doutorado". Deste modo, após meu retorno ao Brasil, nestes 4 meses, terei condições de me dedicar a conclusão da escrita de minha tese, acrescentando os resultados que obtiver até o final de meu estágio aqui no exterior. Caso eu encerre antes do término dos 4 meses, terei que justificar também para a FAPESP os motivos. Além disso, quando de meu retorno para o Brasil, terei que me dedicar a prestação de contas (entregar os comprovantes que estão comigo aqui no exterior com justificativa) e a escrita de meu relatório da BEPE FAPESP, o qual só posso redigir quando findar as análises em meu estágio aqui no exterior, que será em meu retorno ao Brasil. E prazo para entrega-los será em 30/03/19. Além de, se eu cancelar a bolsa antes disso, em razão da minha data atual para a defesa, não terei tempo hábil para estas formalidades, e ainda, terei que finalizar a prestação de contas geral de meu doutorado, que envolve o processo de patrimônio dos bens materiais comprados com a verba de pesquisa vinculada a minha bolsa, bem como o relatório final juntamente com meus compromissos da BEPE.

3. Há também a questão pessoal. Devido ao extensivo trabalho em meu estágio no exterior, ainda não submeti nenhuma proposta para concorrer a uma bolsa de pósdoutorado, e não terei como dedicar tempo a isto neste momento. De modo que, antecipando o cancelamento de minha de doutorado no Brasil (que está vigente até 30/06/19 pela FAPESP), pelo motivo de minha data de defesa prevista para agora em março, estarei desempregada. Se eu estivesse no Brasil neste momento, sendo graduada em Farmácia e com experiência de trabalho na área, já estaria providenciando minha documentação junto ao Conselho Regional de Farmácia, para poder trabalhar, enquanto aguardaria uma oportunidade de estágio de pós- 
doutoramento. Mas estando em outro país, nem esta documentação consigo providenciar agora, o que farei quando de meu retorno. E ainda, quando de meu retorno ao Brasil, precisarei pensar em minha acomodação, pois, sou natural do Rio grande do Sul e todos os meus familiares e amigos próximos estão no Sul do país, e não tenho uma acomodação para ficar quando eu retornar ao país. Vou ficar na casa de amigos em Ribeirão Preto inicialmente, para poder me organizar neste aspecto já nas primeiras semanas de meu retorno.

Ciente de que a Universidade de São Paulo, no que diz respeito ao prazo para conclusão para o curso de doutorado, estipula o prazo de 60 meses para alunos de doutorado portadores do título de mestre - Sessão III, Artigo $43 \S 3^{\circ}$ da Resolução Nº 7493, de 27 de Março de 2018, minha solicitação para prorrogação de meu prazo de defesa em 126 dias não fere esta resolução de nossa instituição. Saliento novamente a importância da prorrogação do prazo para defesa de minha Tese, pois, estou no atual momento em meu estágio de pesquisa no exterior, em fase de conclusão das análises executadas por aqui, e sem condições de em meu retorno, imediatamente defender meu doutorado. A prorrogação da data de minha defesa pelo período solicitado, será de suma importância para que eu possa cumprir as formalidades pertinentes aos meus compromissos com a FAPESP, com meu projeto, e para com o meu orientador e seu laboratório no Brasil, além de concluir adequadamente minhas funções no laboratório aqui no exterior. Não menos importante, para que eu possa ter um momento de real dedicação à conclusão de minha Tese e aos preparatórios da impressão da mesma junto à gráfica para o envio aos membros da banca. Para que assim, minha defesa de doutorado seja realmente satisfatória e reflexo de toda a minha dedicação e empenho durante este período de doutoramento nesta instituição. 
Agradeço a possível compreensão de meu caso, e esperando merecer sempre as melhores atenções desta Comissão para o que solicito, subscrevo-me.

Jessica Rosa

Prof. Dr. Leonardo Resstel Barbosa de Moraes 
ANEXO VI - Formulário de solicitação de aluno para prorrogação do prazo para a defesa

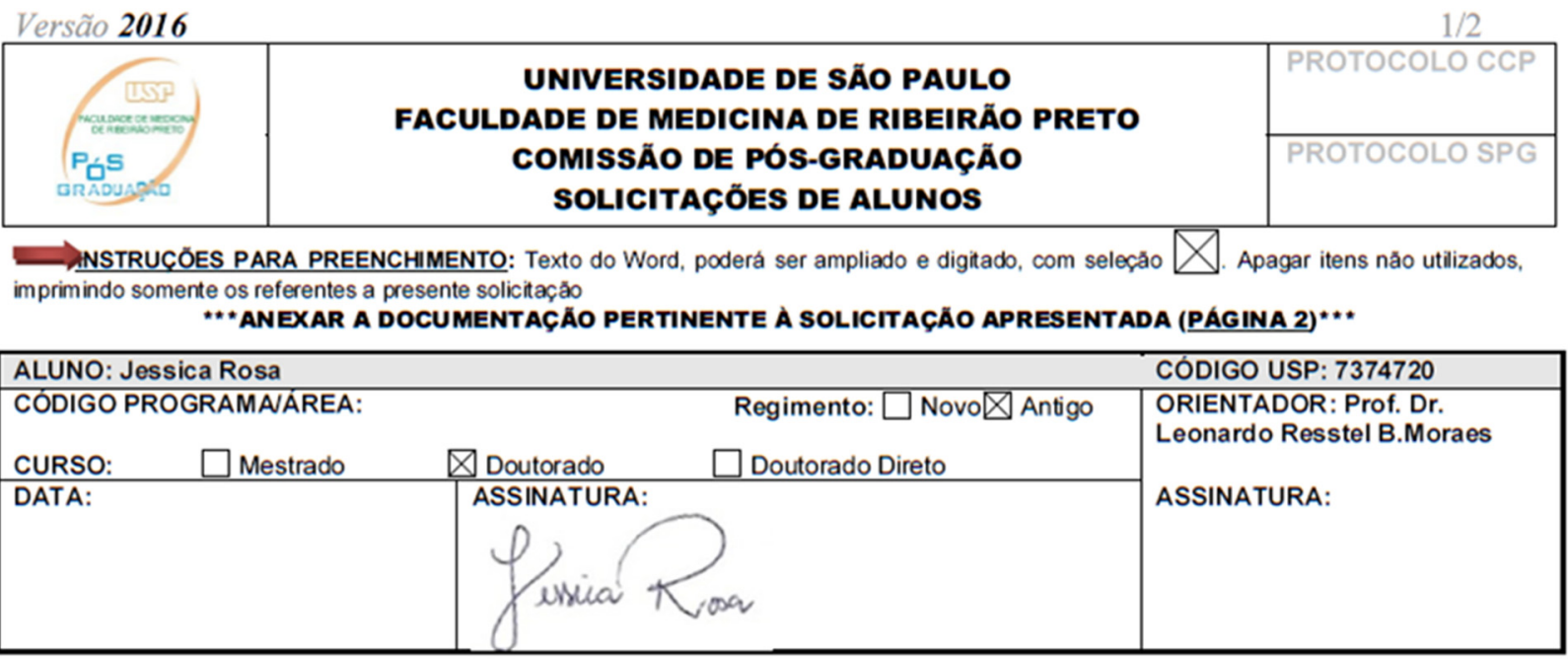

PARA ANÁLISE DA COMISSÃO COORDENADORA DO PROGRAMA (CCP):

I. ATRIBUIÇÃO DE CRÉDITOS

$\square$ 1. Disciplina(s) cursada(s) no Mestrado, disponiveis $\mathrm{p} /$ Doutorado Código(s):

$\square$ 2. Disciplina(s) cursada(s) como Aluno Especial Código(s):

PARA ANALISE DA CCP e DA CPG:

\section{ALTERAÇŌES DE VÍNCULO OU PRAZOS}

\9. Prorrogaçăo de prazo para defesa (Prazo: 126 dias)

\begin{tabular}{|c|c|c|}
\hline $\begin{array}{c}\text { Para utilizacão } \\
\text { Conforme Regimento de Pós-Graduaçăo da }\end{array}$ & $\begin{array}{l}\text { da COMISSĀO COORL } \\
\text { ISP (artigo___ e a }\end{array}$ & $\begin{array}{l}\text { DENADORA DO PROGRAMA (CCP) } \\
\text { s normas do Programa (item }\end{array}$ \\
\hline $\begin{array}{l}\text { DDEFERIDO: } \square \text { CCP } \square \text { Coordenador “Ad } \\
\text { Créditos concedidos: } \\
\text { Com ressalvas: } \\
\text { DINDEFERIDO }\end{array}$ & $\begin{array}{l}\text { ferendum" da CCP } \\
\text { oncedido: } \_ \text {dias }\end{array}$ & $\begin{array}{l}\text { PROVIDÉNCIAS: } \\
\text { Lancado no JANUS em } \\
\square \text { Aos interessados, para ciência. } \\
\square A \text { CPG, para providéncias. }\end{array}$ \\
\hline $\begin{array}{l}\text { Data da Reuniăo da CCP ou do "Ad Referendum" } \\
\text { do Coordenador: }\end{array}$ & Assinatura e carimbo & do Coordenador da CCP: \\
\hline Para util & ação da COMISSĀO & DE PÓS-GRADUAÇĀO (CPG) \\
\hline $\begin{array}{l}\text { DEFERIDO: } \square \text { CPG } \square \text { Presidente "Ad Ret } \\
\text { Créditos concedidos: } \\
\text { Com ressalvas: } \\
\square \text { INDEFERIDO }\end{array}$ & $\begin{array}{l}\text { rendum" da CPG } \\
\text { oncedido: } \_ \text {dias }\end{array}$ & 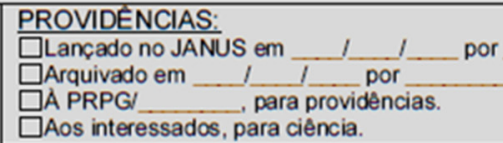 \\
\hline $\begin{array}{l}\text { Data da Reuniâo da CPG ou do "Ad Referendum" } \\
\text { do Presidente: }\end{array}$ & Assinatura e carimbo & do Presidente da CPG: \\
\hline
\end{tabular}


TODAS as solicitações devem vir acompanhadas da FICHA DO ALUNO atual (www.sistemas.usp.br/janus)

\section{Para Análise da COMISSĀO COORDENADORA DO PROGRAMA: \\ I. ATRIBUIÇÃO DE CRÉDITOS}

1. Disciplinas Cursadas no Mestrado disponiveis para o Doutorado: a) código das disciplinas:

b) ficha do aluno (do Mestrado)

2. Disciplinas Cursadas como aluno Especial:

a) código das disciplinas:

b) ficha do aluno (como especial).

II. ALTERAÇÖES DE VÍNCULO OU PRAZOS

1. Inscriçăo no Exame de Qualificaçăo (nenhum documento)

\section{ATRIBUIÇÃO DE CRÉDITOS}

\section{Para Análise da CCP e da CPG:}

1. Crédítos Especiais (verificar opçáo de RE GIMENTO do aluno)

Participaçăo em Congresso com publicaçăo de Trabalho:

a) Cópia do Resumo/Trabalho publicado onde conste o número da página e volume, (ou a informaçăo de publicacăo através de $C D$ ROM ou ON LINE);

b) Titulo do Trabalho em Portugues:

c) Cópia da Capa do Anais/Revista onde foi publicado o trabalho, com o nome da cidade e pais de publicacăo:

d) Cópia do Comprovante de participaçăo do aluno no evento:

e) Título do Projeto de Dissertaçă/Tese.

f) Formulário para solicitação de créditos especiais.

Trabalho Completo, Capitulo De Livro, Capltulo De Manual:

a) Cópia do Trabalho publicado onde conste o número da página e volume, (ou a informaçăo de publicaçăo digital= DOI), data e local (cidade e país) da publicaçăo:

b) Titulo do Trabalho em Portuquês:

c) Cópia da Capa do Anais/Livro/Manual, onde foi publicado o trabalho: d) Título do Projeto de Dissertaçăo/Tese.

e) Formulário para solicitaçăo de créditos es peciais.

Atividades programadas:

a) declaraçao comprovando o atendimento a pacientes no suS no PAE semestre.

a) cópia do comprovante (certificado/declaraçăo) de conclusăo.

Deposito de PATENTES:

a) Documento Comprobatório do Registro.

2. Disciplinas cursadas em outra instituiçấ:

a) declaração constando nome da disciplina, nome do Programa de Pós-Graduaçăo e da Universidade, periodo (data de inicio e de têrmino), frequência, conceito:

b) programa e carqa horária da disciplina/curso:

c) comprovante do Reconhecimento do Curso (MEC/CAPES)

3. Equivaléncia de Titulo de Mestre $\rho /$ contagem de créditos para o doutorado:

a) cópia do Histórico Escolar do Mestrado

b) cópia do Diploma do Mestrado, com número de Registro:

c) comprovante do Reconhecimento do curso (MEC/CAPES), no período da conclusăo.

\section{ALTERAÇÕES DE VÍNCULO OU PRAZOS}

1. Cancelamento de Matricula em disciplina (fora de prazo)

a) formulárid/comprovante on-line de cancelamento

b) carta do aluno de justificativa com concordáncia do orientador e do responsável pela disciplina.

2. Conceito e frequencia:

a) justificativa do docente responsável pela disciplina constando conceito(s) e frequência(s) do(s) aluno(s);

b) listas de presenca.

3. Dupla titulaçáo:

a) Oficio de encaminhamento da Coordenaçăo do Programa com aprovaçăo da Comissăo Coordenadora do Programa à Comissão CPG;

b) Carta de justificativa e aceitaçăo do orientador da USP (informar se existe solicitaçăo ou aprovaçăo de auxilio/bolsa de aqências de fomento);

c) Auxilio de agências de fomento (documentaçáo comprobatória de aprovaçăo de solicitaçăo, se houver);

d) Plano de pesquisa;

e) Carta de aceitaçăo do orientador estrangeiro;

f) Curriculo do orientador estrangeiro;

g) Cópia impressa e por e-mail speâfmrn.usp.br da minuta de convênio, aceita pela IES estrangeira, em português e na lingua estrangeira.
4. Desfigamento do Programa:

a) Preencher somente justificativa do aluno (motivo) no anverso. 5. Depósito de Dissertaçã ITese

a) título informado neste formulário năo poderá sofrer alteraçōes posteriores

b) obrigatório assinalar a aptidăo do trabalho (dissertaçăo, tese, etc)

b) ficha do aluno (impressa pelo janus)

c) cópia da banca indicada (impressa pelo ProBancas);

d) termo de ciência e concordância (nâo é permitida assinatura digitalizada)

6. Nova Matricula

a) justificativa do interessado (por qual motivo foi desligado Art 54):

b) anuência do orientador:

c) plano de trabalho aprovado pelo orientador;

d) histórico escolar do antigo curso;

e) manifestaçăo da CCP apoiada em parecer circunstanciado, emitido por um relator por ela desianado.

7. Matricula em Disciplina Fora de Prazo (após término da turma) a) formulário/comprovante on-line de matrícula

b) carta do aluno de justificativa com concordância do orientador;

c) carta do responsável pela disciplina constando conceito e frequencia;

d) listas de presença constando assinatura do aluno, œnforme frequéncia.

8. Prorrogaçâo de prazo para Depósito

a) justificativa do aluno com parecer circunstanciado do orientador (Motivo);

b) versăo preliminar da dissertaçăo/tese com atividades e resultados obtidos até omomento;

c) cronograma indicativo das atividades a serem desenvolvidas no periodo.

9. Promrogaçấo de prazo para Defesa

a) justificativa detalhada, indicaçăo da comissăo julgadora e prazo pretendido assinada pelo aluno e orientador (Motivo);

b) em caso de doenca, atestado médico emitido ou validado pelo SISUSP, onde conste a dœenca (CID), o periodo necessário para tratamento e data de inicio do tratamento;

c) outros motivos: comprovantes de acordo com a justificativa.

OBS.: se houver substituiçăo de membros da banca, a documentaçăo de desistência deverá ser encaminhada.

10.Trancamento de Matrícula

OBS.: BOLSAS CAPES DEVERÃO SER SUSPENSAS

DOENÇ:

a) Formulário PRPG (unw. fmro.usp. bricpg - formulários).

b) atestado médico expedido ou validado pelo SISUSP, onde conste

a doenca (CID), o periodo necessário para tratamento e data de inicio

do tratamento;

c) parecer circunstanciado do orientador.

TRABALHO:

a) Formulário PRPG (unw. fmro.usp.br/cpg - formulários)

b) comprovante que justifique 0 afastamento (diário oficial, etc):

c) documento que comprove que a empresa/instituiçăo dispensará o aluno, após período de trancamento, para assumir novamente as atividades da $\mathrm{P}$ ós-Graduaçăo;

d) parecer circunstanciado do orientador

LICENCAA MATERNIDADE:

a) certidão de nascimento

11. Transferéncia do Mestrado para Doutorado

a) parecer do Programa de acordo com as normas da CCP, previamente aprovados pela CPG e CoPGr.

12. Transferéncia de Área/Programa

a) justificativa circunstanciada do interessado:

b) concordância manifestaçăo do novo e do atual orientador(es);

c) concordância das CCPs dos Programas envolvidos:

d) histórico escolar completo do curso iniciado anteriormente;

e) parecer da CPG anterior, se houver, sobre o desempenho do aluno.

13. Reintegração na Pós-Graduaçăo:

a) carta do aluno/orientador/coordenador do programa constando justificativa. Comprovantes da justificativa.

14. Mudança de orientador (COM concordancia).

a) se o proieto for novo acrescentar o título. Mudanca de Orientador (SEM concordância)

a) iustificativa circunstanciada do solicitante;

b) parecer da CCP:

c) Cópia do NOVO projeto, quando for o caso.

\section{Outra Solicitaçâo: CONSULTAR SECRETARIA DO PROGRAMA} OBSERVACOES: 
ANEXO VII - Parecer as Secretária de Pós-Graduação da FMRP-USP

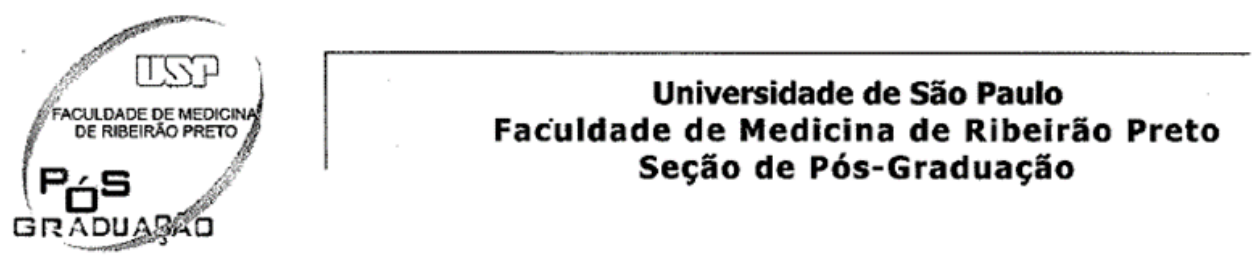

Data: 06/02/2018

DEVOLUCÃO DE DOCUMENTOS AO PROGRAMA DE PÓS-GRADUACÃO: FARMACOLOGIA

A/C: GISLAINE

DOCUMENTO: Solicitação de prorrogação de prazo para defesa da aluna Jéssica Rosa.

MOTIVO DA DEVOLUÇĀO: Após análise do Prof. Ricardo Cavalli, constatou-se que a justificativa apresentada para a solicitação não é cabível para tal pedido.

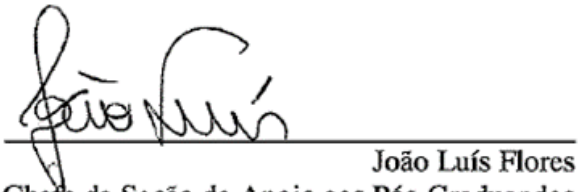

Chete da Seção de Apoio aos Pós-Graduandos

FMRP/USP 
ANEXO VIII - Cancelamento da Bolsa FAPESP (Bolsa no país)

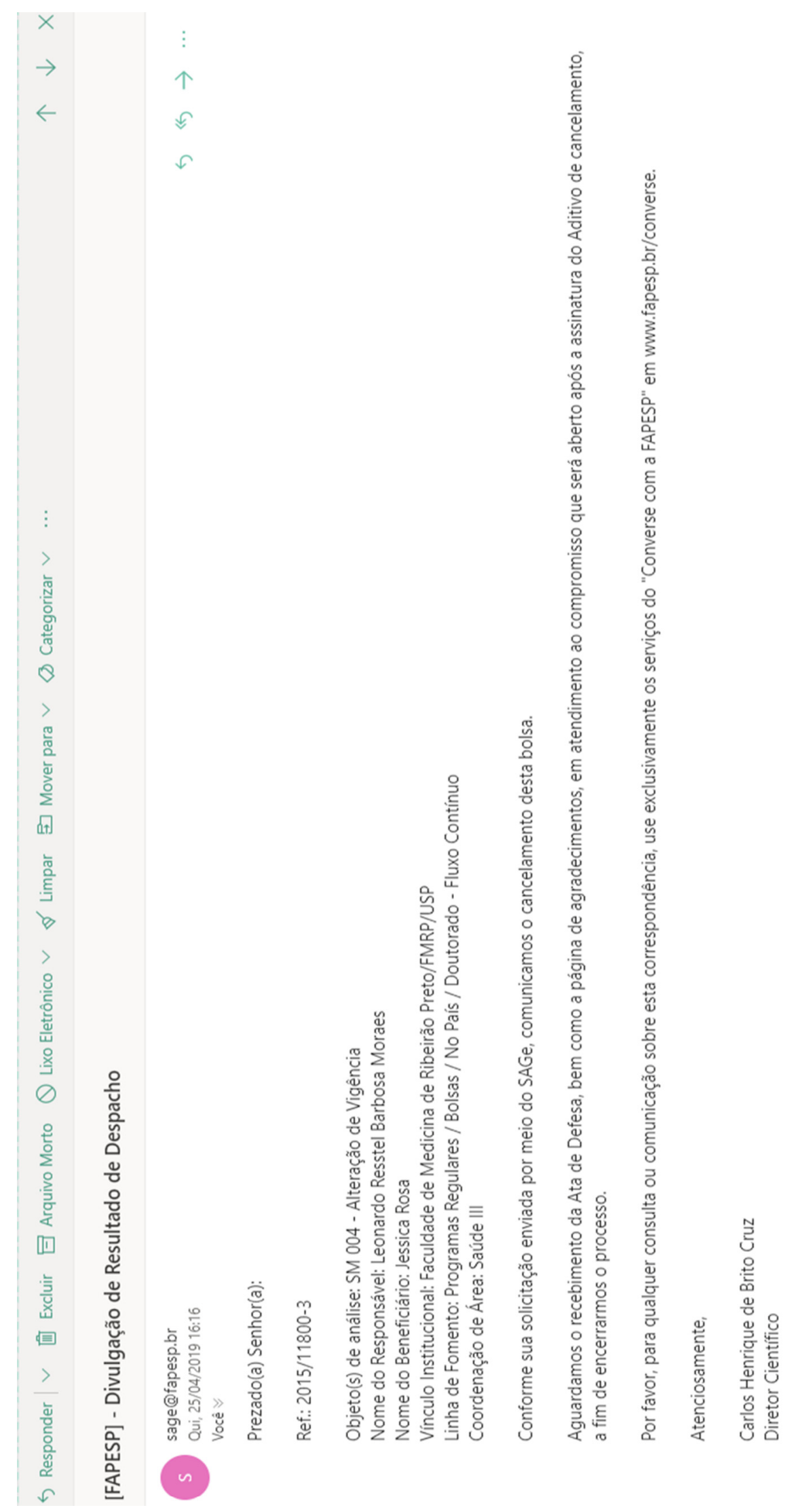




\section{ANEXO IX - Carta de aceite do supervisor no exterior durante o período da BEPE FAPESP}

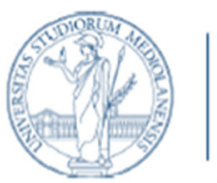

UNIVERSITÀ DEGLI STUDI DI MILANO

DIPARTIMENTO DI SCIENZE FARMACOLOGICHF

E BIOMOLECOLARI - DiSFeB

Prof. Maurizio Popoli

Milan, November 132017

Re.: Declaration for Jessica Rosa

To Whom It May Concern:

Miss Jessica Rosa, MSc, is graduate student at Ribeirão Preto Medical School, University of São Paulo. She has applied for visiting student position in my laboratory at Department of Pharmacological and Biomolecular Sciences, University of Milano (UNIMI), Italy, between February 1st, 2018 and February 1st, 2019. For her studentship project, she has proposed to work on a project titled: "The long-term effects of acute stress in the prefrontal cortex on the fear extinction memory". This project is very interesting and suitable to be conducted in my laboratory. I therefore am happy to accept this project of the visiting student Miss Jessica Rosa for your PhD internship on abroad. I would also be happy to evaluate her performance and report concerning to this project.

If there are any questions concerning this matter, please do not hesitate to contact me about it.

Yours sincerely,

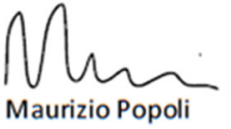




\section{ANEXO $\mathbf{X}$ - Projeto BEPE FAPESP}

\section{PLAN OF ACTIVITIES}

PhD. Candidate: Jessica Rosa, MSc.

Propose: PhD. visiting student (PhD. internship) - Period Sandwich: $1^{\text {st }}$ March 2018 to $1^{\text {st }}$ March 2019 (12 months).

Supervisor in Brazil (University of São Paulo): Leonardo B. M. Resstel, PhD. Supervisor in Italy (University of Milan): Maurizio Popoli, $\mathrm{PhD}$.

PhD. PROJECT TITLE: The long-term effects of acute stress in the prefrontal cortex on the fear extinction memory

\section{I) INTRODUCTION}

The memory, from the neurobiological perspective, refers to the ability to remember (recall/retrieval) a previously acquired (learned) experiences and knowledge which were stored (consolidated) (Izquierdo, 2002; Kolb et al., 2016). And the retrieval of previously consolidated memory can lead to its extinction. The learning of extinction has an enormous physiological and/or adaptive importance and is used in the psychotherapy for treatment of phobias or posttraumatic stress disorder (PTSD), under the name of exposure therapy (Asukai, 2013; Brewin and Holmes, 2003; Furini et al., 2013; Morrison and Ressler, 2014; VanElzakker et al., 2014). It consists of the learned inhibition of retrieval of a previously acquired memory (Fiorenza et al., 2011, 2012; Furini et al., 2013).

To study of fear memory extinction, the contextual fear conditioning (CFC) is widely used (Domingos et al., 2017; Fiorenza et al., 2012; Fitzgerald et al., 2013; Izquierdo, 2006; Schiller et al., 2013), because it is a great test that provides an interface between memory and emotion (Bentz et al., 2013; LeDoux, 2000). In this behavioral procedure, the animal learns that an environmental stimulus, such as a context, can predict an aversive stimulus such as electric footshocks. Thus, occurs an association of the environment (neutral/conditioned stimulus) to the electrical stimulus (aversive/unconditioned stimulus). Once re-exposed to the context in which the conditioned-unconditioned stimulus association was performed, the animal does not have the possibility of escape, and then emits a conditioned emotional response, which involves the innate behavioral parameter called freezing (total immobility of the animal, except breathing 
movements) (Fiorenza et al., 2012; Izquierdo, 2006; Izquierdo et al., 2016; Maren et al., 2013), as well an increase of the mean arterial blood pressure (BP) and heart rate (HR), and decrease of the cutaneous temperature (CT) (Hott et al., 2017; Spiacci et al., 2016; Uliana et al., 2016). The later re-exposure of the animal to the context in the absence of the aversive/unconditioned stimulus produces a gradual decrease in conditioned emotional response, which the learning of extinction is observed (Furini et al., 2013; Mueller and Cahill, 2010; Orsini and Maren, 2012; Rescorla, 2004; Singewald et al., 2014; VanElzakker et al., 2014).

Because it is a new learning, extinction memory needs to be acquired and consolidated, it requires the activation of cellular and molecular mechanisms in several regions of the brain (Berlau and Mcgaugh, 2006; Wichert et al., 2013) such as the prefrontal cortex (PFC) (Berlau and Mcgaugh, 2006; Fiorenza et al., 2012; Kaplan and Moore, 2011; Orsini and Maren, 2012). The PFC is a limbic structure that performs executive functions and regulates emotions and behavior (Lu and Richardson, 2014, 2014, McKlveen et al., 2013, 2013; Popoli et al., 2012). In humans and rodents, the ventromedial portion of PFC (VmPFC) has been considered as a critical site for the control of the conditioning fear extinction (Fiorenza et al., 2012; Lonsdorf et al., 2014; Popoli et al., 2012; Raio et al., 2014). In rodents this structure is subdivided into two regions: prelimbic (PL), which seems to be essential for the storage and expression of conditioned fear (Fukushima et al., 2014), and the infralimbic region (IL, comparable to human vmPFC) (Milad and Quirk, 2012; Singewald et al., 2014) which plays an important role in the acquisition and consolidation of extinction and its recall (Knox et al., 2012; Maren et al., 2013).

It is observed a deficit in the recall of extinction memory and a decrease in the density of dendritic spines in the PFC due to the exposure of individuals to chronic stress (McKlveen et al., 2013; Moench and Wellman, 2014), evidencing the role of PFC in the modulation of stress responses. However, the effects of acute stress on extinction performance and its consequences on dendritic spine density in PFC needs more investigation, mainly about the long-term outcome of acute stress. The PFC makes connections with other brain structures related to extinction. Projections of PL seems to establish the connection with the basal and central nucleus of the amygdala, while the IL maintains connections with almost all of the amygdaloid complex. However, PL and IL receive basolateral amygdala projections (Hübner et al., 2014; Milad and Quirk, 2012; Singewald et al., 2014), and both regions process memories for negative events and control the magnitude of psychological responses to adversity, including the release of stress hormones, such as glucocorticoids (McKlveen et al., 2013; Moench and Wellman, 2014). 
Cortisol, a glucocorticoid hormone in humans, and corticosterone in rodents (Myers et al., 2014), after released in the systemic circulation, cross the blood-brain barrier and their biological effects occurs by binding to mineralocorticoid receptors (MRs), at basal conditions, and glucocorticoid receptors (GRs), during the peak of the circadian cycle of this hormone, or under stress conditions (Kolber et al., 2008; Myers et al., 2014; Roesler and Schröder, 2011; Solomon et al., 2014). Appropriate signaling of these receptors in different brain regions is critical for hypothalamic-pituitary-adrenal (HPA) axis regulation, control of emotional responses and cognitive performance (Klok et al., 2011). And alterations in the expression/activity of the mineralocorticoid and glucocorticoid receptors may contribute to the development of psychiatric illness in predisposed individuals (van Haarst et al., 1997; Han et al., 2014; de Kloet, 2000, 2014; Klok et al., 2011; Kolber et al., 2008; Qi et al., 2013; Xing et al., 2004).

In the current scientific literature, it has been proposed that a brief exposure to stress leads to deficits in extinction fear memory and increases glutamate release in the vmPFC, which is an important site involved in cardiovascular, neuroendocrine and behavioral responses (Cahill and McGaugh, 1996; Ferreira-Junior et al., 2013; Izquierdo, 2006; Lemos et al., 2010; Lisboa et al., 2010; Mueller et al., 2008; Musazzi et al., 2017; Pizzorusso, 2009; Popoli et al., 2012; Resstel and Corrêa, 2006; Santini, 2004; Treccani et al., 2014). Moreover, there is a high expression of GRs and MRs in this brain structure. (McKlveen et al., 2013; Mizoguchi et al., 2009). In our previous results, we demonstrated that the stressed animals have an increase in the expression of contextual fear conditioning. Both groups, underwent an acute stress or control manipulation, extinguished fear responses over the time during extinction session. However, one day later, the stress group demonstrated significantly less extinction retrieval than control (not stressed group). This suggests that the acute stress did not impair the acquisition, but promoted a deficit in the consolidation of extinction fear memory. In addition, this effect is variable according to the time of exposure to the stressor event, the time interval between the stressor event and the aversive conditioning, and the intensity of the aversive stimulus. These findings are in agreement with several scientific publications that point out that the exposure to stress before trauma can be a risk factor for the development of psychopathological disorders (Asukai, 2013; Gourley et al., 2009; Kolber et al., 2008; Musazzi et al., 2017). Interestingly, the GRs antagonist (RU 486; 10ng/side) microinjected into the PL or IL, immediately after the extinction session, attenuated the deficit promotes by restraint stress, but the MRs (RU 28318) at a dose of 150ng/100nl/side didn't attenuate such deficit in stressed animals. In a partial conclusion, our results reveal that a brief and single episode of 
stress induced before a training of CFC leads to extinction deficit. Together, our data demonstrated that the glucocorticoid receptors are necessary in PL and IL regions of the vmPFC for the establishment of extinction deficit promoted by acute stress. It is important to characterizing how stress affects the extinction memory and can offer new insights about the extinction-based exposure therapy.

Post mortem clinical studies have suggested that alterations in GRs and/or MRs expression are associated with the development of psychiatric disorders (van Haarst et al., 1997; Han et al., 2014; de Kloet, 2000, 2014; Klok et al., 2011; Kolber et al., 2008; Qi et al., 2013; Xing et al., 2004), and at the moment, we are conducting analyzes to evaluated if there is alteration in the expression of these receptors in the vmPFC of the animals submitted to our behavioral protocol.

The glucocorticoids effects on memory follow an inverted "U" curve. Thus, it effects on cognitive performance dependent on its circulating concentrations and its occupation of the MRs and GRs (Izquierdo et al., 2016; Kolber et al., 2008; Lass-Hennemann and Michael, 2014; McKlveen et al., 2013; Popoli et al., 2012). Therefore, the effect on consolidation of fear extinction, but not in its acquisition, may be due to a change in the expression/activity of these receptors for glucocorticoid hormones promotes by acute stress. Also, due to the impact of level of stress hormone influencing on the cognitive performance of the animals. In the latter case, the stressed animals can be sensitized or hyper-responsive to the aversive stimulus, and when exposed to the task in the extinction session, show the rapid increase of corticosterone, which may increase the expression of the conditioning emotional response associated with fear memory. And the extinction performed in the presence of very high levels of such hormone can impair the consolidation of the extinction memory maybe be influencing the glutamatergic transmission and plasticity. This idea is supporting by recent findings, in animal model, that proposed that the acute stress can produce a sustained enhancement of glutamate release in PFC. This mechanism appears to be dependent on elevation of the stress hormone corticosterone, which leads to retraction of apical dendrites and this effect is sustained for up to 14 days (Musazzi et al., 2017). However, we need conducting further molecular and morphological experiments to confirm this supposition. Our hypothesis is that MRs and GRs can modulate the fear extinction memory in rodents submitted to acute stress, and such stress promotes deficit in the contextual fear extinction through the long-term alterations in the expression of the GRs and MRs in the vmPFC, which results in abnormal glutamatergic transmission, as well the morphological changes in this brain area. 


\section{SPECIFIC GOALS (SG):}

SG 1 - Evaluation of the long-term effect of acute stress on dendritic morphology of pyramidal neurons in the PL and IL regions of the vmPFC, after extinction session of the CFC protocol.

SG 2 - Evaluation of the long-term effect of acute stress on the glutamatergic transmission in the vmPFC, after extinction session of the CFC protocol.

\section{METHODS}

3.1. Golgi-Cox staining: To evaluation of the long-term effect of acute stress on dendritic morphology of pyramidal neurons in the PL and IL regions of the vmPFC, after extinction session of the CFC protocol, brain samples will be collected in Brazil (Neuropharmacology Laboratory, School of Medicine, Pharmacology Department, University of São Paulo, Ribeirão Preto) and will be shipped to Italy (Laboratory of Neuropsychopharmacology and Functional Neurogenomics, Department of Pharmacological and Biomolecular Sciences University of Milano). To the brain sample collection, animals will be submitted to the extinction of CFC procedure, that will be realized in Brazil, which it was approved by an Animal Ethics Committee yet (CEUA-FMRP/USP 69/2015). The design of CFC protocol is the same that will be described in the next method of this project (see details below in Figure 1). After the extinction session, the animals will be sacrificed, and the brain removes and quickly store at $80^{\circ} \mathrm{C}$. In Milan, to the analysis of the morphology and density of dendritic spines of the neurons in the PL and IL regions of the vmPFC, the brains sample from Brazil of the animals under stressed, non-stressed and naive conditions will be processed. To this, the samples will be exposed to Golgi-Cox impregnation solution, following sectioning, slide preparation and staining procedure. Finally, the application of confocal microscopy will be performed (Leuner and Gould, 2010).

3.2. Synaptosomes: To evaluation of the long-term effect of acute stress on the glutamatergic transmission in the vmPFC after extinction session of the CFC protocol, design experimental involving animals will be performed. It will be made in accordance with the European Community Council Directive 86/609/EEC, and will be submitted to Italian legislation on animal experimentation. To the behavioral procedure, adult Sprague-Dawley male rats will be maintained in home cages with free access to food and water, and will be divided in two groups: 1) Stressed group (restraint stress for 1 hour); 2) Control group (without restraint stress). On 
the 7th day, both groups will be exposed to the extinction of contextual fear conditioning protocol: Training (four footshocks $0,85 \mathrm{~mA}$ for $1 \mathrm{sec}$ ), followed by extinction $(20 \mathrm{~min}$ ) and extinction retention sessions ( $5 \mathrm{~min}$ ). All sessions with a 24-hour interval. Freezing behavior will be measured in all sessions by a chronometer and will be taken as an indicator of memory. Details of experimental protocol are demonstrated in the following figure:

1

The animals were divided in two groups: 1) Stressed group -restraint stress (RE) for $1 \mathrm{~h}$;

2) Control group -without restraint stress.

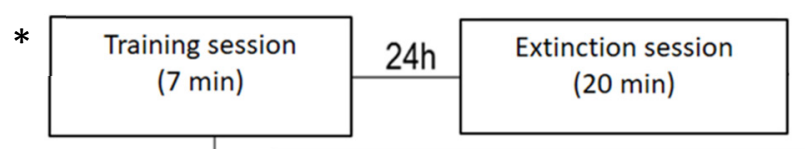

After extinction session:

Animals will be sacrificed and their brains removed to analysis

2 min of habituation; Four randomic electric footshocks $(0.85 \mathrm{~mA} / 1 \mathrm{~s}) ; 2$ min without shocks.

Figure 1. Behavioral design.

The animals under the stressed, non-stressed and naive conditions will be decapitated and the brains removed and vmPFC immediately dissected on ice. The in vivo synaptosomes will be performed in accordance with the Ryan and collaborators (Ryan et al., 2009).

\section{CHRONOGRAM}

\begin{tabular}{|c|c|c|c|c|c|c|c|c|c|c|c|c|}
\hline Specific Goals (SG) & $\begin{array}{c}\text { Month } \\
1\end{array}$ & $\begin{array}{l}\text { Month } \\
2\end{array}$ & $\begin{array}{l}\text { Month } \\
3\end{array}$ & $\begin{array}{l}\text { Month } \\
4\end{array}$ & $\begin{array}{l}\text { Month } \\
5\end{array}$ & $\begin{array}{l}\text { Month } \\
6\end{array}$ & $\begin{array}{l}\text { Month } \\
7\end{array}$ & $\begin{array}{l}\text { Month } \\
8\end{array}$ & $\begin{array}{l}\text { Month } \\
9\end{array}$ & $\begin{array}{l}\text { Month } \\
10\end{array}$ & $\begin{array}{l}\text { Month } \\
11\end{array}$ & $\begin{array}{c}\text { Month } \\
12\end{array}$ \\
\hline $\begin{array}{l}\text { Application of the experimental protocol to } \\
\text { Italian legislation on animal experimentation. }\end{array}$ & & & & & & & & & & & & \\
\hline $\begin{array}{l}\text { Follow the experiments performed in the } \\
\text { laboratory, and train to synaptosome analysis. }\end{array}$ & & & & & & & & & & & & \\
\hline SG1 & & & & & & & & & & & & \\
\hline SG2 & & & & & & & & & & & & \\
\hline $\begin{array}{l}\text { Report write to FAPESP and manuscript } \\
\text { preparation to publication. }\end{array}$ & & & & & & & & & & & & \\
\hline
\end{tabular}




\section{BIBLIOGRAPHIC REFERENCES}

Asukai, N. (2013). [Treatment of posttraumatic stress disorder and extinction learning of traumatic memory]. Nihon Shinkei Seishin Yakurigaku Zasshi 33, 111-115.

Bentz, D., Michael, T., Wilhelm, F.H., Hartmann, F.R., Kunz, S., von Rohr, I.R.R., and de Quervain, D.J.-F. (2013). Influence of stress on fear memory processes in an aversive differential conditioning paradigm in humans. Psychoneuroendocrinology 38, 1186-1197.

Berlau, D., and Mcgaugh, J. (2006). Enhancement of extinction memory consolidation: The role of the noradrenergic and GABAergic systems within the basolateral amygdala. Neurobiol. Learn. Mem. 86, 123-132.

Brewin, C.R., and Holmes, E.A. (2003). Psychological theories of posttraumatic stress disorder. Clin. Psychol. Rev. 23, 339-376.

Cahill, L., and McGaugh, J.L. (1996). Modulation of memory storage. Curr. Opin. Neurobiol. 6, 237-242.

Domingos, L.B., Hott, S.C., Terzian, A.L.B., and Resstel, L.B.M. (2017). P2X7 purinergic receptors participate in the expression and extinction processes of contextual fear conditioning memory in mice. Neuropharmacology.

Ferreira-Junior, N.C., Fedoce, A.G., Alves, F.H.F., and Resstel, L.B.M. (2013). Medial prefrontal cortex N-methyl-D-aspartate receptor/nitric oxide/cyclic guanosine monophosphate pathway modulates both tachycardic and bradycardic baroreflex responses. J. Neurosci. Res. 91, 1338-1348.

Fiorenza, N.G., Sartor, D., Myskiw, J.C., and Izquierdo, I. (2011). Treatment of fear memories: interactions between extinction and reconsolidation. An. Acad. Bras. Ciênc. 83, 1363-1372.

Fiorenza, N.G., Rosa, J., Izquierdo, I., and Myskiw, J.C. (2012). Modulation of the extinction of two different fear-motivated tasks in three distinct brain areas. Behav. Brain Res. 232, 210 216.

Fitzgerald, P.J., Seemann, J.R., and Maren, S. (2013). Can fear extinction be enhanced? A review of pharmacological and behavioral findings. Brain Res. Bull. 105, 46-60.

Fukushima, H., Zhang, Y., Archbold, G., Ishikawa, R., Nader, K., and Kida, S. (2014). Enhancement of fear memory by retrieval through reconsolidation. eLife 3, e02736.

Furini, C.R.G., Myskiw, J.C., Benetti, F., and Izquierdo, I. (2013). New frontiers in the study of memory mechanisms. Rev. Bras. Psiquiatr. 35, 173-177.

Gourley, S.L., Kedves, A.T., Olausson, P., and Taylor, J.R. (2009). A history of corticosterone exposure regulates fear extinction and cortical NR2B, GluR2/3, and BDNF. Neuropsychopharmacol. Off. Publ. Am. Coll. Neuropsychopharmacol. 34, 707-716.

van Haarst, A.D., Oitzl, M.S., and de Kloet, E.R. (1997). Facilitation of feedback inhibition through blockade of glucocorticoid receptors in the hippocampus. Neurochem. Res. 22, $1323-$ 1328. 
Han, F., Ding, J., and Shi, Y. (2014). Expression of amygdala mineralocorticoid receptor and glucocorticoid receptor in the single-prolonged stress rats. BMC Neurosci. 15, 77.

Hott, S.C., Gomes, F.V., Uliana, D.L., Vale, G.T., Tirapelli, C.R., and Resstel, L.B.M. (2017). Bed nucleus of the stria terminalis NMDA receptors and nitric oxide modulate contextual fear conditioning in rats. Neuropharmacology 112, 135-143.

Hübner, C., Bosch, D., Gall, A., Lüthi, A., and Ehrlich, I. (2014). Ex vivo dissection of optogenetically activated mPFC and hippocampal inputs to neurons in the basolateral amygdala: implications for fear and emotional memory. Front. Behav. Neurosci. 8, 64 .

Izquierdo, A. (2006). Brief Uncontrollable Stress Causes Dendritic Retraction in Infralimbic Cortex and Resistance to Fear Extinction in Mice. J. Neurosci. 26, 5733-5738.

Izquierdo, I. (2002). Memória Iván Izquierdo. (Porto Alegre: ARTMED).

Izquierdo, I., Furini, C.R.G., and Myskiw, J.C. (2016). Fear Memory. Physiol. Rev. 96, 695750.

Kaplan, G.B., and Moore, K.A. (2011). The use of cognitive enhancers in animal models of fear extinction. Pharmacol. Biochem. Behav. 99, 217-228.

de Kloet, E.R. (2000). Stress in the brain. Eur. J. Pharmacol. 405, 187-198.

de Kloet, E.R. (2014). From receptor balance to rational glucocorticoid therapy. Endocrinology $155,2754-2769$.

Klok, M.D., Alt, S.R., Irurzun Lafitte, A.J.M., Turner, J.D., Lakke, E.A.J.F., Huitinga, I., Muller, C.P., Zitman, F.G., de Kloet, E.R., and Derijk, R.H. (2011). Decreased expression of mineralocorticoid receptor mRNA and its splice variants in postmortem brain regions of patients with major depressive disorder. J. Psychiatr. Res. 45, 871-878.

Knox, D., Nault, T., Henderson, C., and Liberzon, I. (2012). Glucocorticoid receptors and extinction retention deficits in the single prolonged stress model. Neuroscience 223, 163-173.

Kolb, B., Whishaw, I.Q., and Teskey, G.C. (2016). An introduction to brain and behavior (New York: Worth Publishers/Macmillan Learning).

Kolber, B.J., Wieczorek, L., and Muglia, L.J. (2008). Hypothalamic-pituitary-adrenal axis dysregulation and behavioral analysis of mouse mutants with altered glucocorticoid or mineralocorticoid receptor function. Stress Amst. Neth. 11, 321-338.

Lass-Hennemann, J., and Michael, T. (2014). Endogenous cortisol levels influence exposure therapy in spider phobia. Behav. Res. Ther. 60, 39-45.

LeDoux, J.E. (2000). Emotion circuits in the brain. Annu. Rev. Neurosci. 23, 155-184.

Lemos, J.I., Resstel, L.B., and Guimarães, F.S. (2010). Involvement of the prelimbic prefrontal cortex on cannabidiol-induced attenuation of contextual conditioned fear in rats. Behav. Brain Res. 207, 105-111. 
Leuner, B., and Gould, E. (2010). Dendritic Growth in Medial Prefrontal Cortex and Cognitive Flexibility Are Enhanced during the Postpartum Period. J. Neurosci. 30, 13499-13503.

Lisboa, S.F., Stecchini, M.F., Corrêa, F.M.A., Guimarães, F.S., and Resstel, L.B.M. (2010). Different role of the ventral medial prefrontal cortex on modulation of innate and associative learned fear. Neuroscience 171, 760-768.

Lonsdorf, T.B., Haaker, J., and Kalisch, R. (2014). Long-term expression of human contextual fear and extinction memories involves amygdala, hippocampus and ventromedial prefrontal cortex: a reinstatement study in two independent samples. Soc. Cogn. Affect. Neurosci. 9, 1973-1983.

Lu, Y.-L., and Richardson, H.N. (2014). Alcohol, stress hormones, and the prefrontal cortex: A proposed pathway to the dark side of addiction. Neuroscience.

Maren, S., Phan, K.L., and Liberzon, I. (2013). The contextual brain: implications for fear conditioning, extinction and psychopathology. Nat. Rev. Neurosci. 14, 417-428.

McKlveen, J.M., Myers, B., Flak, J.N., Bundzikova, J., Solomon, M.B., Seroogy, K.B., and Herman, J.P. (2013). Role of Prefrontal Cortex Glucocorticoid Receptors in Stress and Emotion. Biol. Psychiatry 74, 672-679.

Milad, M.R., and Quirk, G.J. (2012). Fear Extinction as a Model for Translational Neuroscience: Ten Years of Progress. Annu. Rev. Psychol. 63, 129-151.

Mizoguchi, K., Ikeda, R., Shoji, H., Tanaka, Y., Maruyama, W., and Tabira, T. (2009). Aging attenuates glucocorticoid negative feedback in rat brain. Neuroscience 159, 259-270.

Moench, K.M., and Wellman, C.L. (2014). Stress-induced alterations in prefrontal dendritic spines: Implications for post-traumatic stress disorder. Neurosci. Lett.

Morrison, F.G., and Ressler, K.J. (2014). From the neurobiology of extinction to improved clinical treatments. Depress. Anxiety 31, 279-290.

Mueller, D., and Cahill, S.P. (2010). Noradrenergic modulation of extinction learning and exposure therapy. Behav. Brain Res. 208, 1-11.

Mueller, D., Porter, J.T., and Quirk, G.J. (2008). Noradrenergic Signaling in Infralimbic Cortex Increases Cell Excitability and Strengthens Memory for Fear Extinction. J. Neurosci. 28, 369375.

Musazzi, L., Tornese, P., Sala, N., and Popoli, M. (2017). Acute or Chronic? A Stressful Question. Trends Neurosci. 40, 525-535.

Myers, B., McKlveen, J.M., and Herman, J.P. (2014). Glucocorticoid actions on synapses, circuits, and behavior: implications for the energetics of stress. Front. Neuroendocrinol. 35, 180-196.

Orsini, C.A., and Maren, S. (2012). Neural and cellular mechanisms of fear and extinction memory formation. Neurosci. Biobehav. Rev. 36, 1773-1802.

Pizzorusso, T. (2009). Neuroscience. Erasing fear memories. Science 325, 1214-1215. 
Popoli, M., Yan, Z., McEwen, B.S., and Sanacora, G. (2012). The stressed synapse: the impact of stress and glucocorticoids on glutamate transmission. Nat. Rev. Neurosci. 13, 22-37.

Qi, X.-R., Kamphuis, W., Wang, S., Wang, Q., Lucassen, P.J., Zhou, J.-N., and Swaab, D.F. (2013). Aberrant stress hormone receptor balance in the human prefrontal cortex and hypothalamic paraventricular nucleus of depressed patients. Psychoneuroendocrinology 38 , 863-870.

Raio, C.M., Brignoni-Perez, E., Goldman, R., and Phelps, E.A. (2014). Acute stress impairs the retrieval of extinction memory in humans. Neurobiol. Learn. Mem. 112, 212-221.

Rescorla, R.A. (2004). Spontaneous recovery varies inversely with the training-extinction interval. Learn. Behav. 32, 401-408.

Resstel, L.B.M., and Corrêa, F.M.A. (2006). Involvement of the medial prefrontal cortex in central cardiovascular modulation in the rat. Auton. Neurosci. Basic Clin. 126-127, 130-138.

Roesler, R., and Schröder, N. (2011). Cognitive enhancers: Focus on modulatory signaling influencing memory consolidation. Pharmacol. Biochem. Behav. 99, 155-163.

Ryan, B., Musazzi, L., Mallei, A., Tardito, D., Gruber, S.H.M., El Khoury, A., Anwyl, R., Racagni, G., Mathé, A.A., Rowan, M.J., et al. (2009). Remodelling by early-life stress of NMDA receptor-dependent synaptic plasticity in a gene-environment rat model of depression. Int. J. Neuropsychopharmacol. 12, 553-559.

Santini, E. (2004). Consolidation of Fear Extinction Requires Protein Synthesis in the Medial Prefrontal Cortex. J. Neurosci. 24, 5704-5710.

Schiller, D., Kanen, J.W., LeDoux, J.E., Monfils, M.-H., and Phelps, E.A. (2013). Extinction during reconsolidation of threat memory diminishes prefrontal cortex involvement. Proc. Natl. Acad. Sci. 110, 20040-20045.

Singewald, N., Schmuckermair, C., Whittle, N., Holmes, A., and Ressler, K.J. (2014). Pharmacology of cognitive enhancers for exposure-based therapy of fear, anxiety and traumarelated disorders. Pharmacol. Ther.

Solomon, M.B., Wulsin, A.C., Rice, T., Wick, D., Myers, B., McKlveen, J., Flak, J.N., UlrichLai, Y., and Herman, J.P. (2014). The selective glucocorticoid receptor antagonist CORT 108297 decreases neuroendocrine stress responses and immobility in the forced swim test. Horm. Behav. 65, 363-371.

Spiacci, G.B.L., Antero, L.S., Reis, D.G., Lisboa, S.F., and Resstel, L.B. (2016). Dorsal hippocampus cannabinoid type 1 receptors modulate the expression of contextual fear conditioning in rats: Involvement of local glutamatergic/nitrergic and GABAergic neurotransmissions. Eur. Neuropsychopharmacol. J. Eur. Coll. Neuropsychopharmacol. 26, $1579-1589$.

Treccani, G., Musazzi, L., Perego, C., Milanese, M., Nava, N., Bonifacino, T., Lamanna, J., Malgaroli, A., Drago, F., Racagni, G., et al. (2014). Stress and corticosterone increase the readily releasable pool of glutamate vesicles in synaptic terminals of prefrontal and frontal cortex. Mol. Psychiatry 19, 433-443. 
Uliana, D.L., Hott, S.C., Lisboa, S.F., and Resstel, L.B.M. (2016). Dorsolateral periaqueductal gray matter CB1 and TRPV1 receptors exert opposite modulation on expression of contextual fear conditioning. Neuropharmacology 103, 257-269.

VanElzakker, M.B., Kathryn Dahlgren, M., Caroline Davis, F., Dubois, S., and Shin, L.M. (2014). From Pavlov to PTSD: The extinction of conditioned fear in rodents, humans, and anxiety disorders. Neurobiol. Learn. Mem. 113, 3-18.

Wichert, S., Wolf, O.T., and Schwabe, L. (2013). Changing memories after reactivation: a onetime opportunity? Neurobiol. Learn. Mem. 99, 38-49.

Xing, G.-Q., Russell, S., Webster, M.J., and Post, R.M. (2004). Decreased expression of mineralocorticoid receptor mRNA in the prefrontal cortex in schizophrenia and bipolar disorder. Int. J. Neuropsychopharmacol. Off. Sci. J. Coll. Int. Neuropsychopharmacol. CINP 7, $143-153$. 
ANEXO XI - Ata de Defesa

Universidade de São Paulo

Ianus
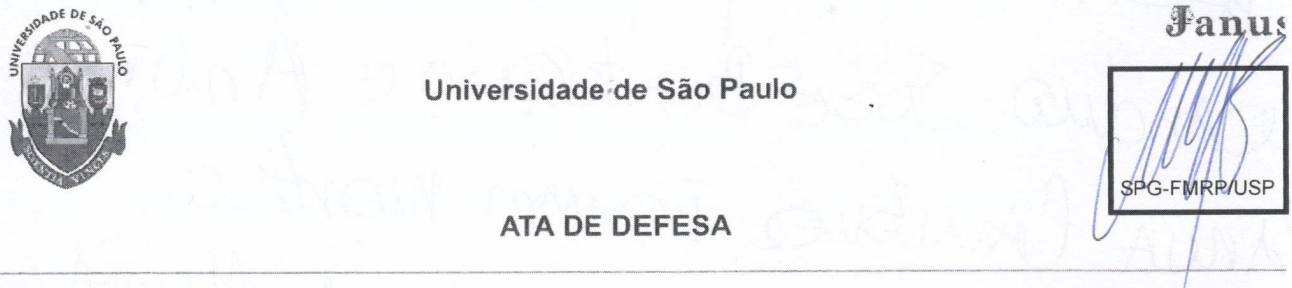

ATA DE DEFESA

Aluno: 17133 - $7374720-1 /$ Página 1 de 1

Ata de defesa de Tese do(a) Senhor(a) Jessica Rosa no Programa: Ciências Biológicas (Farmacologia), do(a) Faculdade de Medicina de Ribeirão Preto da Universidade de São Paulo.

Aos 07 dias do mês de março de 2019, no(a) FMRP/USP realizou-se a Defesa da Tese do(a) Senhor(a) Jessica Rosa, apresentada para a obtenção do título de Doutora intitulada:

"Os efeitos sustentados do estresse agudo sobre o processo de extinção da memória de medo condicionado contextual: participação dos receptores glicocorticoides no córtex pré-frontal"

Após declarada aberta a sessão, o(a) Sr(a) Presidente passa a palavra ao candidato para exposição e a seguir aos examinadores para as devidas arguições que se desenvolvem nos termos regimentais. Em seguida, a Comissão Julgadora proclama o resultado:

$\begin{array}{lll}\text { Nome dos Participantes da Banca } & \text { Função } & \text { Sigla da CPG Resultado } \\ \text { Leonardo Resstel Barbosa Moraes } & \text { Presidente FMRP - USP } \\ \text { Francisco Silveira Guimarães } & \text { Titular } & \text { FMRP - USP } \\ \text { Antonio de Pádua Carobrez } & \text { Titular } & \text { UFSC - Externo } \\ \text { Norberto Garcia Cairasco } & \text { Titular } & \text { FMRP - USP } \\ \text { Leandro José Bertoglio } & \text { Titular } & \text { UFSC - Externo }\end{array}$

Resultado Final: Aravely

Parecer da Comiśsã Julgadora * , lavrej a presente ata, que assino juntamente com os(as) Senhores(as). Ribeirăb preto, aos 07 dias do mês de marçode 2019.

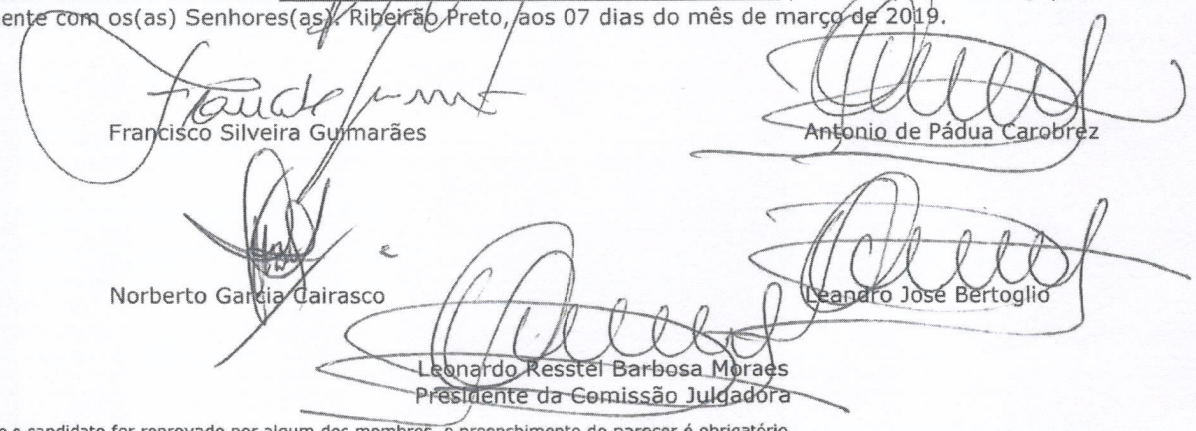

* Obs: Se o candidato for reprovado por algum dos membros, o preenchimento do parecer é obrigatório.

A defeşa foi homologada pela Comissão de)Pós-Graduação em $/ / 10 / 19$ e, portanto, o(a) aluno(a)

jus ao título de Doutơta em Ciências obtido no Programa Ciências Biológicas (Farmacologia) - Área de concęntraçãg: Farmacologia.

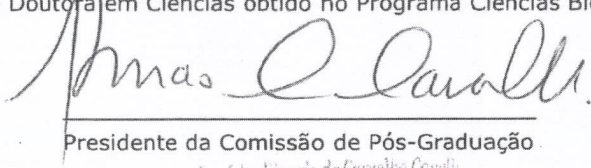

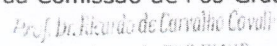

